\title{
Huts and stone arrangements at Hilary Creek, western Queensland: Recent fieldwork at an Australian Aboriginal site complex
}

\author{
Lynley A. Wallis, ${ }^{\mathrm{a}, \mathrm{b}}{ }^{*}$, Bryce Barker $^{\mathrm{c}}$, Heather Burke ${ }^{\mathrm{d}}$, Mia Dardengo ${ }^{\mathrm{a}, \mathrm{b}}$, Robert Jansen ${ }^{\mathrm{e}}$, \\ Dennis Melvillef ${ }^{\mathrm{f}}$, Geoffrey Jacks ${ }^{\mathrm{f}}$, Anthony Pagels ${ }^{\mathrm{d}}$, Andrew Schaefer ${ }^{\mathrm{b}, \mathrm{d}}$ and Iain Davidson ${ }^{\mathrm{g}}$ \\ ${ }^{a}$ Griffith Centre for Social and Cultural Research, Griffith University, 170 Kessels Road, Nathan, QLD 4111, Australia; \\ ${ }^{\mathrm{b}}$ Wallis Heritage Consulting, PO Box 300, Albany DC, WA 6331, Australia; ${ }^{\mathrm{c}}$ Institute of Resilient Regions, School of \\ Arts and Communication, University of Southern Queensland, Toowoomba, QLD 4350, Australia; ${ }^{\mathrm{d}}$ College of \\ Humanities, Arts and Social Sciences, Flinders University, GPO Box 2100, Adelaide, SA 5001, Australia; ${ }^{\mathrm{e}}$ Marion \\ Downs Station, C/- Boulia Post Office, QLD 4829, Australia; ${ }^{\mathrm{f}}$ Pitta Pitta Aboriginal Corporation, C/- Michael Owens \\ Lawyer and Consultant, 15 Cahill Street, Aitkenvale, QLD 4814 Australia; ${ }^{\mathrm{g}}$ School of Humanities, University of New \\ England, Armidale, NSW 2351, Australia \\ * Corresponding author 1.wallis@griffith.edu.au
}

\begin{abstract}
This paper reports on an Aboriginal site complex, incorporating hut structures, ceremonial stone arrangements, an extensive surface artefact assemblage of lithics and mussel shell, and a silcrete quarry, located along Hilary Creek, a tributary of the Georgina River in western Queensland, Australia. At least two phases of occupation are indicated. The most recent huts have their collapsed organic superstructure still present, while those of a presumably earlier phase are distinguished as bare, circular patches of earth which are conspicuous amongst the ubiquitous gibber, with or without stone bases, and lacking any collapsed superstructure. Immediately adjacent to the huts and also a few hundred metres away are clusters of small stone arrangements, and about $2 \mathrm{~km}$ to the southwest, along the same creekline, is another series of larger, more substantial stone arrangements; these features speak to the importance of the general Hilary Creek area for ceremonial purposes. Radiocarbon dating reveals use of the Hilary Creek complex dates to at least 300 years ago; the absence of any European materials suggests it was likely not used, or only used very sporadically, after the 1870 s when pastoralists arrived in the area, and when traditional lifeways were devastated by colonial violence.
\end{abstract}

\section{Introduction}

Perhaps because it lacks the romantic allure of the desert proper and typically does not possess rockshelters containing deep sedimentary sequences, far western Queensland has only sporadically drawn archaeological attention (e.g. Artym 2018; Barton 2001; Border and Rowland 1990; Davidson 1983, 2008; Davidson et al. 1989, 1991, 2004, 2005, 2018, 2020; Hiscock 1988). Nevertheless, the archaeological record of this dynamic landscape is extensive. In particular, wooden 'gunyahs' (variously known as 'wurleys' or huts), sometimes with stone foundations, represent a local site feature that can oftentimes be absolutely dated and provide an opportunity to recover in situ stratified materials (e.g. Kelly 1968:563; Robins 1981). Such sites also offer the potential to more closely examine the complexity of late Holocene Aboriginal lifeways and culture.

In an example of the growing interest in late Holocene technologies, Memmott (2007) explored architectural traditions, providing an Australia-wide overview of Aboriginal built structures such as the huts of western Queensland. Others have substantially expanded on Memmott's work. For example, Wallis and Matthews (2016) considered built stone structures inside rockshelters of the Pilbara region of Western Australia, McDonald and Berry (2017) reported on stone huts on islands off the Pilbara coastline and McNiven et al. (2017) reported on an Aboriginal stone house in southwest Victoria. Recently in Queensland Kreij et al. (2018) have explored stone fish traps in the Gulf of Carpentaria, Fitzpatrick et al. (2018) have investigated stone arrangements on Lizard Island and Barker et al. (2016) have documented stone arrangements on Mine Island. In this same vein, Wallis et al. (2017) reported on huts near the
Marion Downs Station airstrip, about $60 \mathrm{~km}$ southwest of the township of Boulia in the traditional lands of the Pitta-Pitta people. Initially documented by Davidson et al. (1989), these circular structures all have substantial bases of stones and sometimes their interiors retain elements of collapsed wooden superstructure. They were argued by Wallis et al. (2017) to have been domestic structures built by Aboriginal people to a deliberate pattern, being positioned to afford protection from inclement weather.

Beyond huts with stone foundations, stone arrangements are another form of Aboriginal construction which have long held fascination for Europeans observers and researchers. In the absence of historical records relating to their use and the difficulty in dating them directly, documentation of such sites tends to be largely descriptive (e.g. Barker et al. 2016; Duncan-Kemp 1952; Fitzpatrick et al. 2018; Greer et al. 2015; Hook et al. 2010; Howitt 1878; Law et al. 2017; McCarthy 1940; McConnel 1932; McIntyre-Tamwoy and Harrison 2004; McNiven 2016; Piotto et al. 2018; Ross 2008; Rowlands and Rowlands 1966a, 1966b; Spencer and Gillen 1901; Towle 1936; Wood Jones 1925); western Queensland is no different in this regard. Although ignored by Government Medical Officer (later appointed Northern Protector of Aboriginals) turned anthropologist Walter Roth (1897) and other early European observers, geomorphological surveys of the Boulia area in the 1960s noted stone arrangements as being a striking component of the local landscape (Reynolds 1964; Reynolds et al. 1961). Husband and wife team R.J. and J.M. Rowlands (1966a, 1966b, 1967, $1970,1972,1973,1976,1978,1980,1982,1985)$ subsequently spent two decades documenting such arrangements, though unfortunately their reports are now 


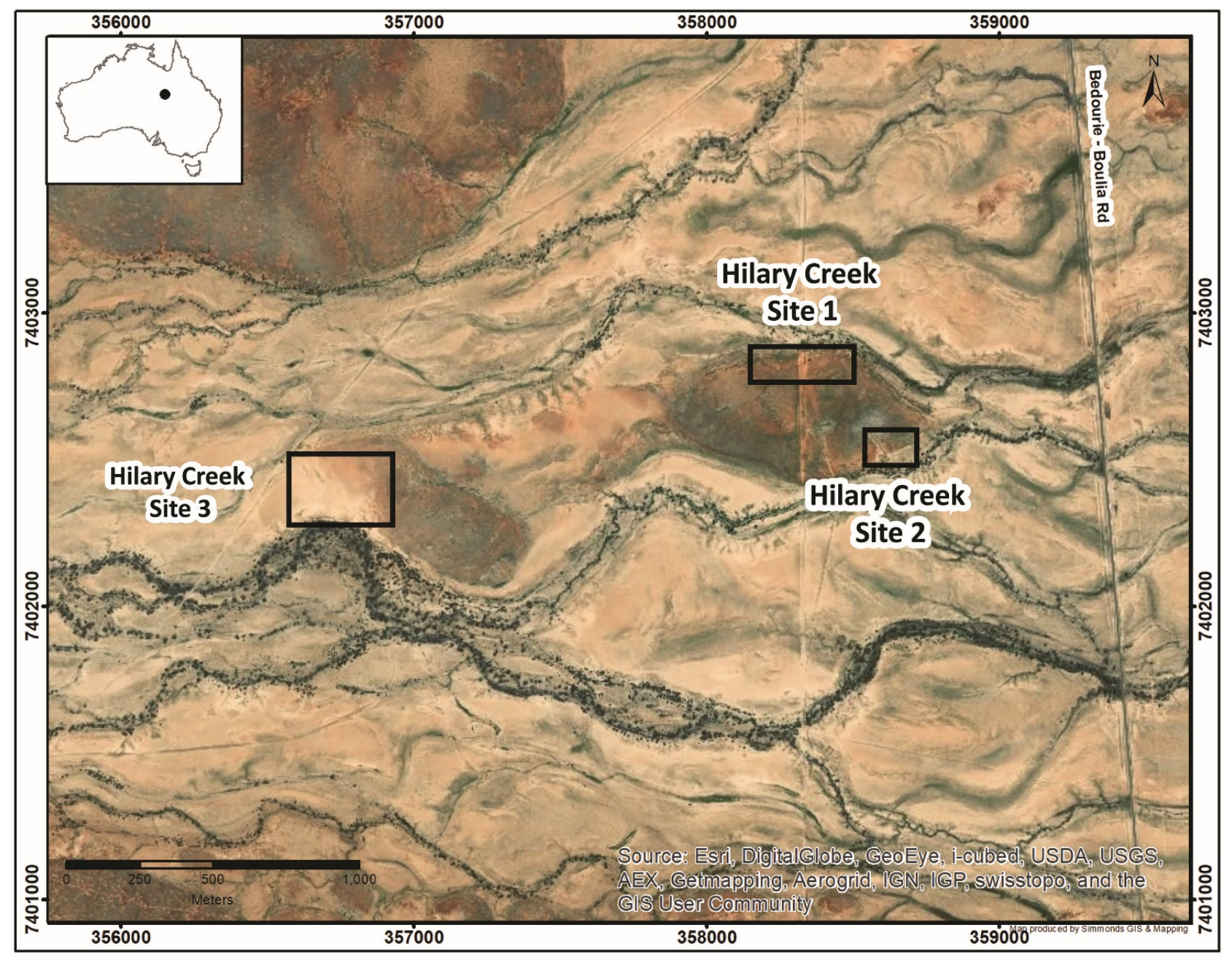

Figure 1 Map showing general location of the study area and the relationship between Hilary Creek Site 1 (HCS1), Hilary Creek Site 2 (HCS2) and Hilary Creek Site 3 (HCS3).

'closed access', making it difficult to gain a good understanding of the range and extent of such features beyond the generalisation that they are indeed abundant.

One area with congruence between stone huts and stone arrangements is Hilary Creek, a first order tributary of the Georgina River, located about $13 \mathrm{~km}$ southwest of the aforementioned Marion Downs Station airport huts (Figure 1). Davidson visited Hilary Creek in the 1980s and, while he completed some basic site plans and took photographs, his findings were not published. Another mention of the Hilary Creek complex, not by an archaeologist, was a report by Ritchie (1996), prepared for the North Australian Pastoral Company (NAPCo, the current owner of Marion Downs) to draw their attention to potential management issues at the locale. Ritchie's (1996) report was limited; in just six pages he reported on 13 sites, including sketches (though not photographs) of several stone arrangements. He noted only the most salient site features, which at Hilary Creek comprised,

11 old huts ... four of these old huts still have the sticks standing in them. They largely consist of a cleared area with a stone border around a stick shelter about $1 \mathrm{~m}$ high. There is evidence of some mussel shells around these huts (Ritchie 1996:5).
Ritchie's (1996:5) description of 'sticks standing' at the time of his visit appears to have been an exaggeration; at the time of Davidson's earlier visit branches were observed lying over the stones but none were still erect. While he did not make mention of features beyond the huts and mussel shell, Ritchie (1996:6) reported 'several stone arrangements located approximately $2 \mathrm{~km}$ back up Hilary Creek'. He also described extensive complex stone arrangements on numerous creek lines some $55 \mathrm{~km}$ to the northwest of Hilary Creek, as well as $30 \mathrm{~km}$ to the south at Breadalbane.

The authors of this paper documented the Hilary Creek site in 2017. We determined that the site was larger than previously recognised, more accurately described as a 'site complex', comprising huts, an extensive flaked and ground stone artefact assemblage, shell midden material, stone arrangements and a silcrete quarry. This paper details the recording, excavation and dating of the Hilary Creek huts, in addition to describing the associated stone arrangements in proximity to the huts, as well as those $2 \mathrm{~km}$ downstream. In doing so it provides some of the first absolute dates for Aboriginal architectural traditions in western Queensland. 


\section{The Study Area}

The Georgina River is the westernmost of the three major rivers running through the so-called Channel Country, joining with the Eyre River south of Marion Downs to flow into the Lake Eyre Basin. It has a low gradient and in periods of high rainfall has a large lateral spread via numerous tributaries contributing to the river's 'braided' water courses dispersed across the expansive plains of the region (Reynolds et al. 1961:7). Although Hilary Creek flows during heavy rain events, it is ephemeral and does not hold water for any extended period of time during the dry season; as such it would only have been suitable for occupation for short periods under certain conditions.

While the waterways themselves are associated with Quaternary alluvial sediments, more broadly the landscape is dominated by the silicified Tertiary Marion Formation, overlying a truncated laterite profile on the Lower Cretaceous Wilgunya Formation (Paten 1964:12; Reynolds 1964:5; Whitehouse 1948; Wilson 1990). Dissection and erosion of the Marion Formation has given rise to the stony 'gibber' plains that are characteristic of the region. Along with the silicified materials of the Marion Formation (which are highly suitable for stone artefact production), the rounded gibber rocks of the Wilgunya Formation, coated with iron oxide, are the source of the building material for the stone hut structures and arrangements described herein. Depending on the specific local conditions, reddish clay soils or black soils have developed, and in some areas longitudinal sand-dunes are present, though none occur in the immediate proximity of the study sites.

Pitta Pitta country straddles the Mitchell Grass Downs and Channel Country biogeographic regions, with an arid climate of hot summers and short winters. The mean monthly annual temperature is a low of $22.9^{\circ} \mathrm{C}$ in July and a high of $38.6^{\circ} \mathrm{C}$ in December, with overnight temperatures of single digits regularly in winter (BoM 2020; weather station No. 38003). The prevailing winds for most of the year are from the south and southwest. Being at the northeastern extent of the Simpson Desert, rainfall is highly unpredictable, with periods of low rainfall combined with high evaporation leading to regular periods of prolonged droughts and low surface water availability. Data collected at Marion Downs (BoM 2020; weather station No. 38014) indicate mean annual rainfall is just over $200 \mathrm{~mm}$, most of which falls during the summer months. In drought years there is $<40 \mathrm{~mm}$ of rain, though periodical extreme flooding events generate as much as 680 mm (Phelps et al. 2003; Popic and Wardle 2012:101).

As a result of the limited and unpredictable rainfall, the local vegetation is scant, comprising hummock and tussock grasslands, with some patches of acacia shrublands, acacia open woodlands and eucalypt woodlands (Alexander 2005). The main plaints are Mitchell grasses, gidgee, mulga, turkey bush and spinifex, all of which are able to survive drought periods. Portulaca and nardoo were particularly important food plants for local Aboriginal people (e.g. Hodgkinson 1877:510, 519; Wells 1893), with limited availability related to seasonal conditions.

The region supports a variety of native mammals, including red and eastern grey kangaroos, dingoes, wallabies, possums, bandicoots, rats, sugar-gliders and flying foxes (Strahan 1983). Numerous bird species and reptiles are also present, including emus, bustards, herons, kites, wedge-tailed eagles, doves and ducks, along with lizards and snakes. When full, major waterholes also support a range of freshwater fish species (e.g. Hodgkinson 1877:514, 518, 519; McKinlay 1861-1862:51, 69, 83, 91, 92, 107) and yabbies (a type of small crayfish), and early ethnohistorical accounts made reference to the widespread consumption of freshwater mussels (e.g. Hodgkinson 1877:510, 514, 522; Mackie 1901:133).

Exploratory European incursions into the Channel Country began with Burke and Wills' ill-fated 1860-1861 expedition (Anon. 1861; Wills 1861; see also McKinlay 1861-1862; Walker 1862), and continued more than a decade later with a Government-sponsored expedition led by William Hodgkinson in 1877 which encountered a group of 30-40 Aboriginal people about $100 \mathrm{~km}$ east of Hilary Creek. Although he mentioned the presence of "large, well beaten and numerous' native paths (Hodgkinson 1877:515), he did not describe any stone arrangements; we discuss his descriptions of Aboriginal dwellings in the Discussion section of this paper.

Permanent European settlement followed the introduction of the Pastoral Leases Act 1869, which made financial investment in the region more attractive (Pearson and Lennon 2010:99). Several 'runs' (cattle stations) were established on the Burke River (which runs into the Georgina River) and its tributaries in 1876, including Monkira, Marion Downs, Glenormiston and Glengyle, followed by Sandringham and Herbert Downs the following year. Although explorers' interactions with Aboriginal people had been sporadic and largely non-confrontational, pastoralists took a different approach, bolstered by the sanguinary actions of the Native Mounted Police (NMP) (Burke and Wallis 2019; Richards 2008). The first NMP camp in proximity to Marion Downs was established in 1876 some $\sim 350 \mathrm{~km}$ to the east on the Diamantina River (Western Champion, 24 February 1882, p.2), followed in 1878 by a second camp on the Burke River just $90 \mathrm{~km}$ northeast of Marion Downs (Queenslander, 18 January 1879 , p.70). Given their well-documented propensity for 'dispersing' (i.e. killing) Aboriginal people, the presence of the NMP at Diamantina and Burke River is a strong indication that violent confrontations had become the norm in the region after the permanent arrival of pastoralists. Roth (1897:41) used the term 'annihilated' to describe the local people just two decades after the establishment of the first runs in the district; we return to this issue when discussing the cessation of use of the Hilary Creek complex.

\section{Methods}

Systematic pedestrian survey was carried out over the entire Hilary Creek site, with a Nikon total station used to record all features. Aerial photography was taken using a DJI Phantom 4 Pro drone, and line drawings were made of all features using the aerial imagery as a base plan. Photographs and line drawings of features were georectified and collated in ArcGIS.

Recording of the huts included such attributes as diameter (typically inner diameter to ensure consistency), number of stones, stone raw material types, presence/absence and extent of superstructure, associated material culture, and the direction of the hut opening (if applicable). Huts were allocated to a type as follows:

- $\quad$ Type 1 = Collapsed wooden superstructure present, a central circular area generally clear of any rocks 
(including gibber stones), and a tightly structured circumference of larger foundational stones.

- $\quad$ Type 2 = No wooden superstructure, a central circular area generally clear of any rocks (including gibber stones), and a diffuse circumference of larger foundation stones.

- $\quad$ Type 3 = No wooden superstructure, a central circular area generally clear of any rocks (including gibber stones), and lacking any circumference of larger foundation stones.

Test-pits measuring $100 \times 100 \mathrm{~cm}$ were excavated inside Hut 1 and outside Hut 5. Assuming that the superstructure of these huts may have been replaced or repaired through time, it was hoped that excavated cultural material would give an indication of when they were first used compared to more recent estimates from dating the collapsed architectural wood. Excavation proceeded in arbitrary units (XUs) unless a stratigraphic feature was encountered. Sediment samples were taken from each $\mathrm{XU}$, at which time colours were determined through reference to Munsell Soil Color ${ }^{\circledR}$ Charts and $\mathrm{pH}$ values through a colorimetric test. Where possible, in situ charcoal samples were collected and their exact locations and depths recorded. All excavated sediment was passed through 3 and $6 \mathrm{~mm}$ nested sieves, and all cultural material in the sieves retained for laboratory analysis. Following excavation, stratigraphic sections were cleaned back, drawn and photographed.

Samples of gidgee (Acacia cambagei) from the interior surfaces of several huts were collected for conventional analysis at the University of Waikato Radiocarbon Dating Laboratory. Although gidgee can be a long-lived species, we attempted to alleviate the 'old wood problem' by selecting samples from the exterior of smaller branches. Mussel shells were also collected from excavations for dating. Visual inspection (for cracking across growth rings or softening/powdering of shell surface) and Feigl staining for recrystallisation (Friedman 1959) demonstrated all dated mussel shell samples were aragonite. All radiocarbon ages were calibrated using OxCal (version 4.3.2) (Bronk Ramsey 2017) using the SHCAL13 dataset (Reimer et al. 2013). There has been limited research into the reservoir effect in western Queensland and so we were not able to specifically adjust for this issue. However, the local geology is non-carbonate fluvial/alluvial sediments and thus any potential riverine reservoir effect for the freshwater mussel shells should be negligible.

The stone arrangements were photographed both obliquely and in plan view, and then categorised following the non-figurative type categories of Fitzpatrick et al. (2018).

Given the large size of the surface flaked stone assemblage, it was not feasible or culturally appropriate to collect all such artefacts. Beyond the artefacts in the excavation squares, a random sampling strategy was adopted, with all surface artefacts salvaged from three 1 x $1 \mathrm{~m}$ squares positioned amid the huts, one $1 \times 1 \mathrm{~m}$ square positioned a short distance towards the silcrete quarry, west of the fenceline dissecting the site, and one $0.5 \times 0.5 \mathrm{~m}$ square in the quarry itself. Analysis of the flaked stone assemblage is being undertaken by Dr Tim Maloney and results will be reported elsewhere. For each grinding stone, a maximum length, width and thickness were recorded, along with a weight. The raw material and number of ground surfaces per object were recorded, and a determination made as to whether the piece was a pestle (top stone) or mortar (base stone).

\section{Results}

The Hilary Creek site complex consists of three main areas: Hilary Creek Site 1 (HCS1) and Hilary Creek Site 3 (HCS3), both of which included artefacts, huts and stone arrangements positioned in relatively close proximity on opposite sides of the same gibber exposure, and Hilary Creek Site 2 (HCS2) comprising only stone arrangements and located about $1.8 \mathrm{~km}$ distant from the other two locales (Figure 1).

\section{HCS1}

In addition to a large surface assemblage of artefacts (see below) HCS1 comprises 16 hut structures spread over a 0.12 ha area (Figure 2). We assume that our identification of five additional huts to the 11 originally recorded by Ritchie (1996) is owing to our inclusion of structures lacking intact stone foundations and/or collapsed superstructure; in this we were greatly aided by the plan view of the site afforded by the drone. A station track and fenceline runs north-south cutting through HCS1, separating the huts and majority of stone arrangements on the east from a long linear and three small circular stone arrangements and silcrete quarry to the west. When the fence was constructed the presence of the latter features had not been recognised, hence it was positioned to avoid impacting the huts without realising that it essentially dissected the site.

Of the 16 huts at HCS1, four Type 1 huts were in excellent condition, retaining fragments of collapsed gidgee superstructure (Appendix A). Eight huts were categorised as Type 2, and the remaining four as Type 3. Towards the end of the fieldwork an additional three Type 2 huts were located $300 \mathrm{~m}$ to the southeast along another of the braided stream channels in the area labelled as HCS3; time constraints precluded these huts being recorded in detail (though they appeared, at least superficially, to be of similar forms and sizes to those documented at HCS1), though the stone arrangements at HCS3 were photographed and are described below.

Overall the Hilary Creek huts are of two different types: those with a c-shaped base of cobbles (Types 1 and 2), and those without any such base (Type 3). The cobbles presumably functioned to support the wooden superstructure, but in those without cobbles it is unclear whether this is because such stones have been removed through natural or cultural processes or were never present to begin with and the superstructure was not supported by a stone base. Regardless, all types had a central stone-free circular interior that averaged $3.2 \mathrm{~m}^{2}$ in area. The interior diameter of all stone lined huts is quite regular, measuring between $1-2.5 \mathrm{~m}$ (average $=2.0 \mathrm{~m}$ ), while the exterior diameter exhibits more variation owing to the sometimes dispersed nature of the stone foundation (3.2$6.8 \mathrm{~m}$, average $=4.2 \mathrm{~m}$ ). When present, foundation cobbles measured up to $30 \mathrm{~cm}$ in maximum dimension, a size small enough to be easily moved by a single individual but large enough not to be easily displaced by wind, water or native animals. Six hut foundations included large silcrete cores that appear to have been used opportunistically as structural components - the silcrete quarry $100 \mathrm{~m}$ to the west of the huts almost certainly being their source - while all other cobbles were locally available gibber stone. 


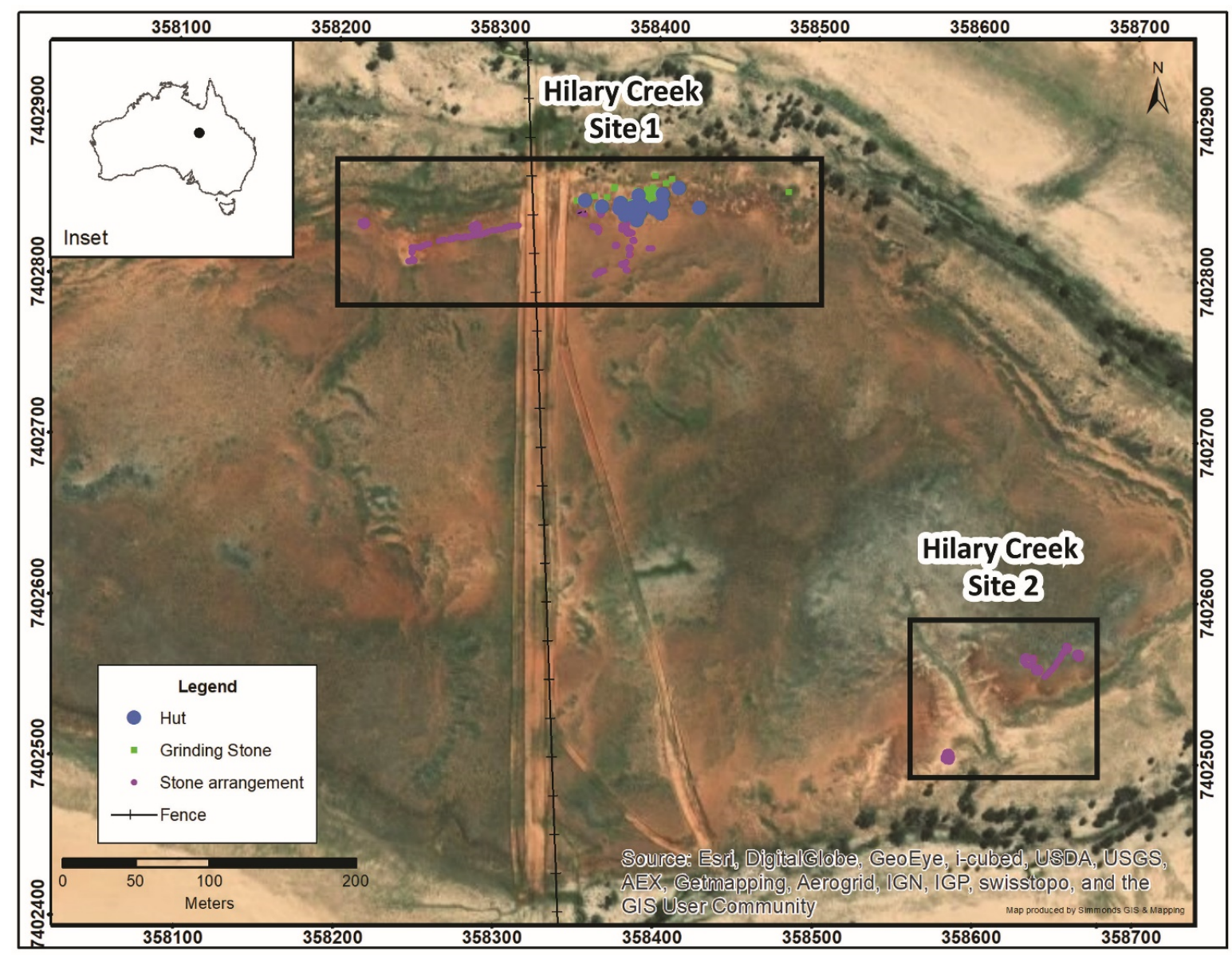

Figure 2. Detailed map showing HCS1 and HCS3 features.

Owing to the differing preservation conditions and the sometimes movement of cobbles from their original positions, only 10 of the huts possessed recognisable openings. These were regularly orientated between $294^{\circ}$ and $42^{\circ}$ (i.e. northwest and northeast), opposite to the prevailing wind direction, similar to the huts reported by Wallis et al. (2017) and in accordance with Hodgkinson's (1877) observations (see below).

\section{Surface Wood Sample Dating}

A total of 12 radiocarbon ages were obtained from several of the HCS1 huts: four from surface contexts and eight from excavated contexts (Table 1, Figure 3 ). Radiocarbon dating of the wood from the interior surface of Huts 3 and 4 yielded median dates of 114 and 179 cal BP, respectively, placing their most recent use in the decades preceding initial European incursion into the region. Likewise, the wood on the surface of Hut 1 gave a median age of $149 \mathrm{cal} \mathrm{BP}$, while that from Hut 5 gave a median age of $125 \mathrm{cal} \mathrm{BP}$; these two huts also produced older age estimates from their excavations (see below). Although these dates on wood and those from the surface relate to a median age falling just prior to European arrival into the region, the suite of dates taken as a whole overlap the period of European intrusion; a larger sample of surface dates and a more fine-grained chronological study is required in the future in order to ascertain a more accurate chronology.

\section{Excavations}

Hut 1 was located on a slightly raised mound towards the eastern extremity of the complex. It was well-preserved, with segments of gidgee deriving from the original superstructure still present on the surface (Figure 4). A single $1 \mathrm{x} 1 \mathrm{~m}$ test pit, Square A, was excavated in the approximate centre of Hut 1 , in an area that contained wood, some fragmentary mussel shell and two stone artefacts. It comprised two stratigraphic units (SUs; Figure 5). SU1 was a firm sediment (5YR 5/8 yellowish red) which extended to a maximum depth of $9.6 \mathrm{~cm}$, underlain by SU2, a more compact, harder sediment (5YR 4/6 yellowish red) extending to $29.4 \mathrm{~cm}$. Below this the sediment consisted of large, lumpy clay blocks that were extremely difficult to excavate and was culturally sterile.

Four age estimates were obtained from Hut 1 Square A (Table 1, Figure 3). Samples from shell and charcoal from XU4 returned median ages of 183 and 285 cal. BP, respectively, and a charcoal date from XU6 returned a date of 189 cal BP. A further date on shell from XU6 collected from the sieves dated to $278 \mathrm{cal} \mathrm{BP}$. It is clear from the dates that the shallow deposit, cracking nature of the clay-rich deposit and the restricted interior activity area of a small hut led to sediments mixing over time, with the oldest date -285 cal BP from XU4 - being similar in age to the near basal date of 278 cal BP from XU6. Overall, the entire suite of dates range from $149 \mathrm{cal} \mathrm{BP}$ on the surface to a maximum of $285 \mathrm{cal} \mathrm{BP}$ in XU4, representing a span of only 136 years. 
Table 1. List of radiocarbon dates associated with huts at HCS1.

\begin{tabular}{|c|c|c|c|c|c|c|c|c|}
\hline Hut No. & $\begin{array}{l}\text { Sample } \\
\text { ID }\end{array}$ & Material & Lab. No. & $\begin{array}{l}\delta^{13} \mathrm{C} \\
(\%)\end{array}$ & $\begin{array}{c}{ }^{14} \mathrm{C} \text { Age } \\
\text { (years BP) }\end{array}$ & $\begin{array}{c}\text { Calibrated Age BP } \\
(68.2 \% \text { Prob.) }\end{array}$ & $\begin{array}{c}\text { Calibrated Age BP } \\
\text { (95.4\% Prob.) }\end{array}$ & $\begin{array}{c}\text { Median Calibrated } \\
\text { Age BP }\end{array}$ \\
\hline \multirow{21}{*}{$\begin{array}{l}\text { Hut } 1 \\
\text { (interior) }\end{array}$} & \multirow{4}{*}{ Surface } & \multirow{4}{*}{ Wood } & \multirow{4}{*}{ Wk-47444 } & \multirow{4}{*}{$-24.5 \pm 0.5$} & \multirow{4}{*}{$145 \pm 25$} & $253-226(14.4 \%)$ & $264-221(20.3 \%)$ & \multirow{4}{*}{149} \\
\hline & & & & & & $142-133(4.8 \%)$ & $147(75.1 \%)$ & \\
\hline & & & & & & $122-57(32.3 \%)$ & & \\
\hline & & & & & & $33-0(16.7 \%)$ & & \\
\hline & \multirow{6}{*}{$\begin{array}{c}\mathrm{SqA} \\
\mathrm{XU} 4 \\
7.2 \mathrm{~cm}\end{array}$} & \multirow{6}{*}{ Shell } & \multirow{6}{*}{ Wk-47448 } & \multirow{6}{*}{ N/A } & \multirow{6}{*}{$175 \pm 20$} & $274-241(21.2 \%)$ & $279-205(38.1 \%)$ & \multirow{6}{*}{183} \\
\hline & & & & & & $230-215(8.9 \%)$ & $193-170(3.8 \%)$ & \\
\hline & & & & & & $152-139(7.9 \%)$ & $155-132(10.6 \%)$ & \\
\hline & & & & & & $114-103(5.7 \%)$ & $122-56(28.0 \%)$ & \\
\hline & & & & & & $93-71(12.1 \%)$ & $30(14.9 \%)$ & \\
\hline & & & & & & $22(12.3 \%)$ & & \\
\hline & \multirow{3}{*}{$\begin{array}{c}\mathrm{SqA} \\
\mathrm{XU} 4 \\
8.5 \mathrm{~cm}\end{array}$} & \multirow{3}{*}{ Charcoal } & \multirow{3}{*}{ Wk-47449 } & \multirow{3}{*}{ N/A } & \multirow{3}{*}{$230 \pm 16$} & $284-278(7.4 \%)$ & 294-273 (18.3\%) & \multirow{3}{*}{285} \\
\hline & & & & & & 208-179 (35.1\%) & 217-151 (77.1\%) & \\
\hline & & & & & & $172-154(25.6 \%)$ & & \\
\hline & \multirow{2}{*}{$\begin{array}{c}\text { SqA } \\
\text { XU6 } \\
25.5 \mathrm{~cm} \\
\end{array}$} & \multirow{2}{*}{ Shell } & \multirow{2}{*}{ Wk-47450 } & \multirow{2}{*}{ N/A } & \multirow{2}{*}{$227 \pm 20$} & $284-277(6.8 \%)$ & $296-270(19.5 \%)$ & \multirow{2}{*}{278} \\
\hline & & & & & & $210-153(61.4 \%)$ & $220-148(75.9 \%)$ & \\
\hline & \multirow{6}{*}{$\begin{array}{c}\text { SqA } \\
\text { XU6 } \\
16.5 \mathrm{~cm}\end{array}$} & \multirow{6}{*}{ Charcoal } & \multirow{6}{*}{ Wk-47451 } & \multirow{6}{*}{ N/A } & \multirow{6}{*}{$161 \pm 16$} & $261-240(15.3 \%)$ & $273-216(29.0 \%)$ & \multirow{6}{*}{189} \\
\hline & & & & & & $231-223(5.1 \%)$ & $150-131(8.5 \%)$ & \\
\hline & & & & & & $146-139(4.7 \%)$ & $124-56(36.9 \%)$ & \\
\hline & & & & & & $113-103(7.4 \% 0$ & $41(21.0 \%)$ & \\
\hline & & & & & & $95-70(17.4 \%)$ & & \\
\hline & & & & & & $23(18.3 \%)$ & & \\
\hline \multirow{4}{*}{ Hut 3} & & & & & & $240-230(6.2 \%)$ & 254-225 (13.0\%) & \\
\hline & $\mathrm{S}_{-1}$ & Wod t & WV1 1741 & 0260 & 11 & $139-113(19.6 \%)$ & $143(82.4 \%)$ & 11 \\
\hline & Suitace & 8000 & 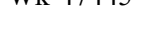 & $22.0 \pm 0.0$ & $110+20$ & $103-94(5.2 \%)$ & & 117 \\
\hline & & & & & & $71-22(37.2 \%)$ & & \\
\hline
\end{tabular}


Table 1. List of radiocarbon dates associated with huts at HCS1 (cont.).

\begin{tabular}{|c|c|c|c|c|c|c|c|c|}
\hline Hut No. & $\begin{array}{c}\text { Sample } \\
\text { ID }\end{array}$ & Material & Lab. No. & $\begin{array}{l}\delta^{13} \mathrm{C} \\
(\%)\end{array}$ & $\begin{array}{c}{ }^{14} \mathrm{C} \text { Age } \\
\text { (years BP) }\end{array}$ & $\begin{array}{c}\text { Calibrated Age BP } \\
(68.2 \% \text { Prob. }) \\
\end{array}$ & $\begin{array}{c}\text { Calibrated Age BP } \\
(95.4 \% \text { Prob. }) \\
\end{array}$ & $\begin{array}{c}\text { Median Calibrated } \\
\text { Age BP } \\
\end{array}$ \\
\hline \multirow{7}{*}{ Hut 4} & \multirow{7}{*}{ Surface } & \multirow{7}{*}{ Wood } & \multirow{7}{*}{ Wk-47446 } & \multirow{7}{*}{$-22.6 \pm 0.5$} & \multirow{7}{*}{$185 \pm 28$} & 279-243 (19.0\%) & $284-133(62.4 \%)$ & \multirow{7}{*}{179} \\
\hline & & & & & & 230-205 (12.3\%) & $122-57(21.6 \%)$ & \\
\hline & & & & & & $193-170(9.0 \%)$ & $30(11.5 \%)$ & \\
\hline & & & & & & $154-140(7.7 \%)$ & & \\
\hline & & & & & & $113-104(3.8 \%)$ & & \\
\hline & & & & & & $92-71(7.5 \%)$ & & \\
\hline & & & & & & $20(8.8 \%)$ & & \\
\hline \multirow{21}{*}{ Hut 5} & \multirow{4}{*}{ Surface } & \multirow{4}{*}{ Wood } & \multirow{4}{*}{ Wk-47447 } & \multirow{4}{*}{$-24.2 \pm 0.5$} & \multirow{4}{*}{$130 \pm 25$} & $243-230(8.4 \%)$ & $255-224(15.4 \%)$ & \multirow{4}{*}{125} \\
\hline & & & & & & $139-113(17.0 \%)$ & $144(80.0 \%)$ & \\
\hline & & & & & & $104-85(9.1 \%)$ & & \\
\hline & & & & & & $71-20(33.7 \%)$ & & \\
\hline & \multirow{5}{*}{$\begin{array}{c}\text { SqA } \\
\text { XU3c }\end{array}$} & \multirow{5}{*}{ Shell } & \multirow{5}{*}{ Wk-47452 } & \multirow{5}{*}{ N/A } & \multirow{5}{*}{$154 \pm 21$} & $255-238(10.2 \%)$ & $270-219(24.2 \%)$ & 181 \\
\hline & & & & & & $233-225(4.5 \%)$ & $149(71.2 \%)$ & \\
\hline & & & & & & $143-137(3.6 \%)$ & & \\
\hline & & & & & & $115-59(32.2 \%)$ & & \\
\hline & & & & & & $26(17.7 \%)$ & & \\
\hline & \multirow{6}{*}{$\begin{array}{c}\text { SqA } \\
\text { XU3c }\end{array}$} & \multirow{6}{*}{ Charcoal } & \multirow{6}{*}{ Wk-47453 } & \multirow{6}{*}{ N/A } & \multirow{6}{*}{$159 \pm 16$} & 259-239 (13.8\%) & $271-217(27.6 \%)$ & \multirow{6}{*}{189} \\
\hline & & & & & & $231-224(4.6 \%)$ & $150-132(8.2 \%)$ & \\
\hline & & & & & & $145-138(4.5 \%)$ & $124-56(37.8 \%)$ & \\
\hline & & & & & & $113-102(7.8 \%)$ & $41(21.8 \%)$ & \\
\hline & & & & & & $96-69(18.8 \%)$ & & \\
\hline & & & & & & $24(18.7 \%)$ & & \\
\hline & \multirow{2}{*}{$\begin{array}{l}\mathrm{SqA} \\
\mathrm{XU} 4\end{array}$} & \multirow{2}{*}{ Shell } & \multirow{2}{*}{ Wk-47454 } & \multirow{2}{*}{ N/A } & \multirow{2}{*}{$225 \pm 21$} & $283-277(5.9 \%)$ & $296-268(19.5 \%)$ & 105 \\
\hline & & & & & & $210-154(62.3 \%)$ & $220-147(75.9 \%)$ & 100 \\
\hline & & & & & & 279-265 (15.9\%) & $285-253(24.2 \%)$ & \\
\hline & $\mathrm{SqA}$ & Chorsol & whe & No & 00148 & $221-205(19.4 \%)$ & $227-142(71.2 \%)$ & \\
\hline & XU4 & Hate & VIN-4/FJ & IN/A & $201+10$ & $193-169(25.4 \%)$ & & 101 \\
\hline & & & & & & $154-147(7.5 \%)$ & & \\
\hline
\end{tabular}




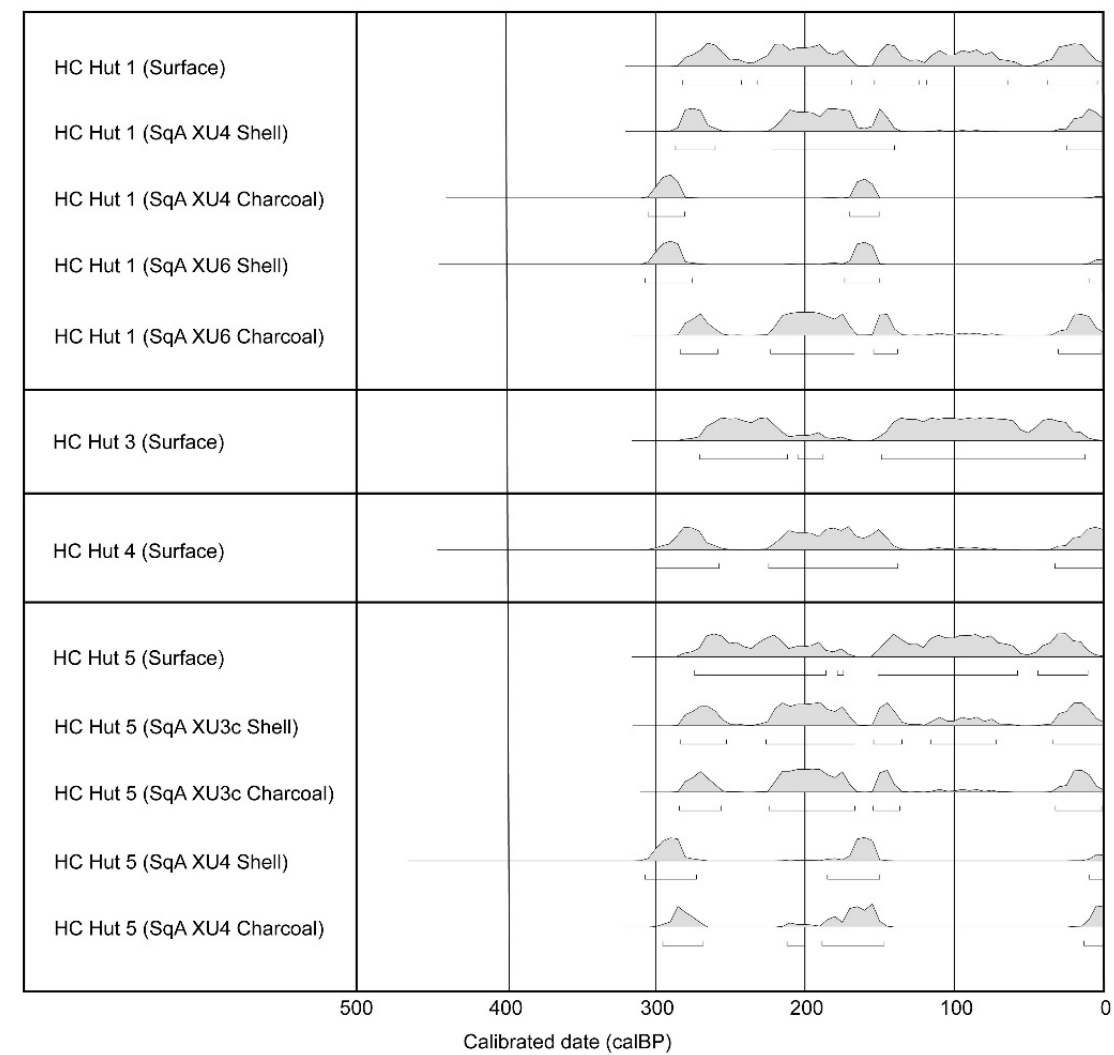

Figure 3. Radiocarbon dating results, calibrated using OxCal (version 4.3.2) (Bronk Ramsey 2017) using the SHCAL13 calibration dataset (Reimer et al. 2013).
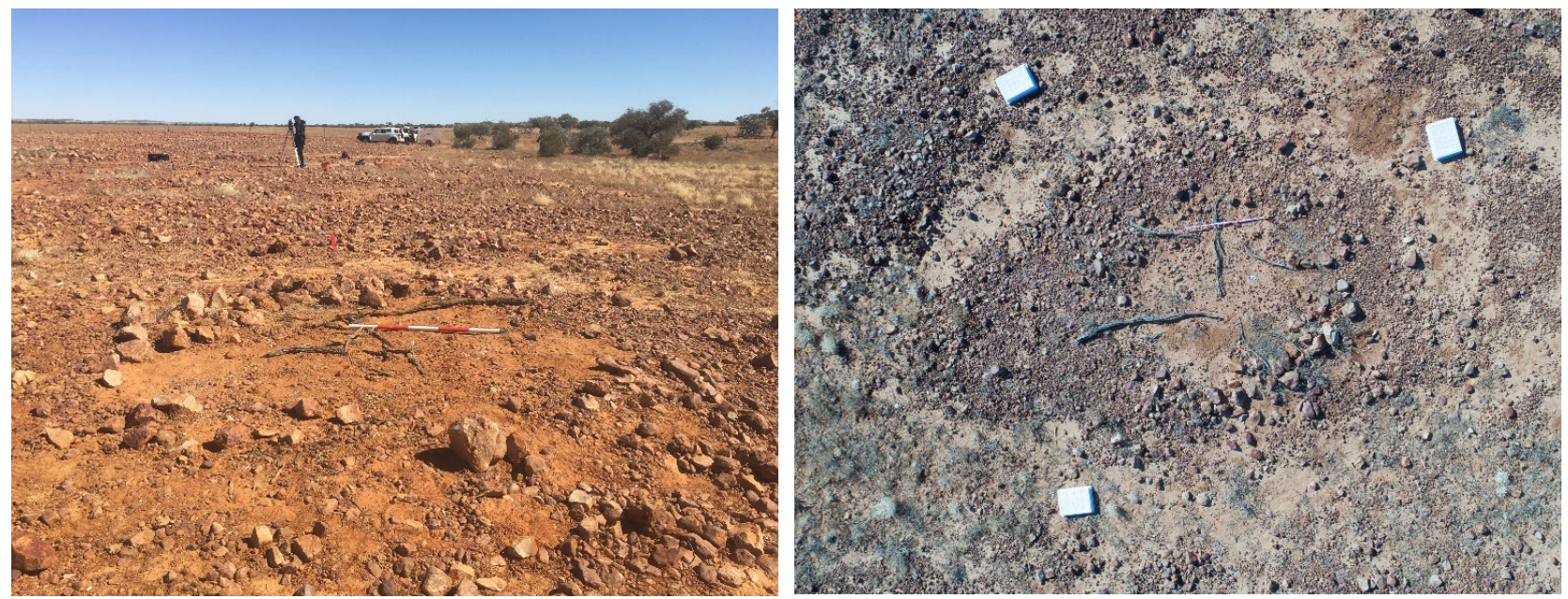

Figure 4. (left) High oblique view of Hut 1, looking west (ranging pole is oriented north-south with $20 \mathrm{~cm}$ increments) (Photograph: Lynley Wallis); (right) vertical view of Hut 1, with north to top of view (mini-rod is $1 \mathrm{~m}$ length) (Photograph: Andrew Schaefer). 

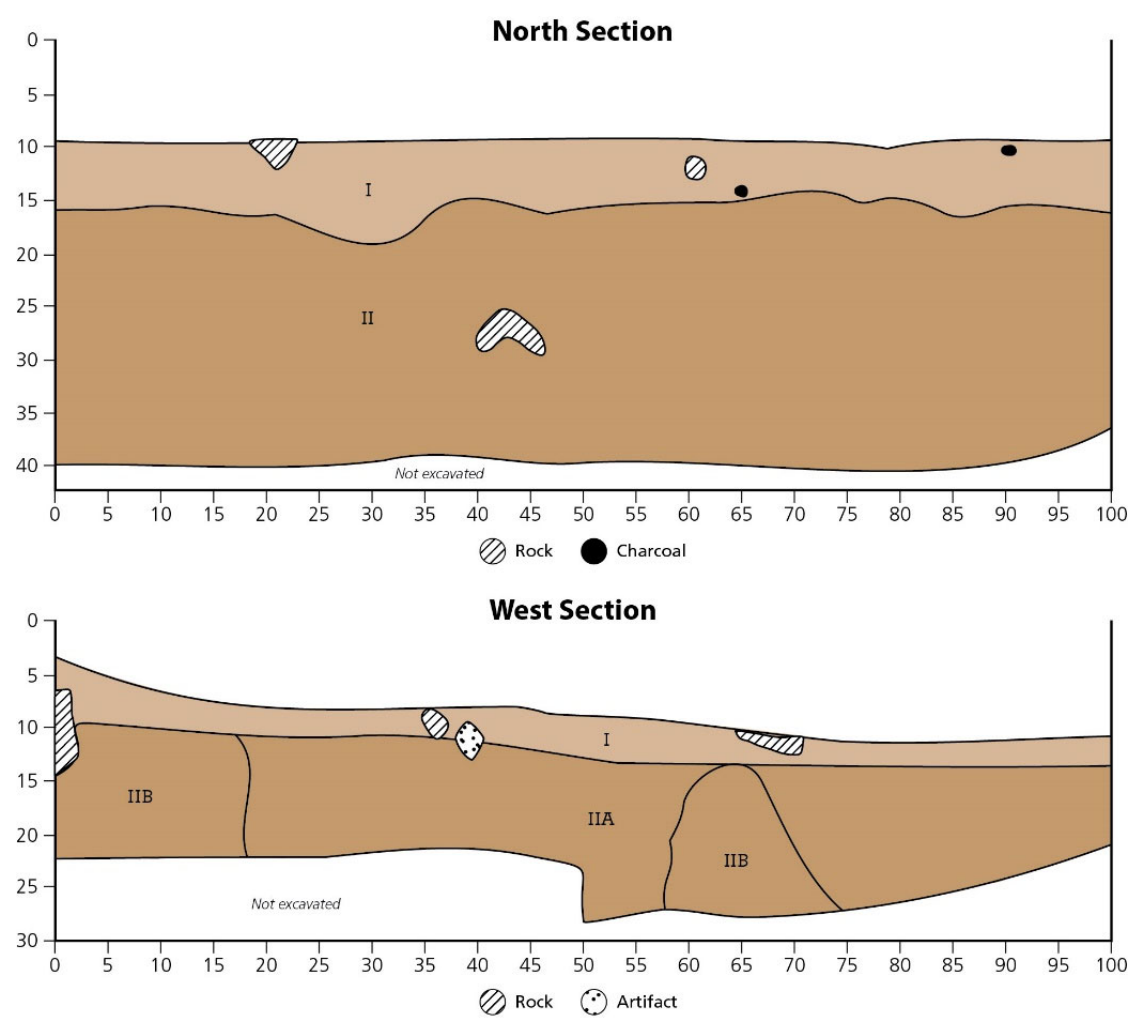

Figure 5. (top) North face stratigraphic section of Hut 1; (bottom) West face stratigraphic section of Hut 5, Hilary Creek Site 1.

Hut 5 was located towards the middle of the cluster of huts at HCS1 (Figure 6). Like Hut 1, it was also well preserved, with gidgee branches still present. A single 1 x $1 \mathrm{~m}$ test-pit, Square A, was excavated immediately outside Hut 5 in an area that contained mussel shell and flaked stone artefacts. Like Hut 1 Square A, Hut 5 Square A also consisted of two stratigraphic units (Figure 5, bottom). SU1 was a relatively loose sediment (5YR 5/8 yellowish red) interspersed with patches of blocky clay extending to a maximum depth of $9.1 \mathrm{~cm}$. SU2 was characterised by modular blocky clay sediments (5YR 5/8) that were more compacted and homogeneous than SU1, interspersed with friable orange material designated SU2b. SU2 extended to a depth of 26.3 $\mathrm{cm}$ and sat atop a hard compacted clay that was culturally sterile.

Four age estimates were obtained from Hut 5 Square A, two on in situ charcoal and two on shell taken from the sieves (Table 1, Figure 3). The dates on charcoal and shell from XU3 returned ages of 189 and 181 cal BP, respectively. Estimates on in situ charcoal and shell from XU4 returned dates of 167 and 185 cal BP, respectively. Although this excavation took place outside the entrance of the hut, it shows a similar pattern of mixing of cultural materials, again probably related to relatively shallow sediment within a concentrated activity area.

The suite of cultural materials from both excavations was broadly similar (Table 2). Stone artefacts dominated, with the main differences being the presence of several formal tools in Hut 5 (comprising three burren slugs and a tula slug in XU1) (Table 3). Most of the stone artefacts were on the surface and upper XUs in both huts, although the artefacts were more evenly distributed throughout the sedimentary sequence in the interior of Hut 1 . We suggest the disparity in discard rates between Hut 1 (20 artefacts) and Hut 5 (88 artefacts) reflects the existence of differential activity areas related to inside and outside activity. Amorphous flaked pieces dominated the lithic assemblages, constituting $65 \%$ and $56.8 \%$ of artefacts discarded, respectively. No cores were present and retouch was only present on six artefacts in Hut 5 in the uppermost three XUs. Broken flakes constituted $15 \%$ and $9 \%$ of the total assemblage in Hut 1 and Hut 5, respectively. Raw material was predominately silcrete, commensurate with that of the associated quarry, making up $75 \%$ and $43 \%$ of material type in Hut 1 and Hut 5, with quartz and chert similar in discard relative to each other in both sites (Appendix B). Chalcedony was only found in the uppermost XU of Hut 5.

The faunal assemblage consisted of small quantities of rodent and reptile bone, freshwater mussel (Velesunio ambiguus) and crustacean shell (possibly Cherax quadricarinatus) (Appendix C). The bone was highly fragmented, largely unburnt and only identifiable to order or genus. It was dominated by small rodent $(\mathrm{MNI}=9)$, with identification to genus Notomys (possibly the spinifex hopping-mouse, $N$. alexis) in XU4 of Hut 1. Rodent bone was found throughout the sequence in Hut 1, but only in the uppermost three XUs in Hut 5. Small lizard was recovered from XU2 of Hut 5, and part of a crustacean exoskeleton from XU6 in Hut 1. It is possible that the rodent and reptile bone is non-cultural, given the low MNI and the ubiquity of these animals in the natural landscape, and thus that the freshwater mussel and crustacean are the only unequivocally cultural fauna present. 

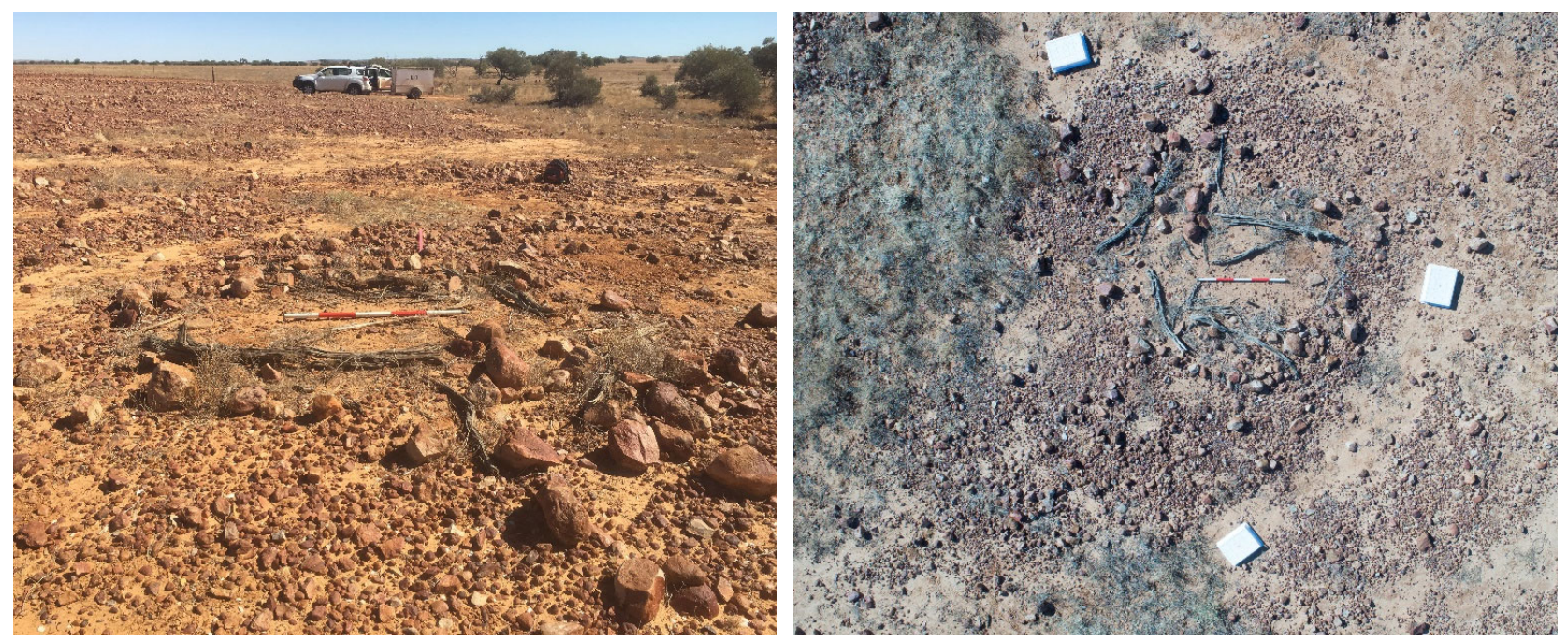

Figure 6. (left) High oblique view of Hut 5, looking west (ranging pole is oriented north-south with $20 \mathrm{~cm}$ increments) (Photograph: Lynley Wallis); (right) vertical view of Hut 5, with north to top of view (ranging pole is $1 \mathrm{~m}$ length) (Photograph: Andrew Schaefer).

Table 2. Cultural materials recovered from Hut 1 and Hut 5, HCS1; all values given as grams (g).

\begin{tabular}{|c|c|c|c|c|c|c|c|c|c|}
\hline Site & $\mathbf{X U}$ & Stone & Wood & $\begin{array}{l}\text { Mussel } \\
\text { Shell }\end{array}$ & Bone & Ochre & Landsnail & Crustacean & Charcoal \\
\hline \multirow{7}{*}{ Hut 1} & 1 & 32.0 & 9.80 & 9.47 & & & 1.51 & & \\
\hline & 2 & 0.59 & & 23.99 & 0.50 & 0.00 & 1.70 & & 0.21 \\
\hline & 3 & & & 14.40 & 0.49 & 0.00 & & & 0.25 \\
\hline & 4 & 5.93 & & 12.95 & 0.79 & 0.00 & & & 0.22 \\
\hline & 5 & 18.43 & & 15.31 & 1.00 & 0.07 & & & 2.25 \\
\hline & 6 & 0.29 & & 3.62 & 0.56 & & & 0.03 & \\
\hline & 7 & & & 2.92 & 0.21 & 0.00 & & & 0.30 \\
\hline \multirow{6}{*}{ Hut 5} & 1 & 229.32 & & 106.20 & 0.80 & & & & \\
\hline & 2 & 298.28 & & 51.06 & 0.83 & & & & 3.47 \\
\hline & 3 & 12.24 & & 16.94 & 0.52 & 1.30 & & & \\
\hline & 4 & & & 4.39 & & & & & \\
\hline & 5 & & & 1.69 & & & & & \\
\hline & 6 & & & 0.29 & & & & & 0.56 \\
\hline
\end{tabular}

Table 3. Lithic artefact types recovered from Hut 1 and Hut 5, HCS1.

\begin{tabular}{|c|c|c|c|c|c|c|c|c|}
\hline Site & $\mathbf{X U}$ & $\begin{array}{c}\text { Complete } \\
\text { Flake }\end{array}$ & $\begin{array}{l}\text { Retouched } \\
\text { Flake }\end{array}$ & $\begin{array}{l}\text { Distal } \\
\text { Flake }\end{array}$ & $\begin{array}{l}\text { Proximal } \\
\text { Flake }\end{array}$ & $\begin{array}{c}\text { Medial } \\
\text { Flake }\end{array}$ & $\begin{array}{c}\text { Flaked } \\
\text { Piece }\end{array}$ & Total \\
\hline \multirow{8}{*}{ Hut 1} & 1 & 2 & & 1 & 1 & & 3 & 7 \\
\hline & 2 & & & & & & 3 & 3 \\
\hline & 3 & & & & & & & \\
\hline & 4 & 1 & & 1 & & & 1 & 3 \\
\hline & 5 & 1 & & & & & 4 & 5 \\
\hline & 6 & & & & & & 2 & 2 \\
\hline & 7 & & & & & & & \\
\hline & Total & 4 & & 2 & 1 & & 13 & 20 \\
\hline \multirow{8}{*}{ Hut 5} & 1 & 22 & 4 & 1 & 3 & 1 & 43 & 74 \\
\hline & 2 & 1 & 1 & 2 & & & 4 & 8 \\
\hline & 3 & 1 & 1 & 1 & & & 3 & 6 \\
\hline & 4 & & & & & & & \\
\hline & 5 & & & & & & & \\
\hline & 6 & & & & & & & \\
\hline & 7 & & & & & & & \\
\hline & Total & 24 & 6 & 4 & 3 & 1 & 50 & 88 \\
\hline
\end{tabular}



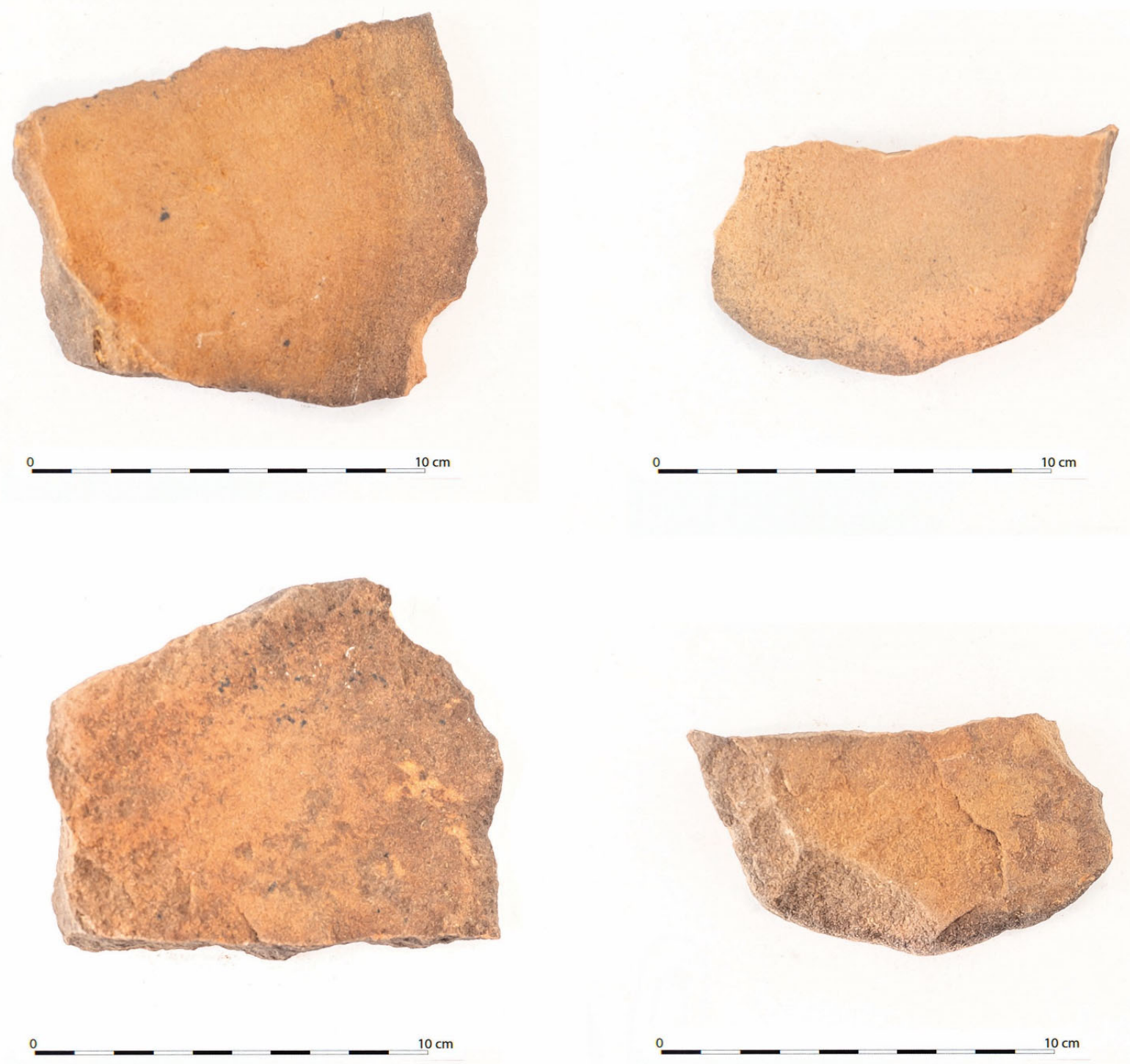

Figure 7. A sample of the grinding stones recovered from HCS1 (Photographs: David Matinelli).

\section{Other Surface Artefacts}

Beyond the stone huts (discussed above) and stone arrangements (discussed below), a large surface assemblage of cultural material was noted across the surface of HCS1. This was dominated by silcrete and chalcedony flaked artefacts (including numerous tula adzes). In addition, 34 fragmentary ground artefacts were identified and abundant, though highly fragmentary, freshwater mussel shell similar to that recovered from the excavations. The grinding stones were all sandstone, uniformly small and fragmentary, and therefore unlike the classic, usually large, grinding stone dishes of arid Australia (e.g. Smith 1989) (Figure 7, Appendix D).

\section{HSC1, HSC2 and HSC3 Stone Arrangements}

A total of 20 stone arrangements were recorded in the immediate proximity of HCS1 (Figure 8). With the exception of a single $\sim 100 \mathrm{~m}$ meandering line that stretched west from the margin of the huts to a silcrete outcrop, these stone features were diminutive, dominated by small filled circles $(n=11)$ and short linear features $(n=8)$ (Supplementary Online Material Table 5). HCS3 includes another seven arrangements that were similarly small, and that also included some small filled circles $(\mathrm{n}=3)$ (Figure 9). In contrast, at HCS2, $1.8 \mathrm{~km}$ downstream, 11 far more substantive stone arrangements were present, featuring long linear structures $(n=3)$ and large outlined circles $(n=3)$ (Figure 10). Unlike the stone arrangements at HCS1 and HCS3, which were more challenging to initially identify as they were positioned amidst the gibber, the stone arrangements of HCS2 were highly visible, being situated as they were on otherwise rock-free ground immediately adjacent to the creek. In all instances at all locations the stones used to construct the arrangements were locally available, typically $<50 \mathrm{~cm}$ in greatest dimension and were positioned atop the ground surface, rather than being dug in and embedded in place. 


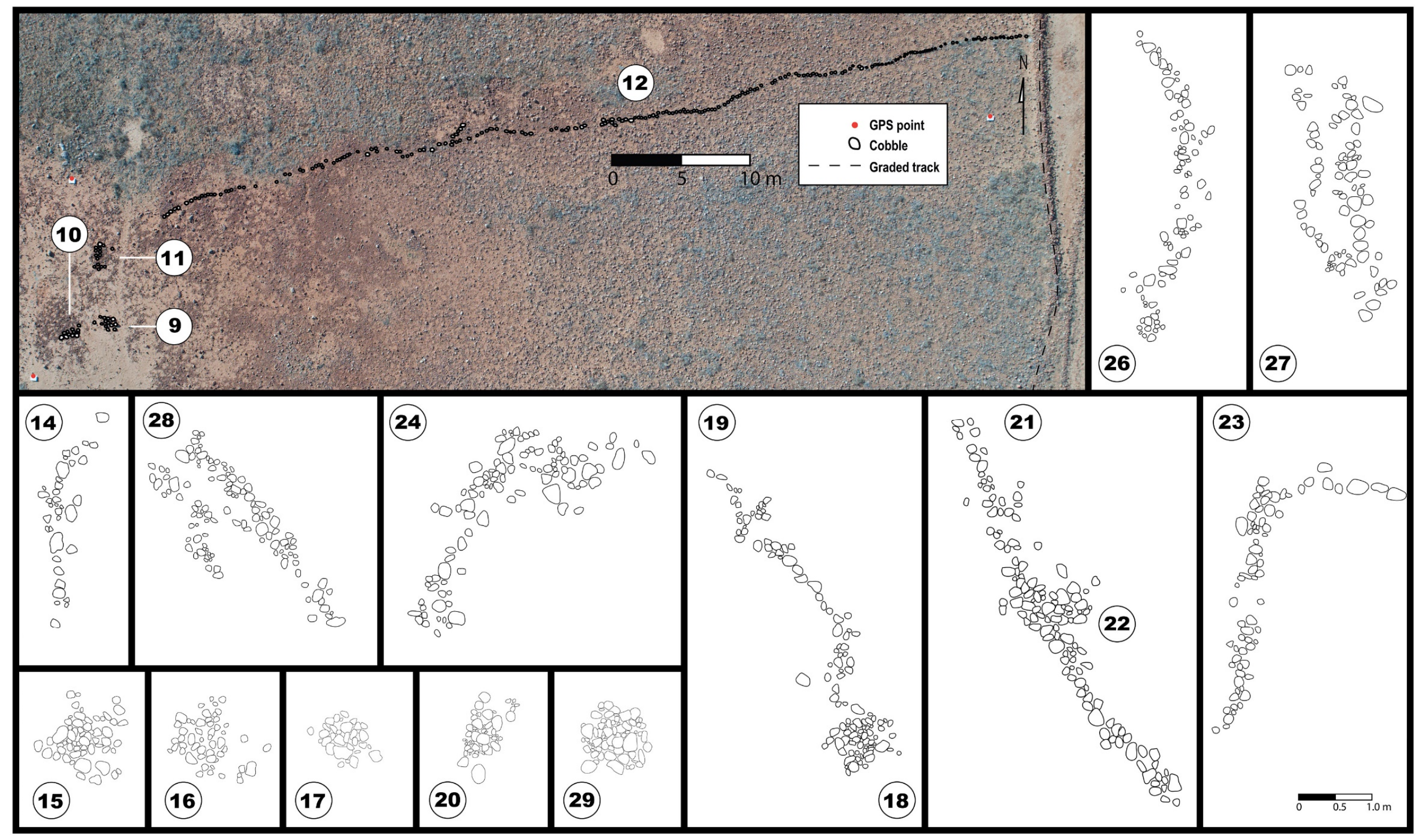

Figure 8. The stone arrangements at HCS1 (Photograph: Andrew Schaefer). 


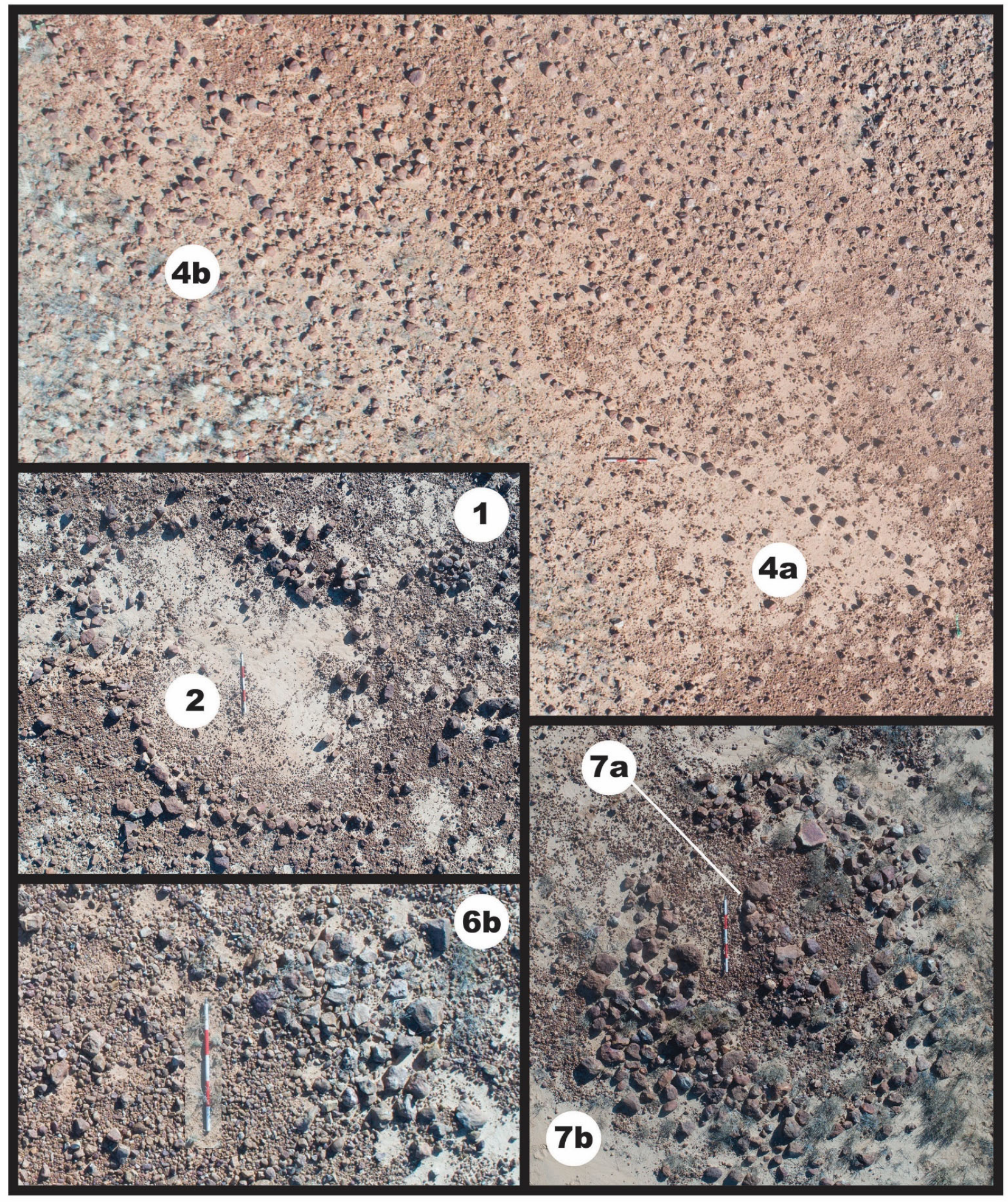

Figure 9. The stone arrangements at HCS3 (Photographs: Andrew Schaefer). 

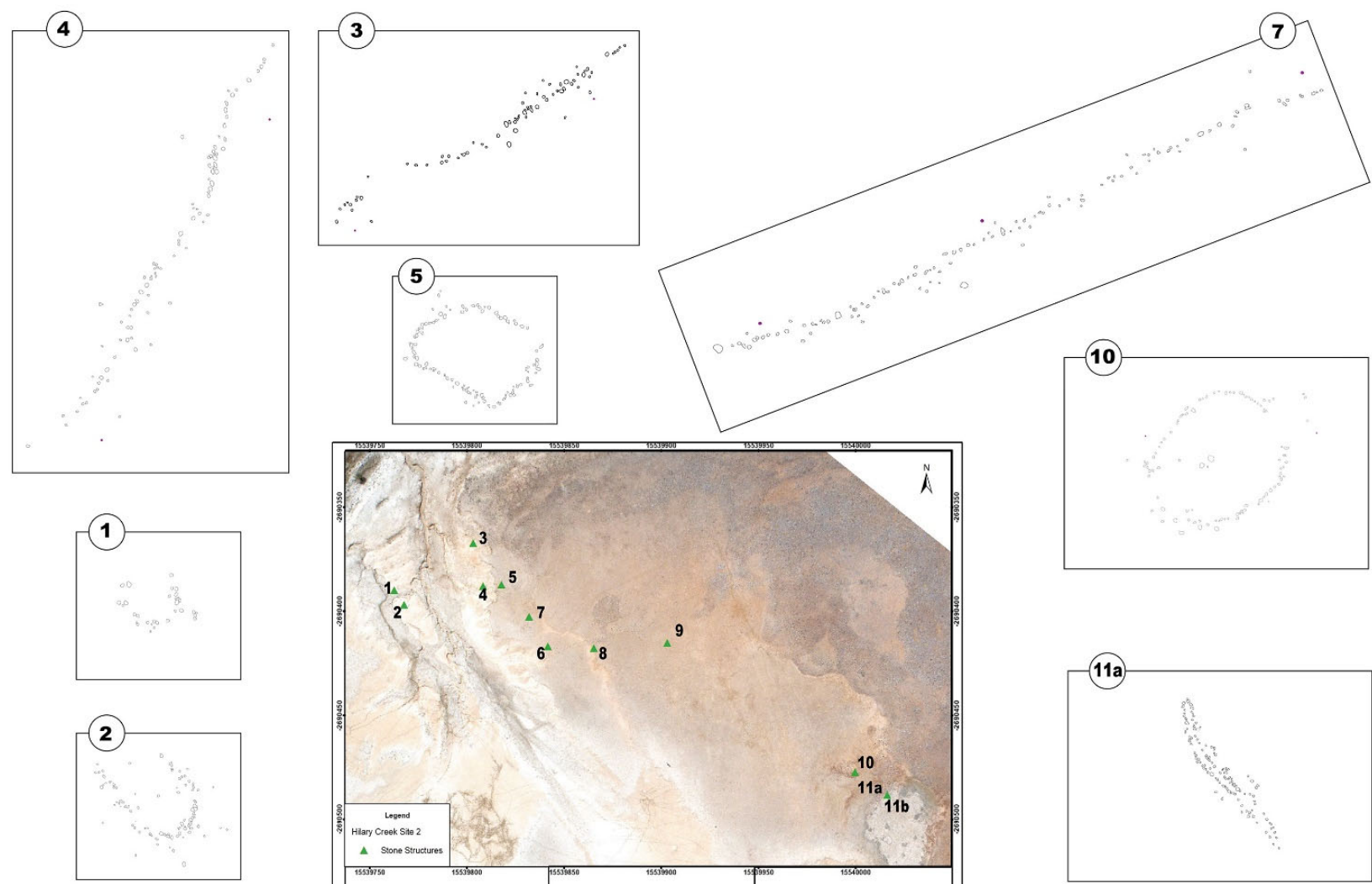

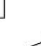
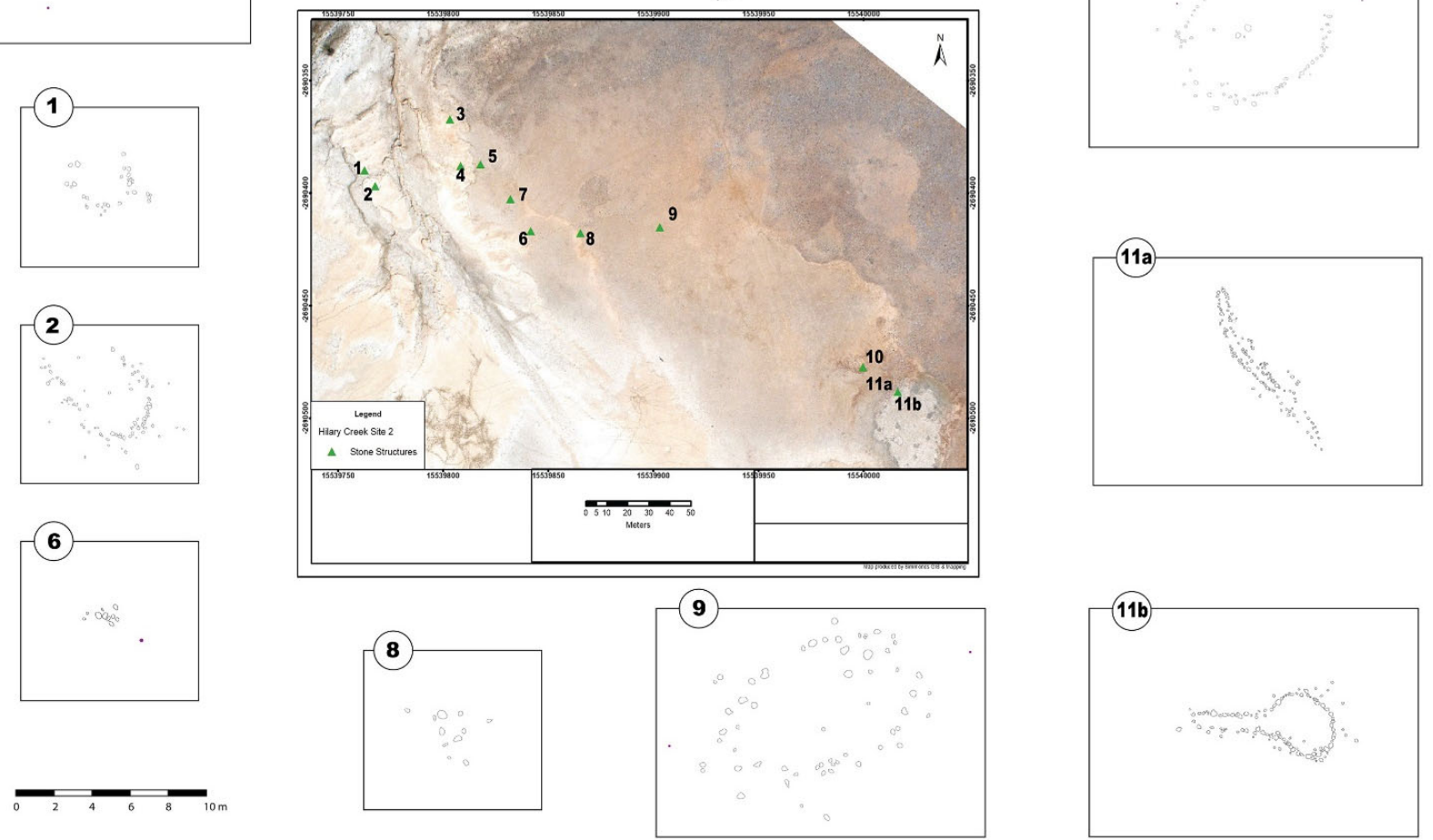

Figure 10. Detailed map showing the stone arrangements at HCS2.

\section{Discussion}

\section{Hut Construction and Use}

Despite the extensive disruptions that pastoralism brought to Aboriginal peoples' lives in western Queensland after the 1870 s, useful insights can be gleaned from the available written sources about hut structures that inform our understanding of the Hilary Creek huts.

On a map drawn during his 1876 expedition, Hodgkinson (1877:515) noted at least one 'native village' along both sides of Mytton's Lagoon about $100 \mathrm{~km}$ to the east of Hilary Creek, which he described in his diary as 'a large deserted native camp'. Although he provided no indication that it contained hut structures, his characterisation of the location as a 'village' of sufficient substance to be marked on a map implies that it was more, rather than less, substantial. Support for this proposition is found later in his diary, where he mentioned that: the rigors of the climate compel them [i.e. the local Aboriginal people] to build better places of shelter than in more northern latitudes. This they do by constructing a framework of timber, covered with grass, and then plastered with clay, forming, when complete, a circular hut about 9 feet in diameter, 5 feet high, and invariably with an opening to the N.W. (Hodgkinson 1877:519).

Ethnohistorical accounts of Aboriginal huts are also afforded by Lye (1877), Wells (1893:517) and Hill (1901:24); however, the greatest information about domestic architecture in Pitta Pitta country derives from Roth (1910). He described several types of built structures, the simplest being essentially a wind break, constructed of bundles of leafy switches fixed vertically into the soil (Roth 1910:57). A more substantial structure in the district was the 'kurau-I', designed to withstand rain with a similar but larger structure called the 'annakadyi', which was: 


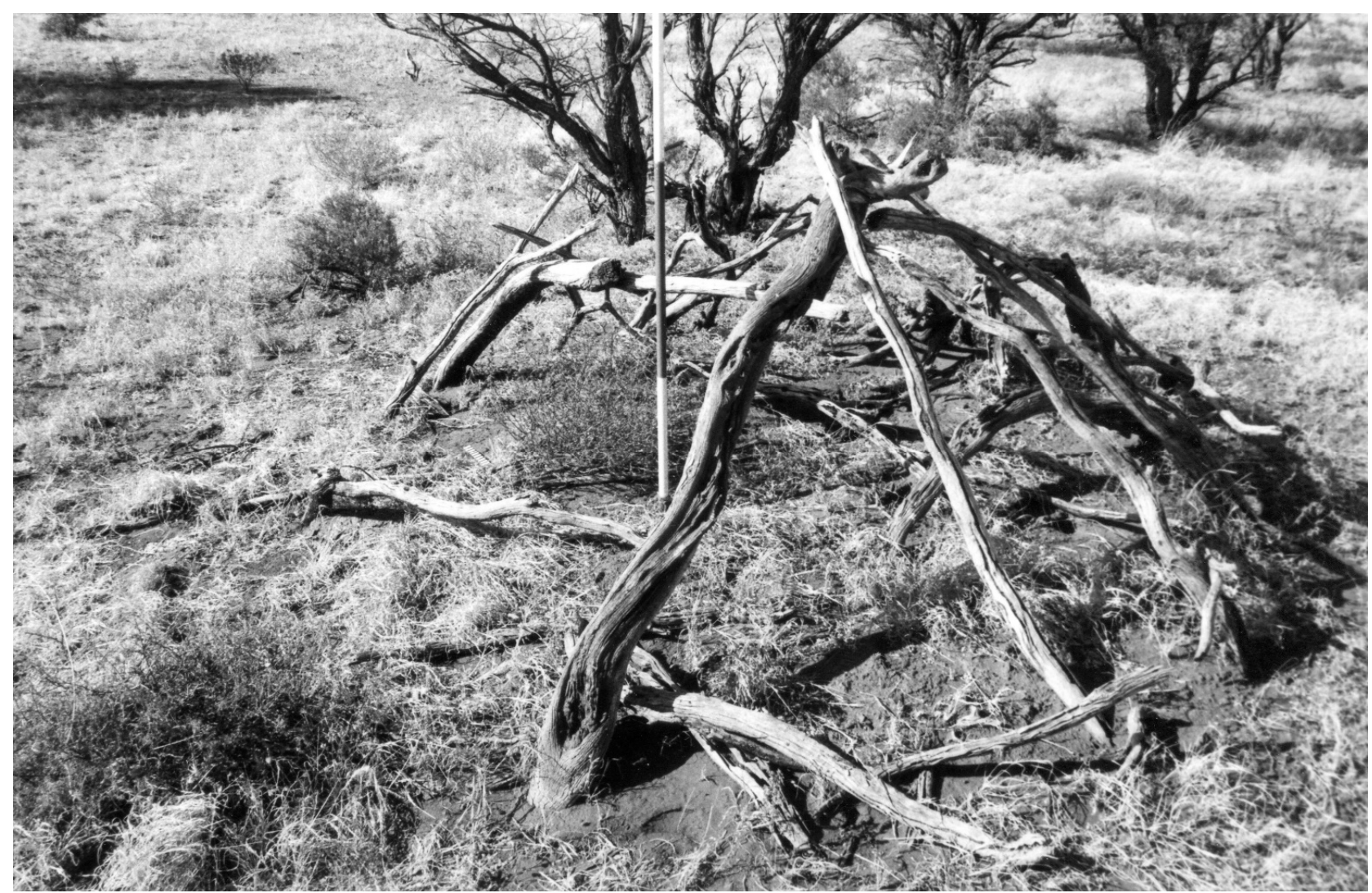

Figure 11. A gunyah of gidgee boughs on Glenormiston Station in 1982 (Photograph: Iain Davidson).

built on a similar scaffolding as the kuraui, but designed especially for warmth, and so for use in the winter months. A flat-bottomed hole is dug into the ground to a depth of about one and a half feet, or even more, the rather elliptical outline of its sides forming the limits of the habitation to be erected over it, the bottom of the excavation constituting the future floor. The frame-work of "back-bone" and "legs" is next inserted. Wet grass is then collected and wedged into the spaces intervening between the prinna, and thick layers of mud covered on; the mud thus moistened soon becomes hardened and, by means of the grass, fixed in position; a ring of wet mud about a foot in width is finally smeared round the limits of the entrance for which it forms a sort of artificial door-frame, and at the same time gives it a rather ornamental appearance. On completion, a big fire is kindled within, near the further side, opposite the door, with the result that, by sun-down, when the embers are removed, the place is warm enough to sleep in (Roth 1910:64).

Although none of the early descriptions mention foundations of stones, it is clear, based on such ethnohistorical accounts, that all the dwellings at Hilary Creek, both those with and without stone bases, would have had a dome-shaped superstructure supported by gidgee boughs covered by earth and/or vegetation, with a single opening to the northwest (Figure 11). These would have provided substantive protection from the bitter nights and chilling winds that dominate the region in winter. The presence of small quantities of charcoal recovered from the Hut 1 excavation at HCS1 suggests at least some of the Hilary Creek huts featured an interior fire in line with some ethnohistorical accounts.

When analysing the huts adjacent to the Marion Downs airstrip, Wallis et al. (2017:6) considered the possibility that such structures were only built after the arrival of Europeans. Certainly the Marion Downs airstrip huts contained an abundance of European material culture indicating use after the 1870s. Results from the investigation of the Hilary Creek huts, however, show they clearly pre-date European arrival in the region and thus represent a truly Indigenous building tradition; the absence of any European material across the complex (with the exception of a single, relatively recent tobacco tin discarded near a stone arrangement at HCS1) also supports the proposition that use of the Hilary Creek complex pre-dates the $1870 \mathrm{~s}$. Further, it stands to reason that at least some of the less well-preserved huts at the site must pre-date the last few hundred years, though there is no reason to suspect they are substantially older than the late Holocene period. Their varying preservation states clearly indicate that the huts were not used concurrently; we therefore think it unlikely this was a village in the sense that Pascoe (2014) or Westaway et al. (2019) might have suggested (see further below).

Despite their general similarity, even the well-preserved stone bases of the HCS1 huts contain noticeably fewer cobbles than those at the Marion Downs airstrip. For example, Hut 4, which is the best preserved of the HCS1 huts, has fewer than 100 cobbles in its base and there is no indication the base was more than a single course high. In contrast, most huts at the Marion Downs airstrip comprised several hundred cobbles, with surviving foundations of multiple courses up to $45 \mathrm{~cm}$ in height (Wallis et al. 2017). Further, comparing the internal size of the Hilary Creek huts with those from Marion Downs airstrip, demonstrates that the former are considerably smaller: just $3.2 \mathrm{~m}^{2}$ as opposed to $7.1 \mathrm{~m}^{2}$. This strongly 
suggests that the HCS1 huts were designed to accommodate fewer people; in the case of Hut 10 it appears only a single person could have occupied the interior. Taken as a whole, the cultural assemblage at HCS1 would indicate low intensity activity by very small numbers of people for relatively brief periods of time when water was available in the adjacent ephemeral creeklines. The shallow deposits, sparsity of faunal material unequivocally relating to subsistence and the very low densities of charcoal - both inside and outside the huts suggest that these were not used as 'ordinary' domestic shelters.

One alternative interpretation is that together the HCS1/HCS3 complex was a short-term trading camp (cf. Davidson et al. 2005; McBryde 1987; Mulvaney 1976), but this does not fit with the proximity of the stone arrangements. Further, the absence of any large grinding bases, despite the presence of numerous fragmentary ground pieces at the HCS1 is unusual. It is possible that large grinding bases were once present but have been removed by visitors. Such 'souvenirs' are commonly found at pastoral homesteads, having been collected by European landowners and labourers - but this is not the case at Marion Downs. Rather, we suggest that the unusual nature of the ground stone assemblage at HCS1 was related to the proximity of the huts to the stone arrangements, and use of the site as a ceremonial camp (see below) rather than a general domestic camp. Unlike the Marion Downs airstrip site (which was adjacent to a permanent waterhole), the HCS1 and HCS3 locales are not associated with a permanent stream or large waterhole. This suggests they were not year-round camping locations and could not support large groups of people. The small interiors of the huts, coupled with the knowledge that they were not all occupied at the same time, the presence of stone arrangements, and the unusual nature of the ground stone assemblage, collectively lead to our suggesting that this camp may have been a boys' initiation camp. This idea is explored further below, taking into consideration the relationship of the huts to the adjacent and nearby stone arrangements.

\section{Stone Arrangements}

One issue relating to the identification of stone arrangements generally is whether they are cultural or natural (Stead 1987) and, if cultural, whether they are 'authentically' Indigenous. In the Hilary Creek context, the repeated patterns, the size sorting of stones used, the unambiguous movement of stones into distinct alignments (especially at HCS2), supportive Aboriginal oral history (see below), and the lack of any natural or European cultural explanation for these patterns confirm their Aboriginal origins.

The question of the antiquity of the Hilary Creek stone arrangements cannot be answered definitively at this stage, though those at HCS1 might be reasonably assumed through association with the huts to be at least several hundred years old. In the Pilbara region it has been demonstrated that optically-stimulated luminescence (OSL) dating can be used to successfully ascertain the age of stone arrangements in open contexts, provided the stones have been firmly embedded in the ground surface (e.g. Hook and Di Lello 2010; Law et al. 2017:173). Nevertheless, stones in the Hilary Creek examples do not appear to have been deliberately embedded and are relatively small (compared to those in the Pilbara and in some other Queensland contexts), suggesting that OSL dating of sediments underlying them as a means of ascertaining their construction ages would need to be undertaken with extreme caution.

Somewhat surprisingly given Roth's presence, there is scant ethnographic and/or ethnohistoric information about stone arrangements in the study area. As noted earlier, the widespread violence associated with the NMP and pastoral period of the late nineteenth century rapidly impacted local Aboriginal traditional life, and our Pitta Pitta colleagues are unaware of any specific cultural knowledge about the Hilary Creek stone arrangements (though see below regarding Yulluna knowledge about the role of Ringu Ringu people). This did not, however, preclude them from considering the complex to be an important place of high cultural significance.

Even further afield it is apparent that detailed information on the function of stone arrangements is typically limited, no doubt in part owing to a reluctance on the part of Aboriginal people to share highly sensitive cultural knowledge with outsiders. In speaking of customs amongst the Myoli people around Brighton Downs, northeast of Marion Downs, Hill (1901:24) merely described the occurrence of initiation ceremonies associated with stone arrangements but offered no detail. In the area between Sylvester Creek and the Mulligan River (southwest of Marion Downs), Kelly (1968:565) simply reported the presence of circular stone arrangements containing piles of stones and connected by lines 'where the youth of the tribe were said to have been initiated' (see also McCarthy 1940:189). Senior Yulluna man Tom Sullivan (now deceased) advised Iain Davidson in the 1980s that the stone arrangements of his country (northwest of Marion Downs) were centres for ceremonial activities (Davidson et al. 1991:35, 46, 2005:129-130). Tom could recall bora ceremonies being conducted at such sites in the years immediately after World War II, with the last ceremonies involving the circumcision of initiates being performed in the late 1940s (Taylor 1995:30, 53, 54).

Perhaps most surprisingly, Roth (1897) never mentioned stone arrangements, an omission made all the more unusual given the considerable attention he paid to documenting songs, ceremonies, myths and rituals (e.g. Roth 1909). The fact that he never associated any of the latter with stone arrangements suggests two things. Firstly, Roth appears not to have travelled widely with the Aboriginal people from whom he collected knowledge, and particularly not south of Boulia where the bulk of huts and stone arrangements are known to occur (Davidson 2008:130). Secondly, Roth's lack of knowledge on this topic perhaps implies that Aboriginal people deliberately chose to withhold their knowledge from him. This would be in keeping with Aboriginal norms (Duncan-Kemp 1952; Sutton 2009). In this respect, Alfred Howitt's (1878:306) observations regarding stone arrangements of the Aboriginal people in the Cooper's Creek area southeast of Hilary Creek are telling: 'They ... were explained by the blacks to me as being play. I think they require more explanation'. It is entirely feasible therefore that, if the stone arrangements were associated with initiation ceremonies as we suggest, Roth's Pitta Pitta informants may have deliberately chosen not to share such knowledge with him.

Some support for this is also provided through regional oral histories recounted by Yulluna man Lance Sullivan (a nephew of the previously mentioned Tom Sullivan) to several of the authors in 2017 (Heather Burke, Lynley Wallis and 
Bryce Barker). Lance suggested the specific countrymen occupying the study area were known as Ringu Ringu (a dialect of Pitta Pitta; Blake 1979) and were important in the maintenance of several major songlines, as well as to ceremonial cycles related to young men's initiation. Such initiations required an isolated camp to which the boys/young men would travel in the company of older men, a journey that could take several months. Lance suggested that flooding and localised massacres shortly after the arrival of Europeans killed most of the Ringu Ringu speaking people who used the Hilary Creek site complex.

The separation of ceremonial grounds from associated camping areas is a key element in the spatial configuration of Aboriginal ceremonial locations (e.g. Satterthwait and Heather 1987). Often the local topography would be used to effect a visual barrier, such as at the Double Bore Crossing stone arrangement in Yulluna country, which was positioned so that it could not be seen from any surrounding camp sites (Beck 2016). The physical separation of the huts at HCS1 and HCS3 from the larger, more extensive and clearly visible stone arrangements at HCS2 would have served such a purpose if indeed the latter were ceremonial in nature. In contrast, the closer proximity of the smaller stone arrangements at HCS1 and HSC3 to the huts at these locales suggests that those particular stone arrangements were of a different, though perhaps related, purpose. Given the morphological differences between the two sets of stone arrangements this does not seem unreasonable. It would appear that the Hilary Creek complex fits a similar pattern to that found elsewhere in Australia, where a range of new ceremonial activities were established in the very late Holocene period (e.g. Barker et al. 2016; Greer et al. 2015; McIntyre-Tamwoy and Harrison 2004; McNiven 2016; Ross et al. 2013, Williams et al. 2015).

\section{Conclusions}

The Channel Country of western Queensland has long been known to have a rich, albeit largely surface, archaeological record. Although the paucity of rockshelter sites makes ascertaining when the region was first occupied difficult, the abundant surface sites are extremely well suited to a landscape approach focused on the spatial distribution of materials. Further, the ubiquitous presence of huts represents one of the few datable stratified site types in the Channel Country. The late establishment and apparently short duration of occupation at the Hilary Creek complex is interesting. The earliest occupation dates for the site date from 285 cal BP and seem to be abandoned by about 114 cal BP, a use-life of just 171 years. Although this may be a result of sampling and further dating is desirable, it seems unlikely that use of the huts extends beyond the late Holocene. The absence of permanent water, coupled with the small size of the huts and the paucity of excavated cultural material seem to indicate that they were not every day domestic shelters. Instead, we suggest that the most parsimonious explanation for their presence is their use during periods of ceremonial activity related to the nearby stone arrangements. We argue the abandonment of the Hilary Creek site complex, and in all likelihood the ceremonies associated with it, was a direct result of European incursion in the wider region, and eventually Hilary Creek itself, from the mid-to-late nineteenth century, which caused massive population decline, dispossession and disruptions to the social and economic systems of Aboriginal people.

\section{Acknowledgements}

In a project of this extent it is impossible to thank everyone individually, so we give our thanks to the many Aboriginal corporations, communities and individuals who have assisted us over the years, and to the colleagues, students and volunteers who have similarly offered their support. In particular we thank the Pitta Pitta Aboriginal Corporation for their support for our research, especially Lorna Bogdanek for her assistance in organising the permissions and fieldwork, and Frances Melville for her unwavering enthusiasm and ever-ready laugh. Lyndall Simmonds georectified the aerial imagery and prepared the site plans. We are grateful to the North Australian Pastoral Company (NAPCo) for permission to work on Marion Downs Station. Thanks also to the numerous reviewers of this paper, though the viewpoints presented remain those of the authors. This research was supported under the Australian Research Council's Discovery Projects funding scheme (project number DP160100307). Robert Jansen is the manager of Marion Downs Station on which this research was undertaken. Dennis Melville and Geoffrey Jacks are representatives of the Pitta Pitta Aboriginal Corporation and participated in the fieldwork. Anthony Pagels and Andrew Schaefer were graduate students at Flinders University at the time the fieldwork was undertaken and participated as volunteers in the fieldwork.

\section{References}

Alexander, R. 2005 A Field Guide to Plants of the Channel Country, Western Queensland. Currimundi: Channel Landcare Group.

Anon. 1861 The Burke and Wills Exploring Expedition: An Account of the Crossing of the Continent of Australia, from Cooper's Creek to Carpentaria. Melbourne: Wilson and Mackinnon. [Facsimile Edition 1963, Libraries Board of South Australia, Adelaide].

Artym, U.F. 2018 Profiling the Police: Exploring Officer-Trooper Interactions in the Queensland Native Mounted Police. Unpublished BArch (Hons) thesis, College of Humanities, Arts and Social Sciences, Flinders University, Adelaide.

Barker, B., L. Lamb and G. Campbell 2016 The Mine Island Aboriginal stone arrangements: Spiritual responses to late Holocene change on the central Queensland coast. Australian Archaeology 82(3):232-247. https://doi.org/10.1080/03122417.2016.1251725

Barton, H.J. 2001 Mobilising Lithic Studies: An Application of Evolutionary Ecology to Understanding Prehistoric Patterns of Human Behaviour in the Simpson Desert, Far Western Queensland. Unpublished PhD thesis, University of Sydney, Sydney.

Beck, W. 2016 More than Dots on Maps: GIS Viewshed Analysis and Australian Indigenous Archaeology. Unpublished BA (Hons) thesis, College of Arts, Society and Education, James Cook University, Townsville.

Blake, B. 1979 Pitta-Pitta. In R.M.W. Dixon and B. Blake (eds), Handbook of Australian Languages, pp.182-242. Canberra: ANU Press. https://doi.org/10.1075/z.hal1.07bla

Border, A. and M.J. Rowland 1990 The Mitchell Grass Downs Biogeographical Zone (Queensland): A Heritage Resource Assessment. Unpublished report to Heritage Branch, Department of Environment and Heritage (Brisbane) and the Australian Heritage Commission (Canberra).

Bronk Ramsey, C. 2017 Methods for summarizing radiocarbon datasets. Radiocarbon 59(2):1809-1833. https://doi.org/10.1017/ $\underline{\text { RDC. } 2017.108}$

Bureau of Meteorology (BoM) 2020 Climate Data Online (Marion Downs and Boulia Airport weather stations). Retrieved 3 August 2020 from $<$ http://www.bom.gov.au/climate/data/index.shtml $>$.

Burke, H. and L.A. Wallis 2019 Frontier Conflict and the Native Mounted Police in Queensland Database. https://doi.org/10.25957/ $\underline{5 \mathrm{~d} 9 \mathrm{fb} 541294 \mathrm{~d} 5}$

Queensland Archaeological Research | Vol. 24 | 2021 | 17 
Davidson, I. 1983 On the edge of the Simpson: Recent additions to understanding of prehistoric artefact distributions in arid Australia. Australian Archaeology 17:27-37. https://doi.org/10.1080/ $\underline{03122417.1983 .12092907}$

Davidson, I. 2008 Ethnological studies and archaeology of north west central Queensland. In R. McDougall and I. Davidson (eds), The Roth Family, Anthropology and Colonial Administration, pp.121-132. Walnut Creek: Left Coast Press.

Davidson, I., H. Burke and S. Mitchell 1989 Archaeological Sites in Northwest Central Queensland. Unpublished report to Australian Heritage Commission.

Davidson, I., H. Burke, L. A. Wallis, B. Barker, E. Hatte and N. Cole 2018 Connecting Myall Creek and the Wonomo. In J. Lydon and L. Ryan (eds), Remembering the Myall Creek Massacre, pp.100-111. Sydney: NewSouth Publishing.

Davidson, I., H. Burke, L. Sullivan, L.A. Wallis, U. Artym and B. Barker 2020 Cultural conflict in text and materiality: The impact of words and lead on the northwest Queensland colonial frontier. World Archaeology 51(5):724-740. https://doi.org/10.1080/00438243. 2020.1711153

Davidson, I., N. Cook, M. Fischer, M. Ridges, J. Ross and S. Sutton 2005 Archaeology in another country: Exchange and symbols in north-west central Queensland. In I. Macfarlane, M.J. Mountain and R. Paton (eds), Many Exchanges: Archaeology, History, Community and the Work of Isabel McBryde, pp.103-130. Aboriginal History Monograph 11. Canberra: Aboriginal History.

Davidson, I., I. Tarrago and T. Sullivan 2004 Market forces. In V. Donovan and C. Wall (eds), Making Connections: A Journey along Central Australian Aboriginal Trading Routes, pp.12-23. Brisbane: Arts Queensland.

Davidson, I., R. Cliff and T. Sullivan 1991 Burke River Pipeline. A Survey of the Impact on Archaeological Sites. Unpublished report to Cyprus Gold Australia Corporation.

Duncan-Kemp, A.M. 1952 Queensland Aboriginal lore. Mankind 4(9):382-388.

Fitzpatrick, A., I.J. McNiven, J. Specht and S. Ulm 2018 Stylistic analysis of stone arrangements supports regional cultural interactions along the northern Great Barrier Reef, Queensland. Australian Archaeology 84(2):129-144. https://doi.org/10.1080/ 03122417.2018.1507807

Friedman, G.M. 1959 Identification of carbonate minerals by staining methods. Journal of Sedimentary Research 29(1):87-97. https://doi.org/10.1306/74D70894-2B21-11D7$\underline{8648000102 \mathrm{C} 1865 \mathrm{D}}$

Greer, S., R. Henry and S. McIntyre-Tamwoy 2015 Mainland magic: Interpreting cultural influences across Cape York-Torres Strait. Quaternary International 385:69-78. https://doi.org/10.1016/ j.quaint.2014.12.021

Hill, S. 1901 Ceremonies, customs and foods of the Myorli tribe. Science of Man 2(4):24-25.

Hiscock, P. 1988 A cache of tulas from the Boulia district, western Queensland. Archaeology in Oceania 23(2):60-70. https://doi.org/ 10.1002/j.1834-4453.1988.tb00188.x

Hodgkinson, W.O. 1877 North-West Exploration Diary 13 April-27 September 1876. Queensland Legislative Council Journal 25:507530.

Hook, F. and A. Di Lello 2010 Gurdadaguji stone arrangements: Late Holocene aggregation locals. In D. Caldado, M. Baldia and M. Boulanger (eds), Monumental Questions: Prehistoric Megaliths, Mounds and Enclosures, pp.285-297. BAR International Series 2123. Oxford: Archaeopress.
Howitt, A.W. 1878 Appendix D: Notes on the Aborigines of Coopers Creek. In R. Brough Smyth (ed.), The Aborigines of Victoria, pp.300-309. London: Government Printer.

Kelly, J.D. 1968 Hut sites, rock engravings, stone arrangements, and Tjurunga, Mulligan River, Queensland. Mankind 6(11):563-565. https://doi.org/10.1111/j.1835-9310.1968.tb00333.x

Kreij, A., J. Scriffignano, D. Rosendahl, T. Nagel and S. Ulm 2018 Aboriginal stone-walled intertidal fishtrap morphology, function and chronology investigated with high-resolution close-range Unmanned Aerial Vehicle photogrammetry. Journal of Archaeological Science 96:148-161. https://doi.org/10.1016/j.jas.2018.05.012

Law, W.B., M.J. Slack, B. Ostendorf and M.M. Lewis 2017 Digital terrain analysis reveals new insights into the topographic context of Australian Aboriginal stone arrangements. Archaeological Prospection 24(2):169-179. https://doi.org/10.1002/arp.1567

Lye, J. 1877 Untitled. Brisbane Courier 30 July 1877, p.2.

Mackie, C.W. 1901 Mi-orli and Kal-ra-doon tribes. Science of Man and Journal of the Royal Anthropological Society 4(8):133.

McBryde, I. 1987 Goods from another country: Exchange networks and the people of the Lake Eyre basin. In D.J. Mulvaney and J.P. White (eds), Australians: A Historical Library Australians to 1788, pp.253-273. Broadway: Fairfax, Syme and Weldon Associates.

McCarthy, F.D. 1940 Aboriginal stone arrangements in Australia. The Australian Museum Magazine 2:184-189.

McConnel, U. 1932 Totem stones of the Kantyu tribe, Cape York Peninsula, north Queensland. Oceania 2(3)3:292-295. https://doi.org/10.1002/j.1834-4461.1932.tb00030.x

McDonald, J. and M. Berry 2017 Murujuga, northwestern Australia: When arid hunter-gatherers became coastal foragers. The Journal of Island and Coastal Archaeology 12(1):24-43. https://doi.org/ $\underline{10.1080 / 15564894.2015 .1125971}$

McIntyre-Tamwoy, S. and R. Harrison 2004 Monuments to colonialism? Stone arrangements, tourist cairns and turtle magic at Evans Bay, Cape York. Australian Archaeology 59:31-42. https://doi.org/10.1080/03122417.2004.11681789

McKinlay, J. 1861-1862 Journal of Explorations in the Interior of Australia (Burke Relief Expedition). Melbourne: Bailliere [Facsimile Edition, 1962].

McNiven, I.J. 2016 Increase rituals and environmental variability on small residential islands of Torres Strait. The Journal of Island and Coastal Archaeology 11(2):195-210. https://doi.org/10.1080/ $\underline{15564894.2015 .1115789}$

McNiven, I.J., J.E. Dunn, J. Crouch and Gunditj Mirring Traditional Owners Aboriginal Corporation 2017 Kurtonitj stone house: Excavation of a mid-nineteenth century Aboriginal frontier site from Gunditjmara country, south-west Victoria. Archaeology in Oceania 52(3):171-197. https://doi.org/10.1002/arco.5136

Memmott, P. 2007 Gunyah, Goondie and Wurley: The Aboriginal Architecture of Australia. St Lucia, QLD: University of Queensland Press.

Mulvaney, D.J. 1976 The chain of evidence. In N. Peterson (ed.), Tribes and Boundaries in Australia, pp.72-94. Social Anthropology Series 10. Canberra: Australian Institute of Aboriginal Studies.

Pascoe, B. 2014 Dark Emu Black Seeds: Agriculture or Accident? Broome: Magabala Books.

Paten, R.J. 1964 The Tertiary Geology of the Boulia Region, Western Queensland. Bureau of Mineral Resources, Geology and Geophysics Report 77. Canberra: Department of National Development.

Pearson, M. and J. Lennon 2010 Pastoral Australia: Fortunes, Failures and Hard Yakka: A Historical Overview 1788-1967. Clayton: CSIRO Publishing. https://doi.org/10.1071/ $\underline{9780643100503}$ 
Phelps, D.G., K.A. Day, M.R. Jeffery, P.T. Connelly, G.W. Fraser, B.S. McCallumn, M.T. Sullivan, I.A. White, S.A. Robertson and D.H. Cobon 2003 Sustainable Grazing in the Channel Country Floodplains. A Technical Report on Findings between June 1999 and August 2002. North Sydney: Meat and Livestock Australia.

Piotto, E.L., A. Ross, C. Perryman and S. Ulm 2018 Deliberate selection of rocks in the construction of the Gummingurru stone arrangement site complex, Darling Downs, Queensland. Queensland Archaeological Research 21:27-38. https://doi.org/10.25120/ qar.21.2018.3649

Popic, T.J. and G.M. Wardle 2012 Extremes: Understanding flowervisitor interactions in a changing climate. In D. Lunney and P. Hutchings (eds), Wildlife and Climate Change: Towards Robust Conservation Strategies for Australian Fauna, pp.99-106. Mosman: Royal Zoological Society of New South Wales. https://doi.org/10.7882/FS.2012.016

Reimer, P.J., E. Bard, A. Bayliss, J.W. Beck, P.G. Blackwell, C.B. Ramsey, C.E. Buck, H. Cheng, R.L. Edwards, M. Friedrich, P.M. Grootes, T.P. Guilderson, H. Haflidason, I. Hajdas, C. Hatté, T.J. Heaton, D.L. Hoffmann, A.G. Hogg, K.A. Hughen, K.F. Kaiser, B. Kromer, S.W. Manning, M. Niu, R.W. Reimer, D.A. Richards, E.M. Scott, J.R. Southon, R.A. Staff, C.S.M. Turney and J. van der Plicht2013 IntCal13 and Marine13 radiocarbon age calibration curves 0-50,000 years cal BP. Radiocarbon 55(4):1869-1887. https://doi.org/10.2458/azu_js_rc.55.16947

Reynolds, M.A. 1964 Explanatory Notes on the Bedourie Geological Sheet: Records 1964/123. Canberra: Bureau of Mineral Resources Geology and Geophysics, Department of National Development.

Reynolds, M.A., F. Olgers and W. Jauncey 1961 Geology of the Bedourie, Machattie, Birdsville, Betoota 4-Mile Sheet Areas in Western Queensland. Canberra: Bureau of Mineral Resources Geology and Geophysics, Department of National Development.

Richards, J. 2008 The Secret War: A True History of Queensland's Native Police. St Lucia, QLD: University of Queensland Press.

Ritchie, M. 1996 Marion Downs Cultural Heritage Sites. Unpublished report to North Australian Pastoral Company.

Robins, R. 1981 Four Aboriginal dwelling sites in southwest Queensland. Australian Archaeology 12:79-90. https://doi.org/ $\underline{10.1080 / 03122417.1981 .12092802}$

Ross, A. 2008 Managing meaning at an ancient site in the 21st century: The Gummingurru Aboriginal stone arrangement on the Darling Downs, southern Queensland. Oceania 78(1):91-108. https://doi.org/10.1002/j.1834-4461.2008.tb00030.x

Ross, A., S. Ulm and B. Tobane 2013 Gummingurru-A community archaeology knowledge journey. Australian Archaeology 76:62-68. https://doi.org/10.1080/03122417.2013.11681966

Roth, W.E. 1897 Ethnological Studies Among the North-WestCentral Queensland Aborigines. Brisbane: Government Printer.

Roth, W.E. 1909 North Queensland Ethnography Bulletin 12: On certain initiation ceremonies. Records of the Australian Museum 7(3):166-185. https://doi.org/10.3853/j.0067-1975.7.1909.960

Roth, W.E. 1910 North Queensland Ethnography Bulletin 16: Huts and shelters. Records of the Australian Museum 8(1):55-66. https://doi.org/10.3853/j.0067-1975.8.1910.934

Rowlands, R.J. and J.M. Rowlands 1966a Aboriginal stone arrangements in the Western Desert of Australia. The Australian Journal of Anthropology 6(8):355-358. https://doi.org/10.1111/ j.1835-9310.1966.tb00373.x

Rowlands, R.J. and J.M. Rowlands 1966b Visit to Western New South Wales and South Western Queensland, June 1966. Unpublished report to Australian Institute of Aboriginal Studies.
Rowlands, R.J. and J.M. Rowlands 1967 Report of a Visit to NorthWestern New South Wales and South-Western Queensland, MayJune 1967. Unpublished report to Australian Institute of Aboriginal Studies.

Rowlands, R.J. and J.M. Rowlands 1970 Aboriginal Stone Arrangements. Report on Field Work in North Western New South Wales and South Western Queensland, June-July 1970. Unpublished report to Australian Institute of Aboriginal Studies.

Rowlands, R.J. and J.M. Rowlands 1972 Aboriginal Stone Arrangements. Report on Field Work in South Western Queensland, June-August 1972. Unpublished report to Australian Institute of Aboriginal Studies.

Rowlands, R.J. and J.M. Rowlands 1973 Aboriginal Stone Arrangements. Report on Field Work in North Western New South Wales and South Western Queensland, July-August 1973. Unpublished report to Australian Institute of Aboriginal Studies.

Rowlands, R.J. and J.M. Rowlands 1976 Aboriginal Stone Arrangements. Report on Field Work in Western New South Wales and Queensland, Jun-Aug. 1976. Unpublished report to Department of Aboriginal and Islander Advancement.

Rowlands, R.J. and J.M. Rowlands 1978 Aboriginal Stone Arrangements. Report on Field Work in Western New South Wales and Queensland: August-October 1978. Unpublished report to Department of Aboriginal and Islander Advancement.

Rowlands, R.J. and J.M. Rowlands 1980 Aboriginal Stone Arrangements. Reports on Fieldwork in Western Queensland and North Eastern South Australia September - November 1980. Unpublished report to Department of Aboriginal and Islander Advancement.

Rowlands, R.J. and J.M. Rowlands 1982 Aboriginal Stone Arrangements. Reports on Fieldwork in Western New South Wales, Western Queensland, and North Eastern South Australia September - November 1982. Unpublished report to Department of Aboriginal and Islander Advancement.

Rowlands, R.J. and J.M. Rowlands 1985 Aboriginal Stone Arrangements : Report on Field Work in Western New South Wales, Western Queensland and North Eastern South Australia, August November, 1985. Unpublished report to Department of Aboriginal and Islander Advancement.

Satterthwait, L. and A. Heather 1987 Determinants of earth circle site location in the Moreton region, southeast Queensland. Queensland Archaeological Research 4:5-53. https://doi.org/ $\underline{10.25120 / q a r .4 .1987 .171}$

Smith, M.A. 1989 Seed gathering in inland Australia: Current evidence from seed-grinders on the antiquity of the ethnohistorical pattern of exploitation. In D.R. Harris and G. Hillman (eds), Foraging and Farming: The Evolution of Plant Exploitation, pp.305-317. London: Unwin Hyman.

Spencer, W.B. and F.J. Gillen 1901 Arrernte welcoming dance, entrance of the strangers, Alice Springs, Central Australia, 9 May 1901. Retrieved 30 August 2020 from $<$ https://commons.wikimedia.org/wiki/File:Arrernte welcoming da nce,_entrance_of_the_strangers,_Alice_Springs,_Central_Australia ,_9_May_1901__(cropped).jpg >.

Stead, R. 1987 Towards a Classification of Australian Aboriginal Stone Arrangements: An Investigation of Methodological Problems with a Gazetteer of Selected Sites. Unpublished MA thesis, Department of Prehistory and Anthropology, Australian National University, Canberra.

Strahan, R. (ed.) 1983 The Australian Museum Complete Book of Australian Mammals: The National Photographic Index of Australian Wildlife. London: Angus and Robertson. 
Sutton, P. 2009 The Politics of Suffering: Indigenous Australia and the End of the Liberal Consensus. Melbourne: Melbourne University Press.

Taylor, J.C. 1995 Anthropological Survey of the Placer Pacific Osborne Project. Unpublished report to Placer Pacific.

Towle, C.C. 1936 A bibliography of stone arrangements found in Australia. The Australian Journal of Anthropology 2(7):216-221. https://doi.org/10.1111/j.1835-9310.1939.tb00966.x

Walker, F. 1862 Diary of Expedition. Original manuscript held in National Library of Australia, Canberra.

Wallis, L.A., I. Davidson, H. Burke, S. Mitchell, B. Barker, E. Hatte, N. Cole and K. Lowe 2017 Aboriginal stone huts from the Georgina River, southwest Queensland. Queensland Archaeological Research 20:1-8. https://doi.org/10.25120/qar.20.2017.3584

Wallis, L.A. and J. Matthews 2016 Built structures in rockshelters of the Pilbara, Western Australia. Records of the Western Australian Museum 31(1):1-26. https://doi.org/10.18195/issn.0312-3162.31(1). $\underline{\text { 2016.001-026 }}$

Wells, F.H. 1893 Habits, customs and ceremonies of the Aboriginals of the Diamantina, Herbert and Eleanor Rivers in east Central Australia. Report of the Australasian Association for the Advancement of Science 5:515-522.

Westaway, M., J. Gorringe, D. Williams, K. Lowe and N. Wright 2019 Investigating the Record for Food Production and Villages in Channel Country, Western Queensland. Unpublished paper to Australian Archaeological Association Annual Conference, Gold Coast, 10-13 December.

Whitehouse, F.W. 1948 The geology of the Channel country of southwestern Queensland. In Anon. (ed.), The Channel Country of Southwest Queensland with Special Reference to Cooper's Creek, pp.10-28. Queensland Bureau of Investigation Technical Bulletin 1. Brisbane: Bureau of Investigation, Department of Public Lands.
Williams, A.N., S. Ulm, C.S.M. Turney, D. Rhode and G. White 2015 Holocene demographic changes and the emergence of complex societies in prehistoric Australia. PLoS One 10(6):e0128661. https://doi.org/10.1371/journal.pone.0128661

Wills, W.J. 1861 Field Book No. 5. Retrieved 25 June 2020 from $<$ www.burkeandwills.net.au/Journals/Wills_Journals/Wills_Field_ Book_05.htm>.

Wilson, P.R. 1990 Topography, geomorphology, geology and hydrology: Part VI. In P.R. Wilson, R.W. Purdie and C.R. Ahern (eds), Western Arid Region Land Use Study, pp.3-8. Technical Bulletin 28. Brisbane: Division of Land Utilisation, Department of Primary Industries.

Wood Jones, F. 1925 The ordered arrangement of stones present in certain parts of Australia. The Journal of the Royal Anthropological Institute of Great Britain and Ireland 55:123-128. https://doi.org/10.2307/2843696

Citation: Wallis, L.A., B. Barker, H. Burke, M. Dardengo, R. Jansen, D. Melville, G. Jacks, A. Pagels, A. Schaefer and I. Davidson 2021 Huts and stone arrangements at Hilary Creek, western Queensland: Recent fieldwork at an Australian Aboriginal site complex. Queensland Archaeological Research 24:1-47. https://doi.org/10.25120/qar.24.2021.3799 
Appendix A. Summary information about huts recorded at HCS1.

\begin{tabular}{|c|c|c|c|c|c|c|c|c|c|}
\hline $\begin{array}{l}\text { Hut } \\
\text { No. }\end{array}$ & $\begin{array}{l}\text { Width of } \\
\text { External } \\
\text { Base (m) }\end{array}$ & $\begin{array}{c}\text { Interior } \\
\text { Diameter } \\
\text { (m) }\end{array}$ & $\begin{array}{c}\text { Interior } \\
\text { Area }\left(\mathbf{m}^{2}\right) \\
\text { (based on } \\
\text { diameter) }\end{array}$ & $\begin{array}{c}\text { Opening } \\
\text { Orientation }\end{array}$ & $\begin{array}{c}\text { Associated } \\
\text { Cultural Material }\end{array}$ & $\begin{array}{c}\text { Surface } \\
\text { Wood } \\
\text { (present } \\
\text { /absent) }\end{array}$ & Description & Type & Radiocarbon Age/s (BP) \\
\hline $\begin{array}{c}\text { Hut } \\
1\end{array}$ & 5 & 2.5 & 4.91 & $\begin{array}{l}350^{\circ} \\
\text { (north) }\end{array}$ & $\begin{array}{l}\text { Surface mussel shell } \\
\text { fragments; stone } \\
\text { artefacts (including } \\
\text { a chalcedony flake } \\
\text { to the south of the } \\
\text { southern edge of the } \\
\text { mound) }\end{array}$ & present & $\begin{array}{l}\text { Situated on a slightly raised mound ( } \sim 30 \mathrm{~cm} \text { in height). } \\
\text { The western margin of the hut is the best preserved with } \\
\text { the larger stones still in situ. The external boundary of the } \\
\text { mound that makes up the external base of the hut is } \\
\text { covered in small gibber pebbles to the north and east, } \\
\text { extending } \sim 2 \mathrm{~m} \text { to the north. The interior of the hut has a } \\
\text { build-up of soft sediment with a small isolated gidgee } \\
\text { branch and gidgee fragments present on the surface } \\
\text { (possibly part of the original superstructure). }\end{array}$ & 1 & $\begin{array}{l}145 \pm 25 \text { (surface wood) } \\
175 \pm 20 \text { (SqA XU4 shell) } \\
23 \pm 16 \text { (SqA XU4 charcoal) } \\
227 \pm 20 \text { (SqA XU6 shell) } \\
161 \pm 16 \text { (SqA XU6 charcoal) }\end{array}$ \\
\hline $\begin{array}{c}\text { Hut } \\
2\end{array}$ & 4.8 & 2.3 & 4.15 & $\begin{array}{l}350^{\circ} \\
\text { (north) }\end{array}$ & $\begin{array}{l}\text { Large fragments of } \\
\text { mussel shell evident } \\
\text { on the surface, } \\
\text { along with silcrete } \\
\text { flakes and cores, } \\
\text { some of which } \\
\text { appear to have been } \\
\text { structure }\end{array}$ & absent & $\begin{array}{l}\text { Hut } 2 \text { has a large base on slightly raised mound }(\sim 15 \mathrm{~cm} \text { in } \\
\text { height). The eastern margin of the hut is the best preserved } \\
\text { location with the larger stones still in situ. Some soft } \\
\text { sediment is present in interior, but much less than Hut } 1 \text {, } \\
\text { and the interior is not clear as stones have been dispersed } \\
\text { across the centre of the hut. }\end{array}$ & 2 & nil \\
\hline $\begin{array}{c}\text { Hut } \\
3\end{array}$ & 3.9 & 2.5 & 4.91 & $\begin{array}{c}0^{\circ} \\
\text { (north) }\end{array}$ & $\begin{array}{l}\text { Large fragments of } \\
\text { mussel shell; } \\
\text { chalcedony and } \\
\text { silcrete stone } \\
\text { artefacts }\end{array}$ & present & $\begin{array}{l}\text { Large hut, highly broken up with considerable movement } \\
\text { of stones. Some very large stones appear to have been } \\
\text { placed in a line across the interior of this hut. There is a } \\
\text { gidgee bough on top of this 'line' and other small gidgee } \\
\text { boughs scattered across the surface of the hut. Some build- } \\
\text { up of sediment in the centre of the mound which is } \sim 10 \mathrm{~cm} \\
\text { at its highest point (centre of mound). }\end{array}$ & 1 & $113 \pm 28$ (surface wood) \\
\hline
\end{tabular}


Appendix A. Summary information about huts recorded at HCS1 (cont.).

\begin{tabular}{|c|c|c|c|c|c|c|c|c|c|}
\hline $\begin{array}{l}\text { Hut } \\
\text { No. }\end{array}$ & $\begin{array}{l}\text { Width of } \\
\text { External } \\
\text { Base (m) }\end{array}$ & $\begin{array}{c}\text { Interior } \\
\text { Diameter } \\
\text { (m) }\end{array}$ & $\begin{array}{l}\text { Interior } \\
\text { Area }\left(\mathbf{m}^{2}\right) \\
\text { (based on } \\
\text { diameter) }\end{array}$ & $\begin{array}{c}\text { Opening } \\
\text { Orientation }\end{array}$ & $\begin{array}{l}\text { Associated } \\
\text { Cultural Material }\end{array}$ & $\begin{array}{l}\text { Surface } \\
\text { Wood } \\
\text { (present } \\
\text { /absent) }\end{array}$ & Description & Type & Radiocarbon Age/s (BP) \\
\hline $\begin{array}{c}\text { Hut } \\
4\end{array}$ & 6.8 & 2.7 & 5.73 & nil & $\begin{array}{l}\text { Large fragments of } \\
\text { mussel shell }\end{array}$ & present & $\begin{array}{l}\text { The largest stones of this hut are } \sim 30 \mathrm{~cm} \text { in diameter. } \\
\text { Large scattered hut base with many large stones (more } \\
\text { than any other hut). Stones seem to be in two concentric } \\
\text { rings, altogether may be an artefact of subsequent } \\
\text { movement. Mound centre is } \sim 15 \mathrm{~cm} \text { high. Gidgee boughs } \\
\text { present on surface and the orientation of the opening is } \\
\text { difficult to pinpoint. Interior of mound honeycombed with } \\
\text { animal burrows under collapsed gidgee boughs. Mound in } \\
\text { centre is most likely a result of animal burrowing rather } \\
\text { than cultural. Apparent second ring of stone at this hut is } \\
\text { possibly the remainder of an older hut in the same } \\
\text { location. Hut } 14 \text { is a similar semi-circular ring } \\
\text { immediately southwest of Hut } 4 \text {. }\end{array}$ & 1 & $185 \pm 28$ (surface wood) \\
\hline $\begin{array}{l}\text { Hut } \\
5\end{array}$ & 4.3 & 2 & 3.14 & $\begin{array}{l}348^{\circ} \\
\text { (north) }\end{array}$ & $\begin{array}{l}\text { Large fragments of } \\
\text { mussel shell; } \\
\text { chalcedony and } \\
\text { silcrete stone } \\
\text { artefacts }\end{array}$ & present & $\begin{array}{l}\text { Slightly mounded hut base }(\sim 10 \mathrm{~cm}) \text { with soft sediment } \\
\text { accumulated in the middle. Low pebbled mound with large } \\
\text { stones (largest are } \sim 30 \mathrm{~cm} \text { in diameter) and with a } \\
\text { collapsed gidgee bough superstructure on top. }\end{array}$ & 1 & $\begin{array}{l}13 \pm 25 \text { (surface wood) } \\
154 \pm 21 \text { (Hut5E SqA XU3c shell) } \\
159 \pm 16 \text { (Hut5E SqA XU3c charcoal) } \\
225 \pm 21 \text { (Hut5E SqA XU4 shell) } \\
201 \pm 16 \text { (Hut5E SqA XU4 charcoal) }\end{array}$ \\
\hline $\begin{array}{l}\text { Hut } \\
6\end{array}$ & 5.3 & $\begin{array}{l}\text { could } \\
\text { not be } \\
\text { measure } \\
\text { d }\end{array}$ & $\begin{array}{l}\text { could not } \\
\text { be } \\
\text { measured }\end{array}$ & nil & $\begin{array}{l}\text { Large fragments of } \\
\text { mussel shell }\end{array}$ & absent & $\begin{array}{l}\text { Raised mound with many large stones (largest are } \sim 30 \mathrm{~cm} \\
\text { in diameter) but dispersed. Mound is } \sim 15 \mathrm{~cm} \text { high. } \\
\text { Opening is difficult to determine but possibly to the west. }\end{array}$ & 3 & nil \\
\hline $\begin{array}{l}\text { Hut } \\
7\end{array}$ & 3.8 & 2.2 & 3.8 & $\begin{array}{c}314^{\circ} \\
\text { (northwest) }\end{array}$ & $\begin{array}{l}\text { Few small mussel } \\
\text { shell fragments; } \\
\text { flaked silcrete; } \\
\text { flaked structural } \\
\text { material }\end{array}$ & absent & $\begin{array}{l}\text { Semi-deflated interior with high mound sides in two } \\
\text { separate semi-circular halves. Large stone are } \sim 30 \mathrm{~cm} \text { in } \\
\text { diameter. Some large stones have been knapped but are } \\
\text { also structural. }\end{array}$ & 2 & nil \\
\hline $\begin{array}{l}\text { Hut } \\
8\end{array}$ & 3.2 & 1.5 & 1.77 & $\begin{array}{c}20^{\circ} \\
\text { (north) }\end{array}$ & $\begin{array}{l}\text { Large silcrete flakes } \\
\text { and cores (some of } \\
\text { which are } \\
\text { structural) }\end{array}$ & absent & $\begin{array}{l}\text { Substantially intact hut with many large stones }(\sim 30 \mathrm{~cm} \text { in } \\
\text { diameter). Large stones are dispersed to the west thus } \\
\text { western extremity is difficult to define. }\end{array}$ & 2 & nil \\
\hline
\end{tabular}


Appendix A. Summary information about huts recorded at HCS1 (cont.).

\begin{tabular}{|c|c|c|c|c|c|c|c|c|c|}
\hline $\begin{array}{c}\text { Hut } \\
9\end{array}$ & 3.2 & 1.5 & 1.77 & nil & $\begin{array}{l}\text { Chalcedony and } \\
\text { small silcrete flakes; } \\
\text { large flaked silcrete } \\
\text { cobbles used } \\
\text { structurally }\end{array}$ & absent & $\begin{array}{l}\text { Semi-deflated base with some large stones on northeast } \\
\text { edge but less than Hut } 8 \text {. No obvious opening present. }\end{array}$ & 2 & nil \\
\hline $\begin{array}{c}\text { Hut } \\
10\end{array}$ & 3.2 & 1 & 0.79 & $\begin{array}{c}294^{\circ} \\
\text { (northwest) }\end{array}$ & $\begin{array}{l}\text { Flaked stone } \\
\text { artefacts; flaked } \\
\text { structural material }\end{array}$ & absent & $\begin{array}{l}\text { A deflated older hut base immediately north and lower to } \\
\text { Hut } 7 \text {. The stone from Huts } 7 \text { and } 10 \text { blend into each other } \\
\text { so it is difficult to separate them clearly. }\end{array}$ & 2 & nil \\
\hline $\begin{array}{c}\text { Hut } \\
11\end{array}$ & b) 4 & b) 2 & 3.14 & north & $\begin{array}{l}\text { Large fragments of } \\
\text { mussel shell; flaked } \\
\text { stone artefacts, } \\
\text { including } \\
\text { chalcedony }\end{array}$ & absent & $\begin{array}{l}\text { Curvature of stones suggests that this area contains two } \\
\text { separate huts, with their opening most likely to the north } \\
\text { given the curvature and assuming the remaining stones } \\
\text { once made up the rear wall bases. Structure (a) is unable to } \\
\text { be measured as the section of wall still preserved is too } \\
\text { short. }\end{array}$ & 2 & nil \\
\hline $\begin{array}{c}\text { Hut } \\
12\end{array}$ & 3.5 & 1.7 & 2.27 & nil & $\begin{array}{l}\text { Large fragments of } \\
\text { mussel shell; } \\
\text { chalcedony and } \\
\text { silcrete flakes }\end{array}$ & absent & $\begin{array}{l}\text { Highly dispersed hut base with the most intact section } \\
\text { along the western edge. }\end{array}$ & 2 & nil \\
\hline $\begin{array}{c}\text { Hut } \\
13\end{array}$ & 4.5 & 2.3 & 4.15 & $\begin{array}{c}332^{\circ} \\
\text { (northwest) }\end{array}$ & $\begin{array}{l}\text { Silcrete flakes and } \\
\text { cores }\end{array}$ & absent & $\begin{array}{l}\text { Highly deflated and dispersed base with no large stones } \\
\text { and stones scattered over a wide area. }\end{array}$ & 3 & nil \\
\hline $\begin{array}{c}\text { Hut } \\
14\end{array}$ & 4.3 & 1.6 & 2.01 & nil & $\begin{array}{l}\text { Large flaked silcrete } \\
\text { artefacts }\end{array}$ & absent & $\begin{array}{l}\text { A semi-circular shaped hut base; there may be an older } \\
\text { base in the same location. }\end{array}$ & 2 & nil \\
\hline $\begin{array}{c}\text { Hut } \\
15\end{array}$ & 3.8 & 1.8 & 2.54 & nil & $\begin{array}{l}\text { Large flaked silcrete } \\
\text { artefacts; } \\
\text { chalcedony flake }\end{array}$ & absent & $\begin{array}{l}\text { Highly deflated base, composed mainly of small stones } \\
\text { (pebbles), the largest of which are } \sim 20 \mathrm{~cm} \text { in diameter but } \\
\text { most average } 10-12 \mathrm{~cm} \text {. The opening is difficult to } \\
\text { determine because of deflation. }\end{array}$ & 3 & nil \\
\hline $\begin{array}{c}\text { Hut } \\
16\end{array}$ & 3.3 & 2 & 3.14 & $\begin{array}{c}42^{\circ} \\
\text { (northeast) }\end{array}$ & $\begin{array}{l}\text { Large silcrete flakes } \\
\text { and cores (many of } \\
\text { which are } \\
\text { structural) }\end{array}$ & absent & $\begin{array}{l}\text { Located south of Hut } 1 \text {, this hut base is very broken up } \\
\text { with the most preserved section on the northeast side. The } \\
\text { base is still recognisable as being circular in shape, } \\
\text { although dispersed and deflated in the centre. }\end{array}$ & 3 & nil \\
\hline
\end{tabular}


Appendix B. Lithic artefact raw materials recovered from Hut 1 and Hut 5, HCS1.

\begin{tabular}{|c|c|c|c|c|c|c|}
\hline Site & $\mathbf{X U}$ & Silcrete & Quartz & Chert & Chalcedony & Total \\
\hline \multirow{8}{*}{ Hut 1} & 1 & 6 & & 1 & & 7 \\
\hline & 2 & 2 & 1 & & & 3 \\
\hline & 3 & & & & & \\
\hline & 4 & 2 & & 1 & & 3 \\
\hline & 5 & 4 & & & & 4 \\
\hline & 6 & 1 & 1 & 1 & & 3 \\
\hline & 7 & & & & & \\
\hline & Total & 15 & 2 & 3 & & 20 \\
\hline \multirow{8}{*}{ Hut 5} & 1 & 32 & 20 & 21 & 2 & 75 \\
\hline & 2 & 2 & 2 & 3 & & 7 \\
\hline & 3 & 4 & 1 & 1 & & 6 \\
\hline & 4 & & & & & \\
\hline & 5 & & & & & \\
\hline & 6 & & & & & \\
\hline & 7 & & & & & \\
\hline & Total & 38 & 23 & 25 & 2 & 88 \\
\hline
\end{tabular}

Appendix C. Faunal remains from Hut 1 and Hut 5, HCS1.

\begin{tabular}{|c|c|c|c|c|c|}
\hline Site & XU & Bone (g) & MNI & Identifying element & Order/Genus \\
\hline \multirow{4}{*}{ Hut 1 } & 2 & 0.50 & 1 & Proximal femur (L) & Rodentia \\
\cline { 2 - 6 } & 3 & 0.49 & 1 & Caudal vertebrae & Rodentia \\
\cline { 2 - 6 } & 4 & 0.79 & 1 & Mandible with molars & Notomys \\
\cline { 2 - 6 } & 5 & 1.00 & 1 & Proximal humerus & Rodentia \\
\cline { 2 - 6 } & 6 & 0.56 & 1 & Proximal femur (R) & Crustacea \\
\cline { 2 - 6 } & 6 & 0.03 & 1 & Exoskeleton & Rodentia \\
\cline { 2 - 6 } & 7 & 0.21 & 1 & Lower incisor & Rodentia \\
\hline Hut 5E & 1 & 0.80 & 1 & Upper incisor & Reptilia/Lacertilia \\
\cline { 2 - 6 } & 2 & 0.68 & 1 & Distal humerus (L) & Rodentia \\
\cline { 2 - 6 } & 2 & 0.15 & 1 & Vertebrae & Upper incisor \\
\cline { 2 - 6 }
\end{tabular}


Appendix D. Summary of grinding stones recovered from HCS1.

\begin{tabular}{|c|c|c|c|c|c|c|c|}
\hline $\begin{array}{l}\text { Unique } \\
\text { ID }\end{array}$ & Material & $\begin{array}{c}\begin{array}{c}\text { Length } \\
(\mathrm{mm})\end{array} \\
\end{array}$ & $\begin{array}{l}\text { Width } \\
(\mathrm{mm})\end{array}$ & $\begin{array}{c}\text { Thickness } \\
(\mathrm{mm})\end{array}$ & $\begin{array}{c}\text { Weight } \\
\text { (g) }\end{array}$ & $\begin{array}{c}\text { Morphological } \\
\text { Type }\end{array}$ & $\begin{array}{c}\text { Number of Ground } \\
\text { Surfaces }\end{array}$ \\
\hline 1 & Sandstone & 73.46 & 55.78 & 18.71 & 109.08 & Pestle & 1 \\
\hline 2 & Sandstone & 98.45 & 71.21 & 24.90 & 241.29 & Pestle & 2 \\
\hline 3 & Sandstone & 106.57 & 84.59 & 28.51 & 270.95 & Pestle & 1 \\
\hline 4 & Sandstone & 148.89 & 76.00 & 22.47 & 292.71 & Pestle & 2 \\
\hline 5 & Sandstone & 65.58 & 64.71 & 19.22 & 130.77 & Pestle & 1 \\
\hline 6 & Sandstone & 103.88 & 75.83 & 22.43 & 157.96 & Pestle & 1 \\
\hline 7 & Sandstone & 101.42 & 82.27 & 29.58 & 292.61 & Pestle & 2 \\
\hline 8 & Sandstone & 61.47 & 42.85 & 14.70 & 44.35 & Pestle & 2 \\
\hline 9 & Sandstone & 61.38 & 57.64 & 15.68 & 62.68 & Pestle & 2 \\
\hline 10 & Sandstone & 124.86 & 99.54 & 29.8 & 417.37 & Pestle & 2 \\
\hline 11 & Sandstone & 109.05 & 104.95 & 46.07 & 507.46 & Pestle & 1 \\
\hline 12 & Fine grained sandstone & 80.19 & 54.63 & 26.51 & 144.78 & Unclear & 2 \\
\hline 13 & Sandstone & 118.22 & 97.71 & 30.53 & 389.23 & Unclear & 1 \\
\hline 14 & Sandstone & 98.27 & 60.00 & 24.64 & 121.53 & Unclear & 2 \\
\hline 15 & Sandstone & 56.32 & 25.85 & 10.88 & 14.16 & Mortar & 1 \\
\hline 16 & Sandstone & 107.81 & 57.49 & 27.32 & 168.93 & Pestle & 1 \\
\hline 17 & Sandstone & 100.45 & 70.55 & 40.41 & 327.73 & Unclear & 1 \\
\hline 18 & Sandstone & 117.56 & 97.88 & 57.14 & 524.59 & Mortar & 1 \\
\hline 19 & Sandstone & 102.66 & 71.24 & 17.28 & 105.65 & Mortar & 2 \\
\hline 20 & Sandstone & 90.23 & 55.05 & 28.75 & 166.96 & Unclear & 2 \\
\hline 21 & Sandstone & 48.43 & 47.21 & 12.80 & 35.64 & Pestle & 1 \\
\hline 22 & Sandstone & 153.76 & 89.47 & 55.78 & 985.48 & Pestle & 1 \\
\hline 23 & Sandstone & 58.37 & 39.26 & 11.45 & 41.43 & Unclear & 1 \\
\hline 24 & Sandstone & 41.90 & 30.13 & 14.97 & 25.28 & Pestle & 1 \\
\hline 25 & Sandstone & 89.53 & 60.53 & 17.71 & 123.52 & Unclear & 2 \\
\hline 26 & Sandstone & 64.53 & 58.11 & 10.80 & 51.07 & Unclear & 2 \\
\hline 27 & Sandstone & 87.28 & 72.28 & 45.30 & 387.01 & Pestle & 1 \\
\hline 28 & Sandstone & 47.94 & 46.79 & 23.22 & 75.83 & Pestle & 1 \\
\hline 29 & Sandstone & 45.86 & 34.79 & 14.95 & 24.88 & Unclear & 2 \\
\hline 30 & Sandstone & 64.33 & 40.36 & 13.06 & 33.03 & Unclear & 2 \\
\hline 31 & Sandstone & 47.71 & 36.75 & 14.63 & 33.86 & Pestle & 2 \\
\hline 32 & Sandstone & 70.89 & 61.75 & 50.43 & 285.52 & Pestle & 2 \\
\hline 33 & Sandstone & 82.06 & 77.22 & 66.44 & 701.94 & Pestle & 2 \\
\hline \multirow[t]{5}{*}{34} & Sandstone & 127.10 & 86.45 & 21.99 & 211.13 & Pestle & 1 \\
\hline & Average & 87.0 & 64.3 & 26.7 & 220.8 & & \\
\hline & Minimum & 41.9 & 25.9 & 10.8 & 14.2 & & \\
\hline & Maximum & 153.8 & 105.0 & 66.4 & 985.5 & & \\
\hline & Mean & 88.4 & 61.1 & 22.8 & 151.4 & & \\
\hline
\end{tabular}


Appendix E. Summary of stone arrangement types (after Fitzpatrick et al. 2018) at the Hilary Creek site complex.

\begin{tabular}{|l|c|c|c|}
\hline \multicolumn{1}{|c|}{ Structure Type } & HCS1 & HCS2 & HCS3 \\
\hline C-variant & & 2 & 1 \\
\hline Linear & 8 & 3 & 1 \\
\hline Outlined circle $(>3 \mathrm{~m})$ & 1 & 3 & 1 \\
\hline Filled circle $(<1 \mathrm{~m})$ & 11 & 2 & 3 \\
\hline Keyhole (dual linear and circle combination) & & 1 & \\
\hline Complex (single linear and circle combination) & & & 1 \\
\hline Total & $\mathbf{2 0}$ & $\mathbf{1 1}$ & $\mathbf{7}$ \\
\hline
\end{tabular}


Appendix F. Hut 1, HSC1.

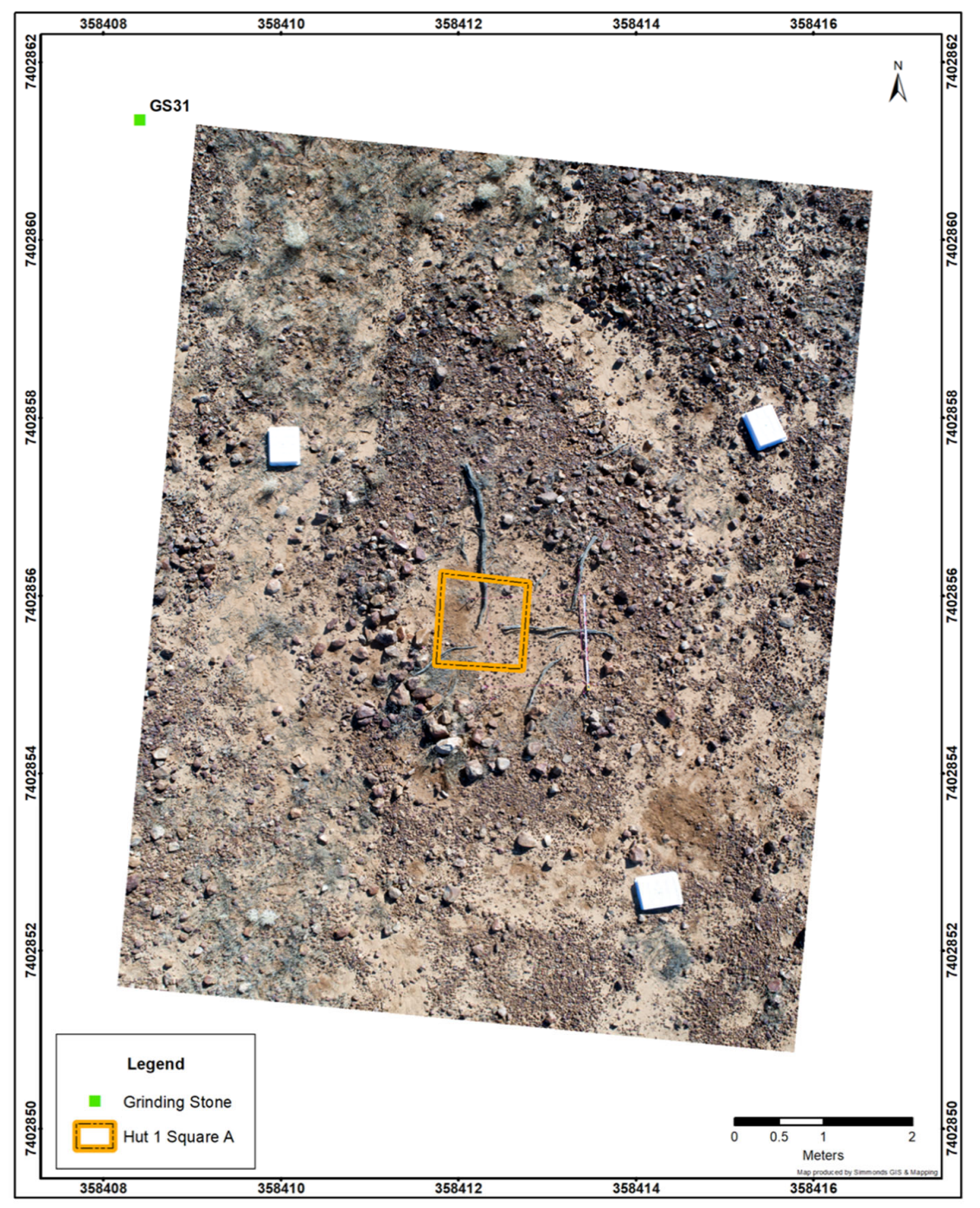

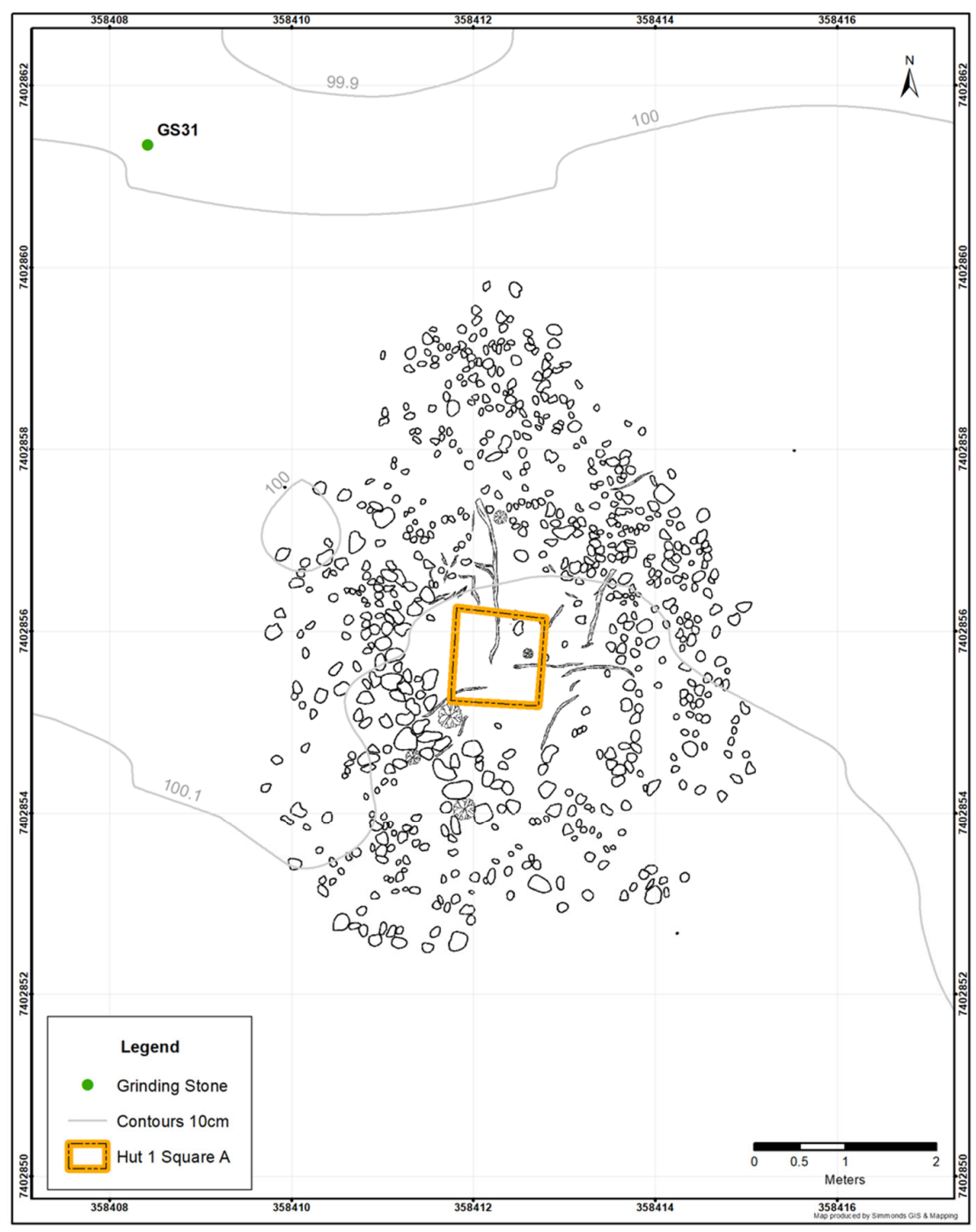


Appendix G. Hut 2, HSC1.

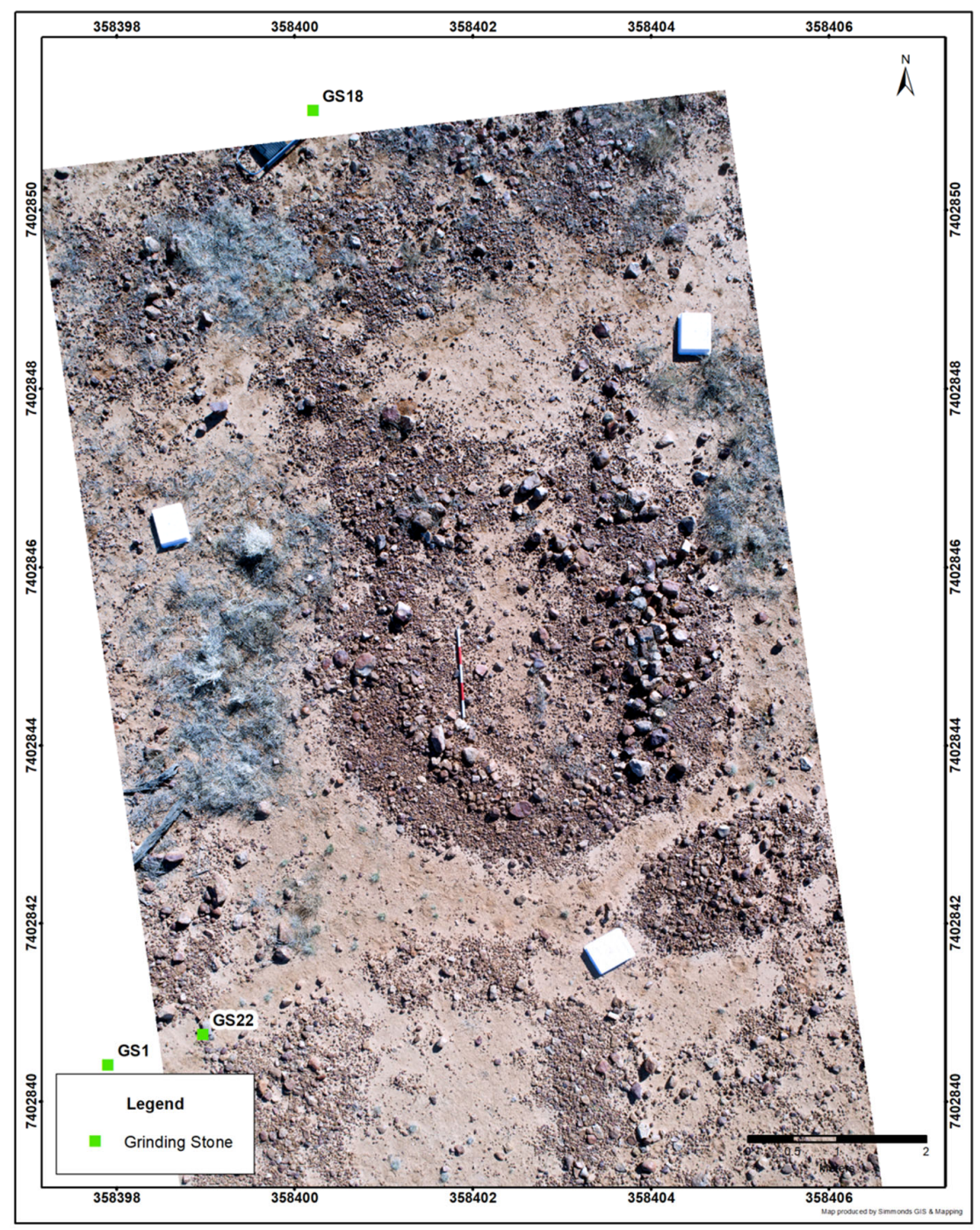

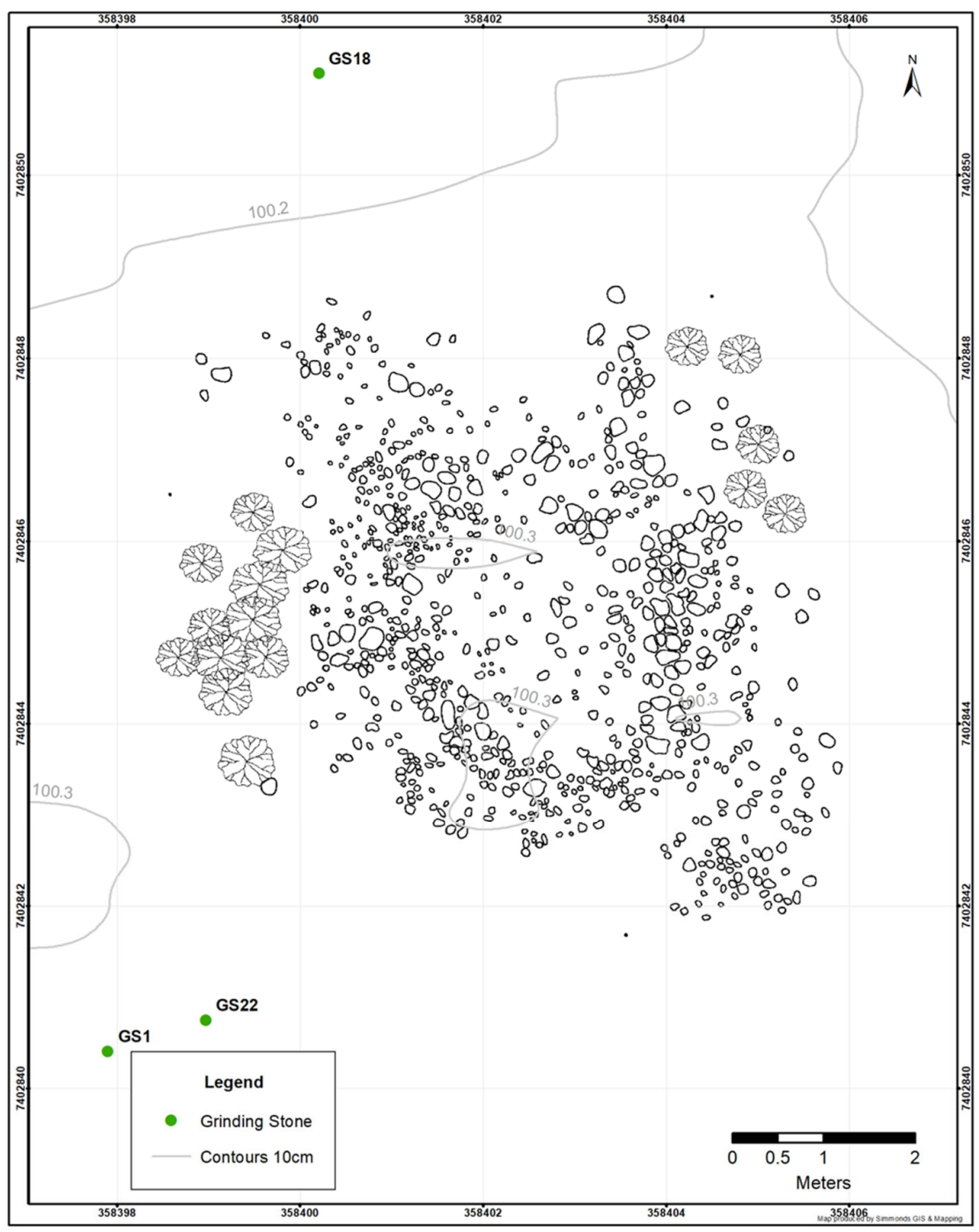


Appendix H. Hut 3, HSC1.

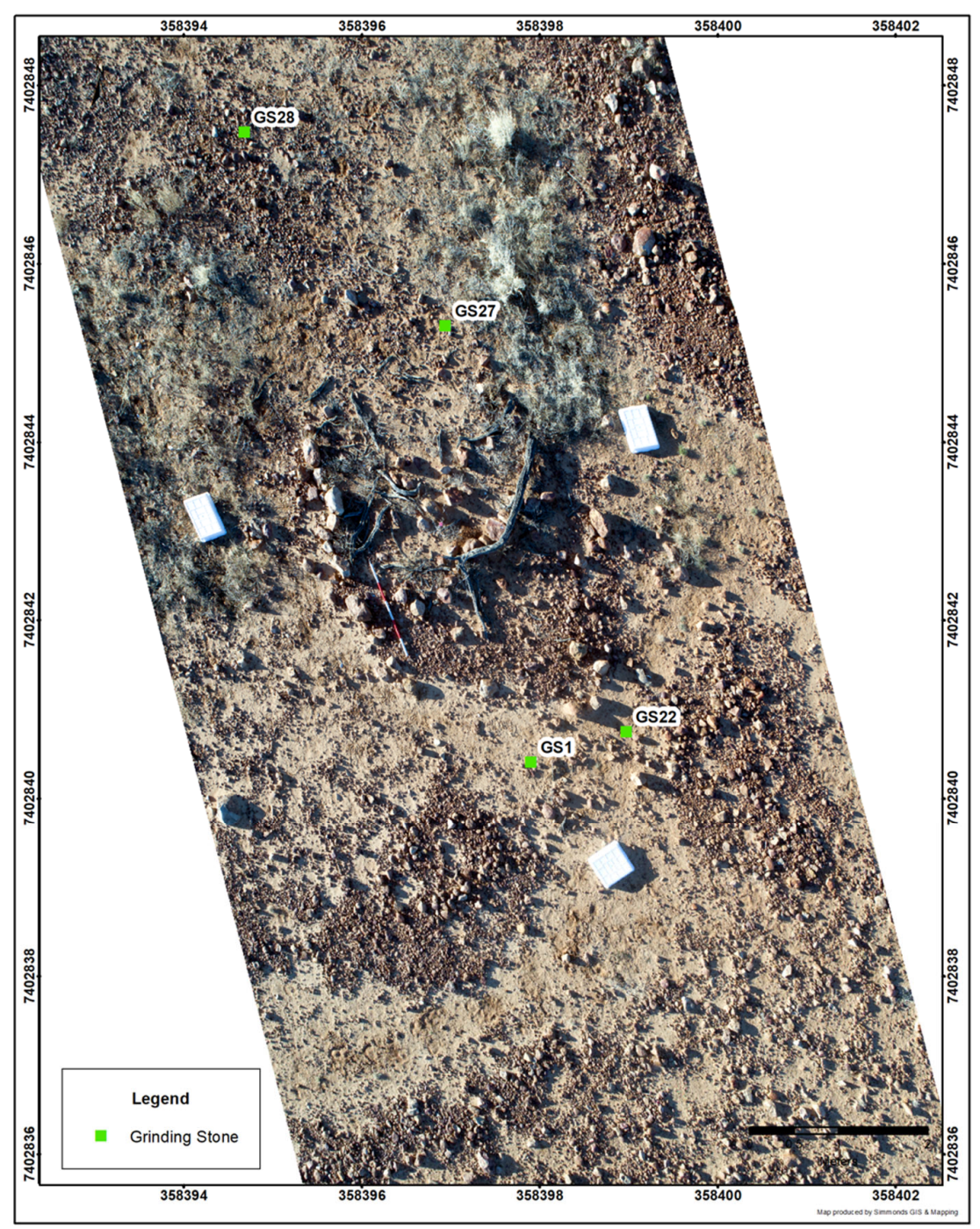

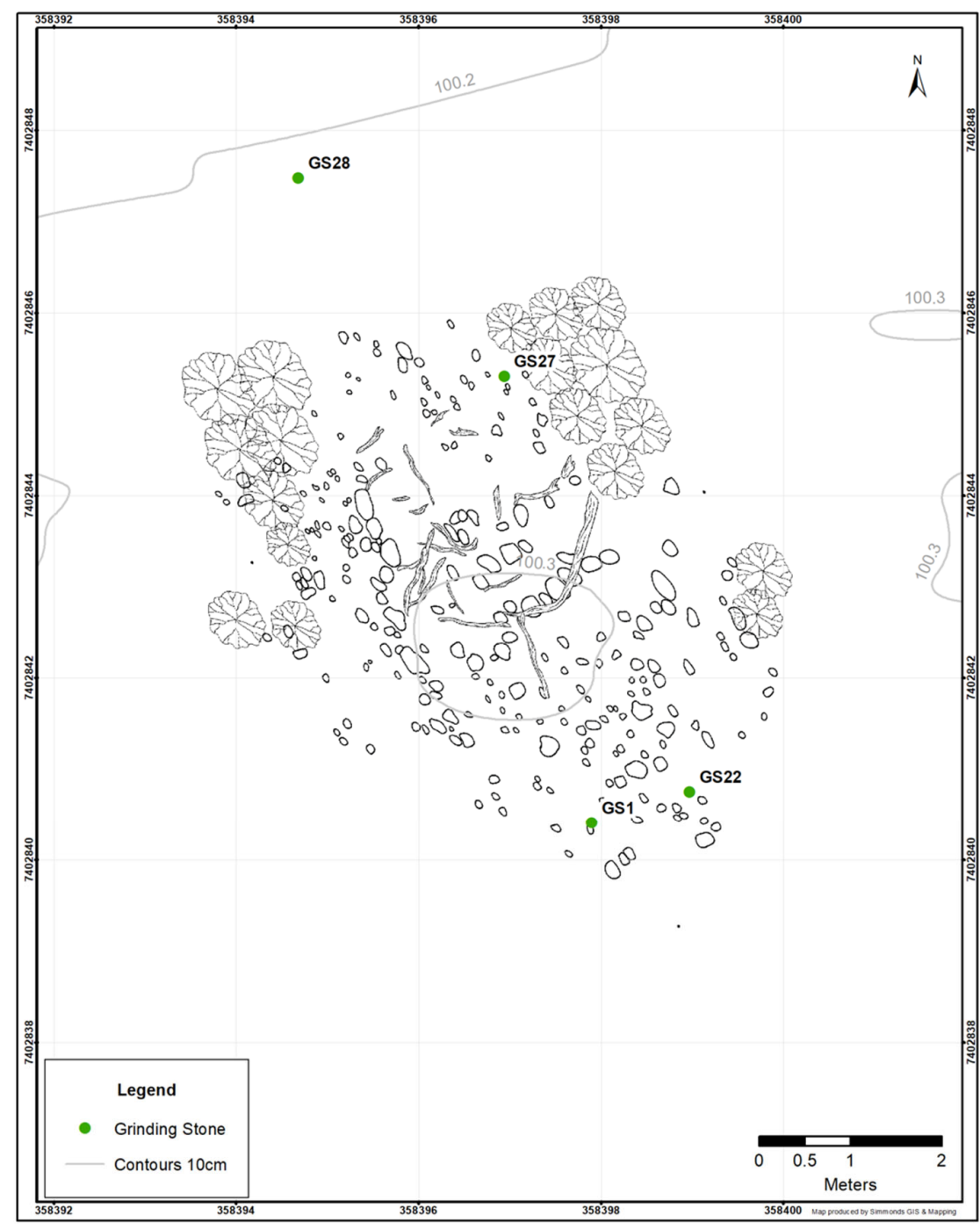


Appendix I. Hut 4, HSC1.

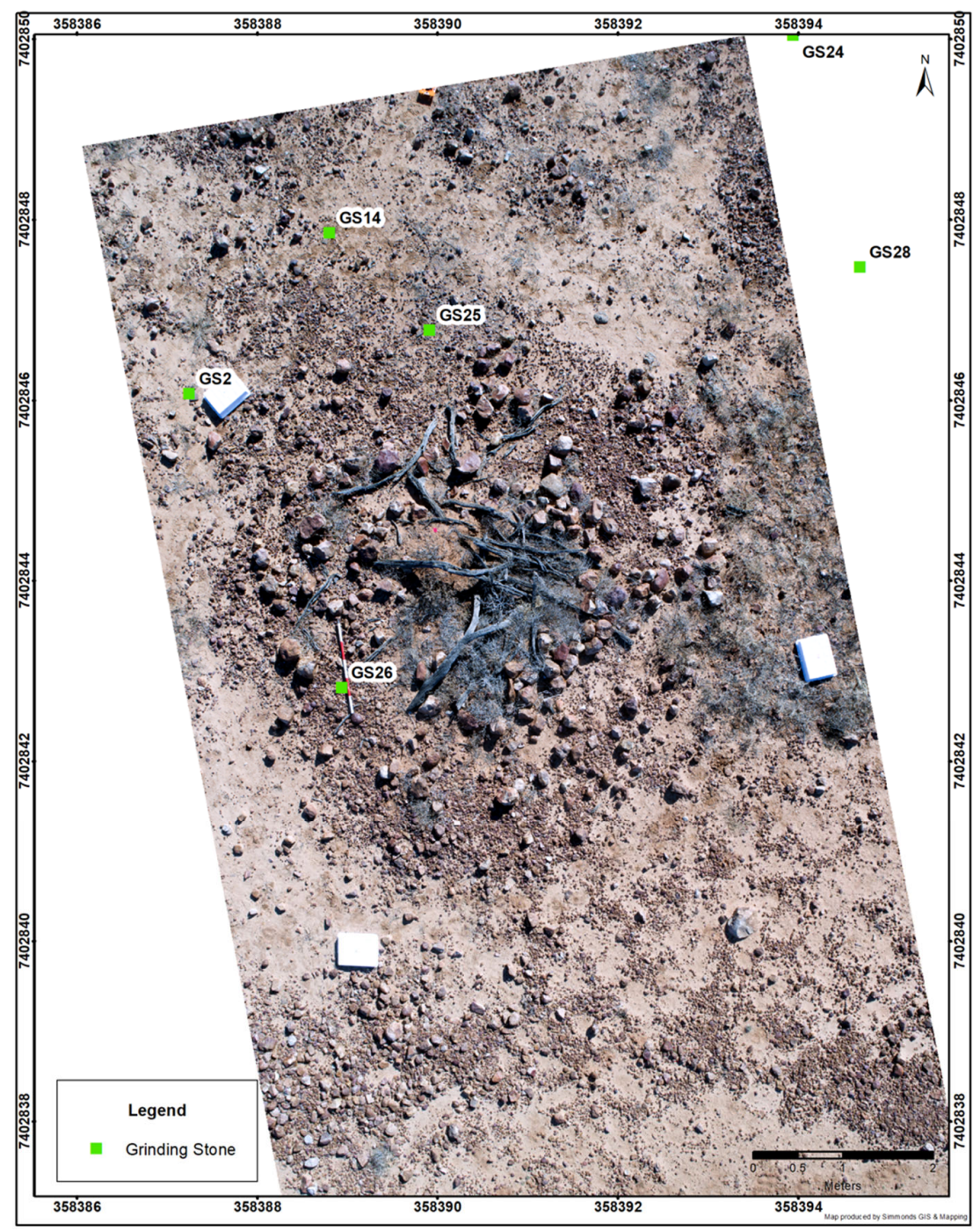

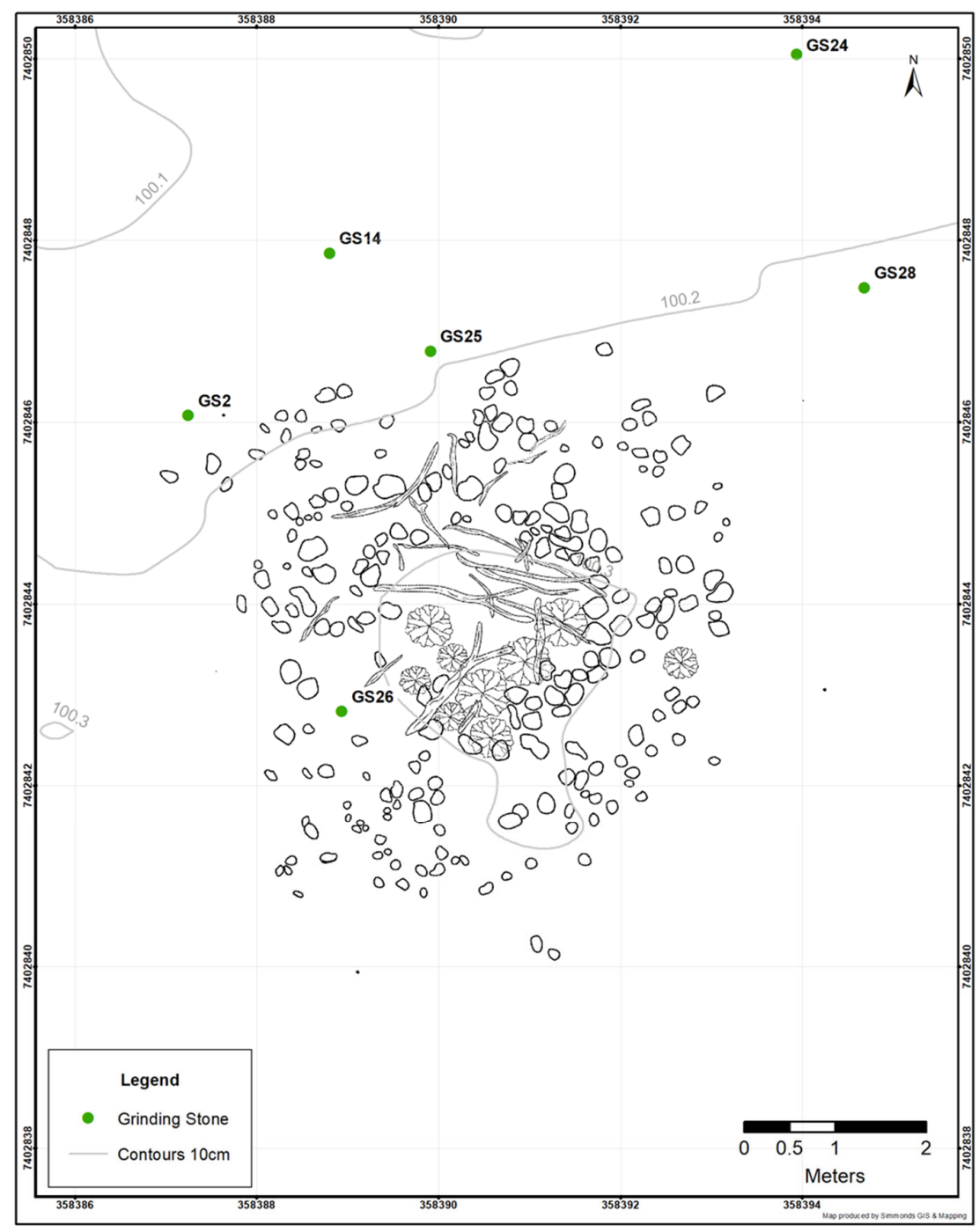



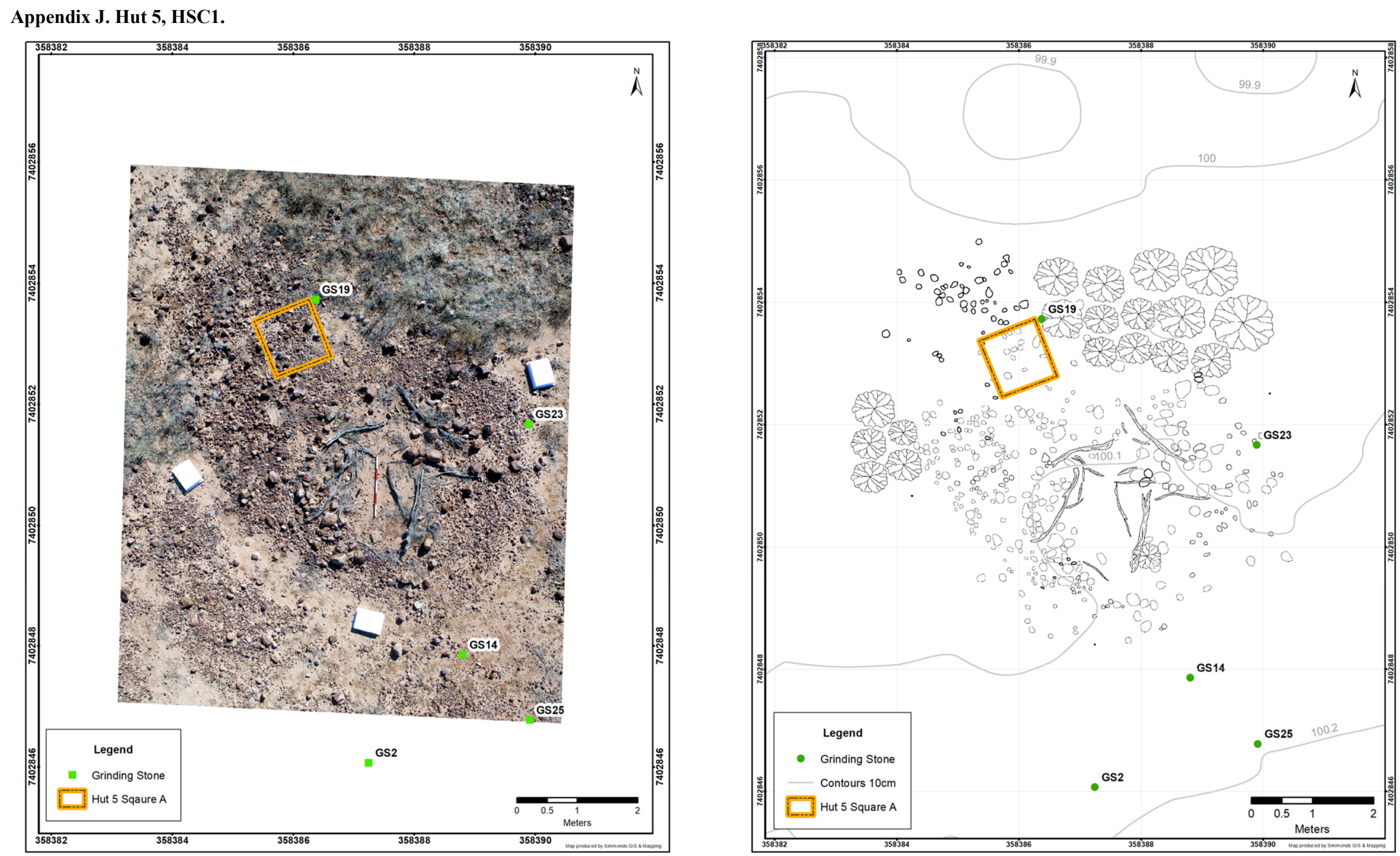
Appendix K. Hut 6, HSC1.

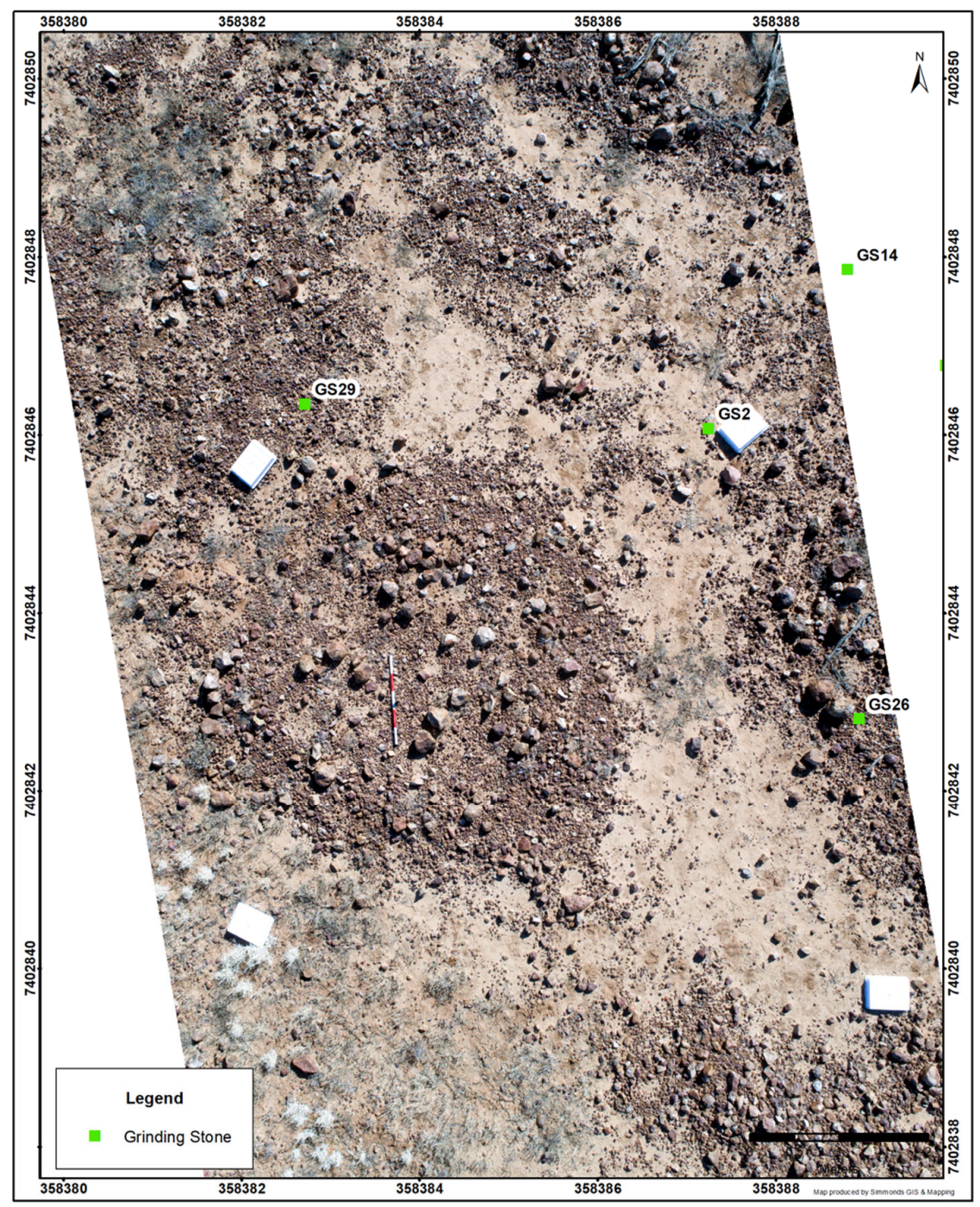

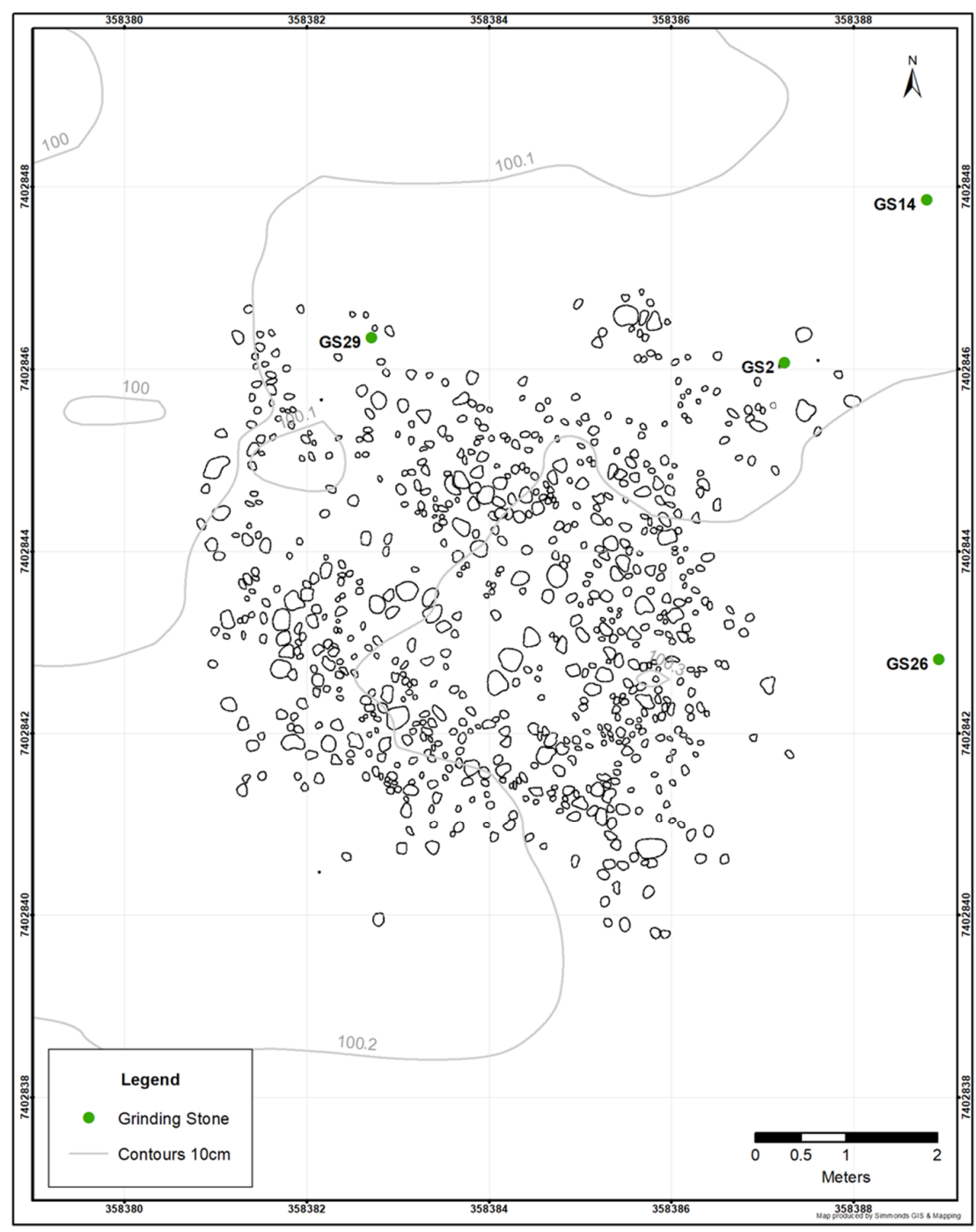


Appendix L. Huts 7 and 10, HSC1.

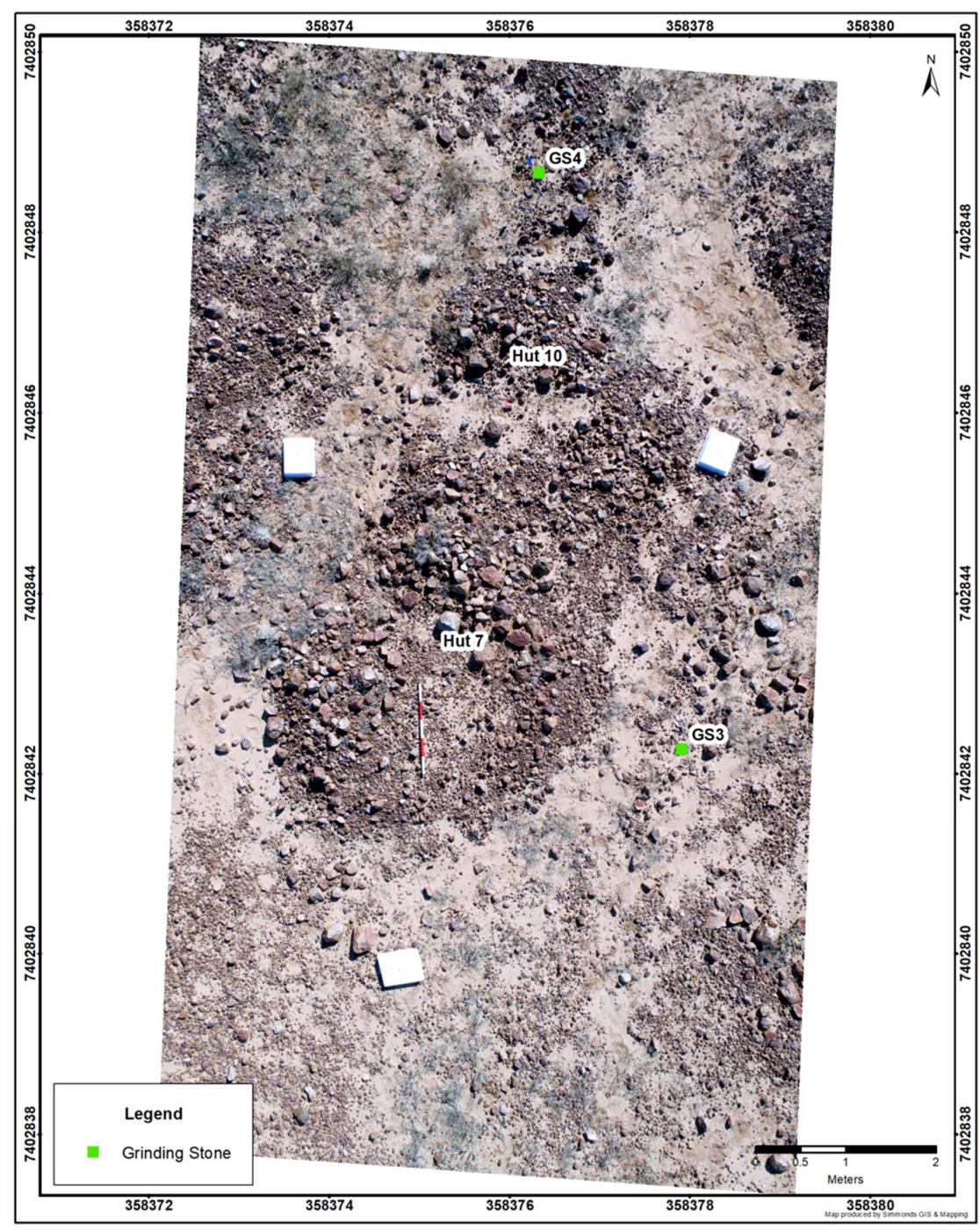

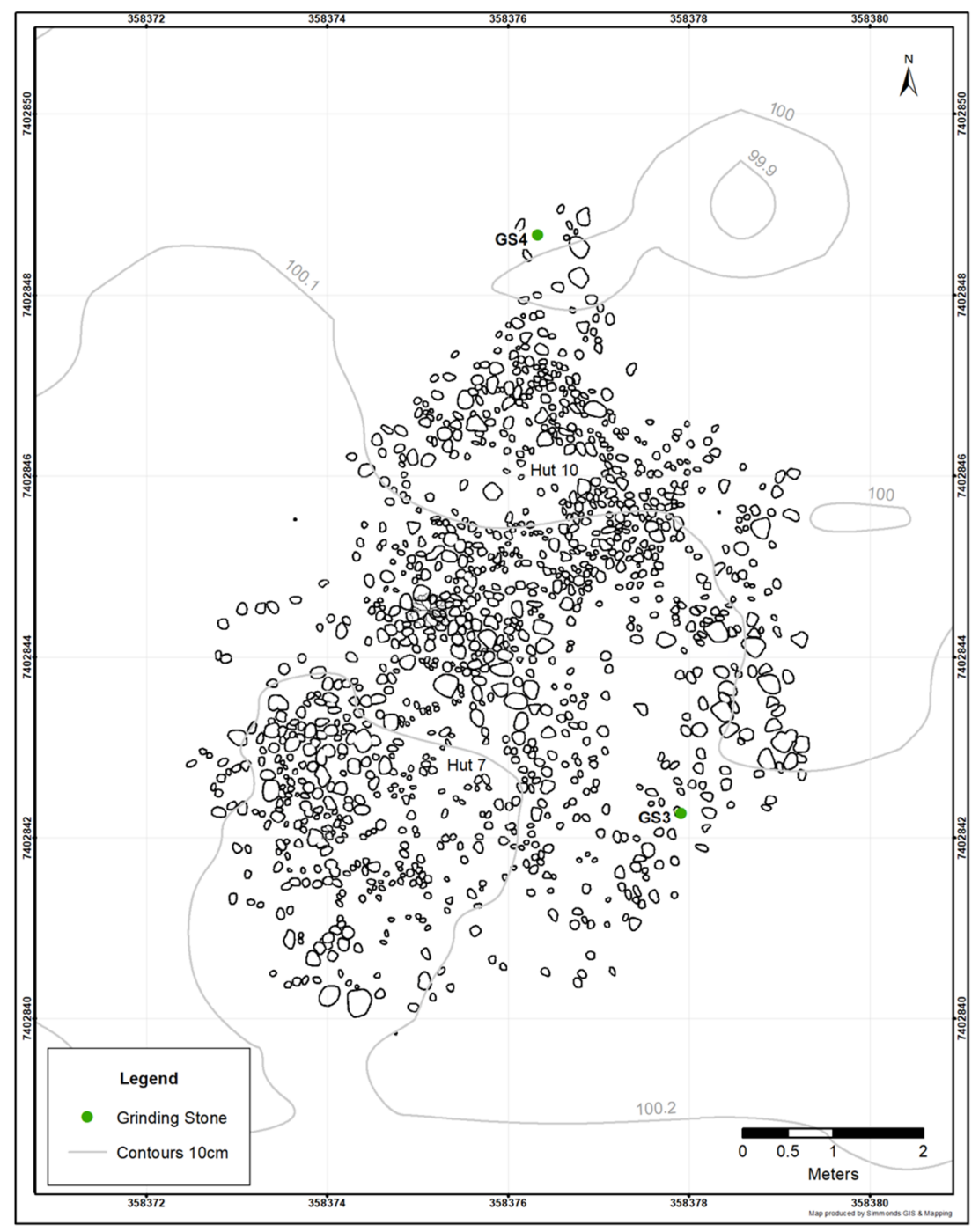


Appendix M. Hut 8, HSC1.

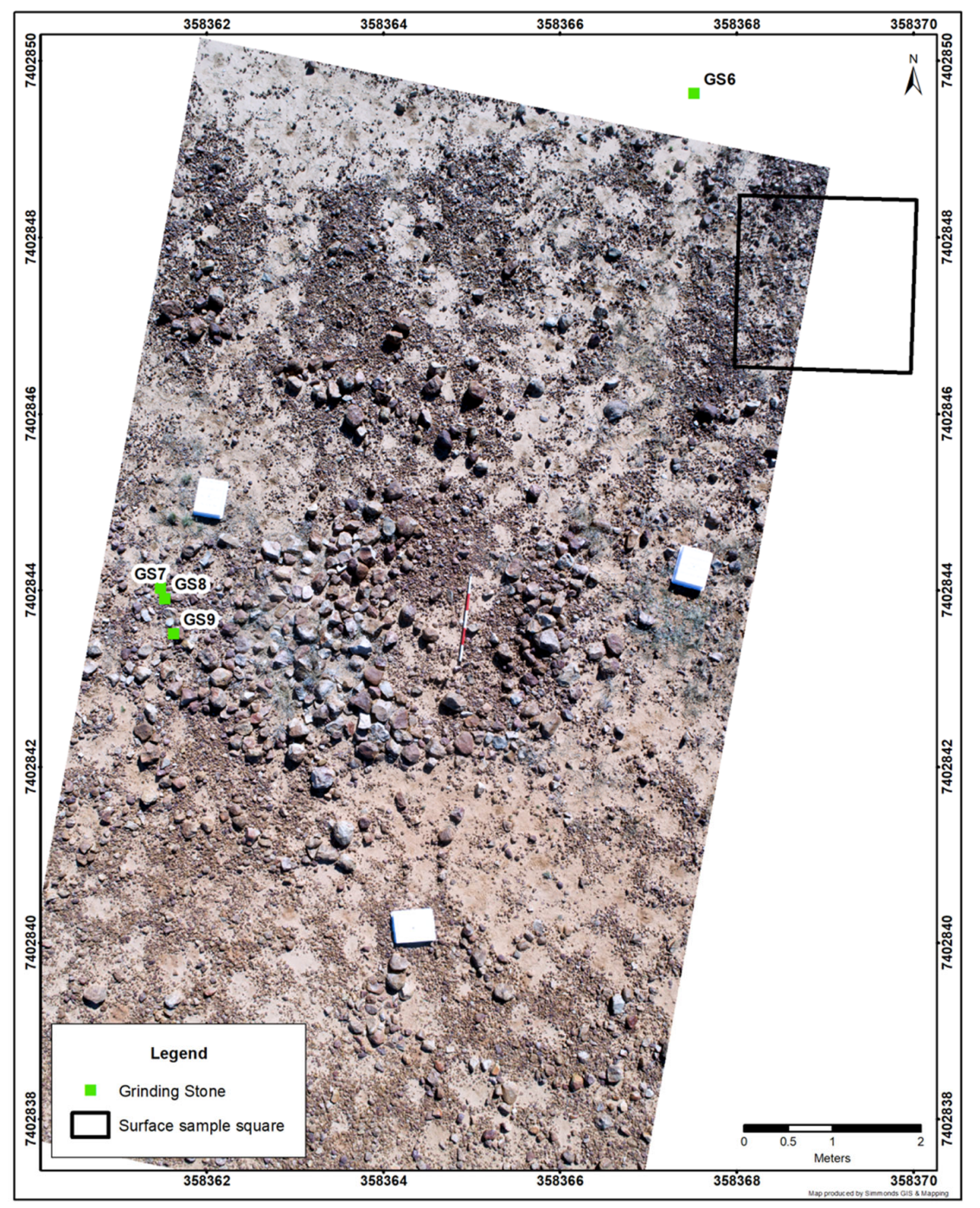

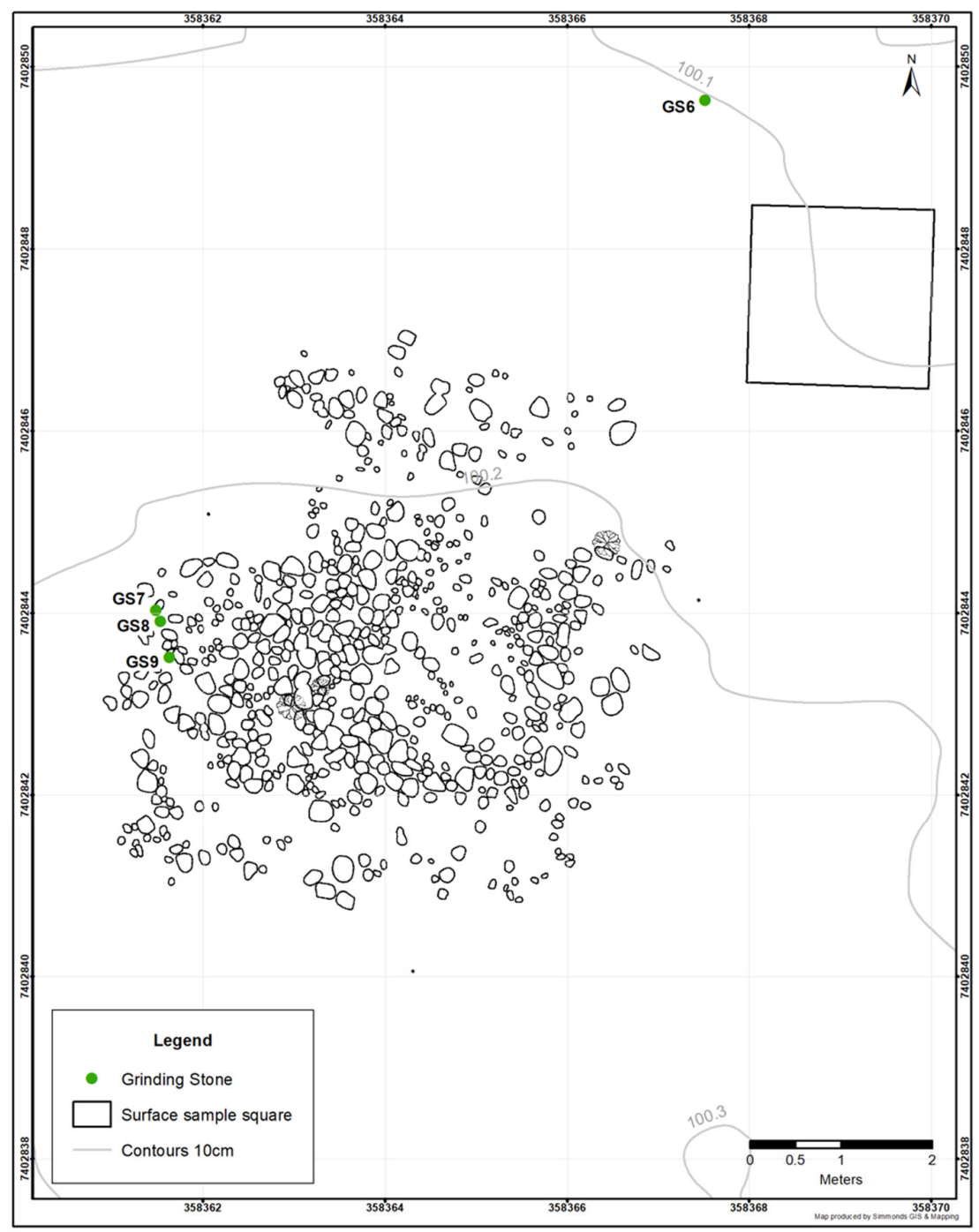


Appendix N. Hut 9, HSC1.
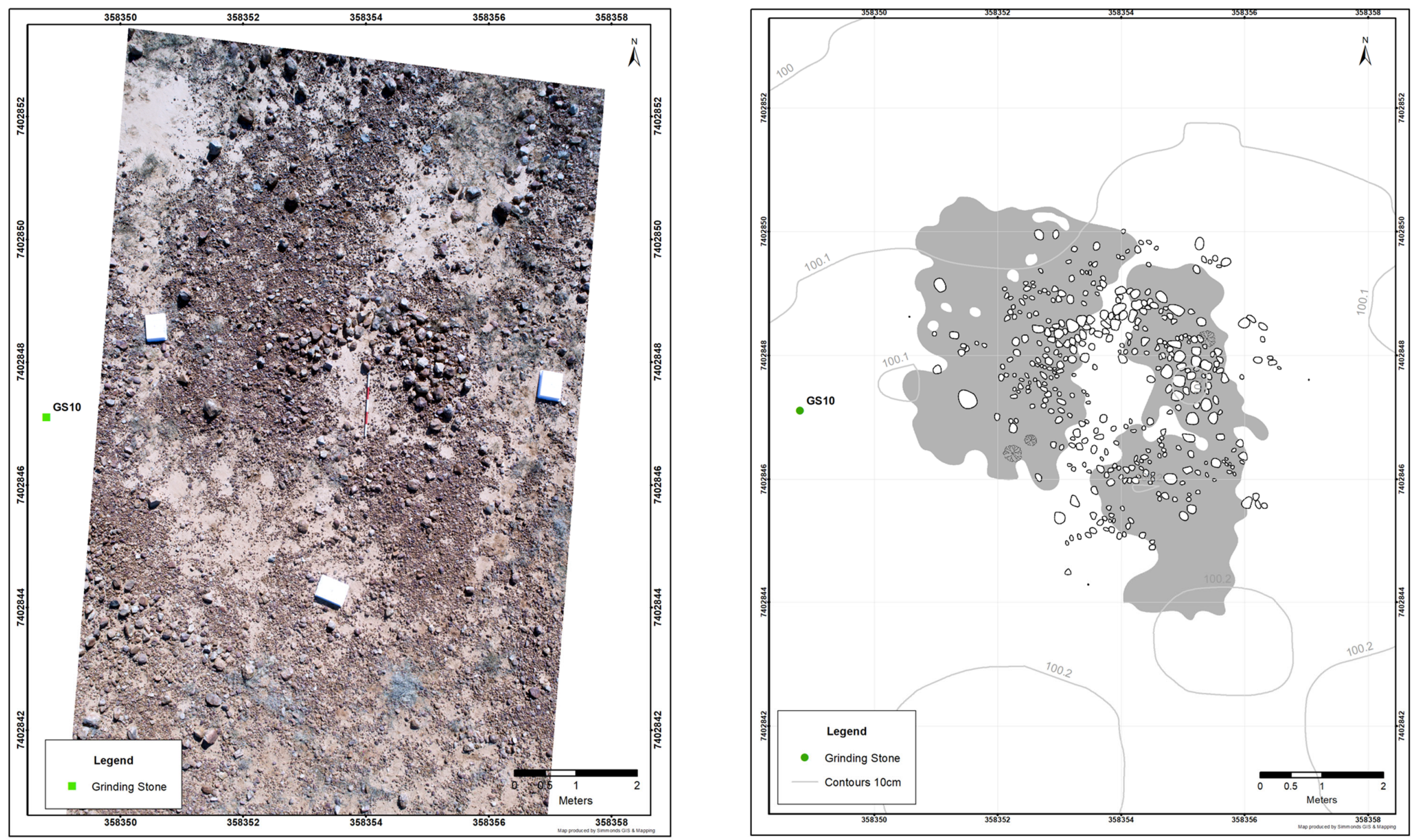
Appendix O. Hut 11, HSC1.

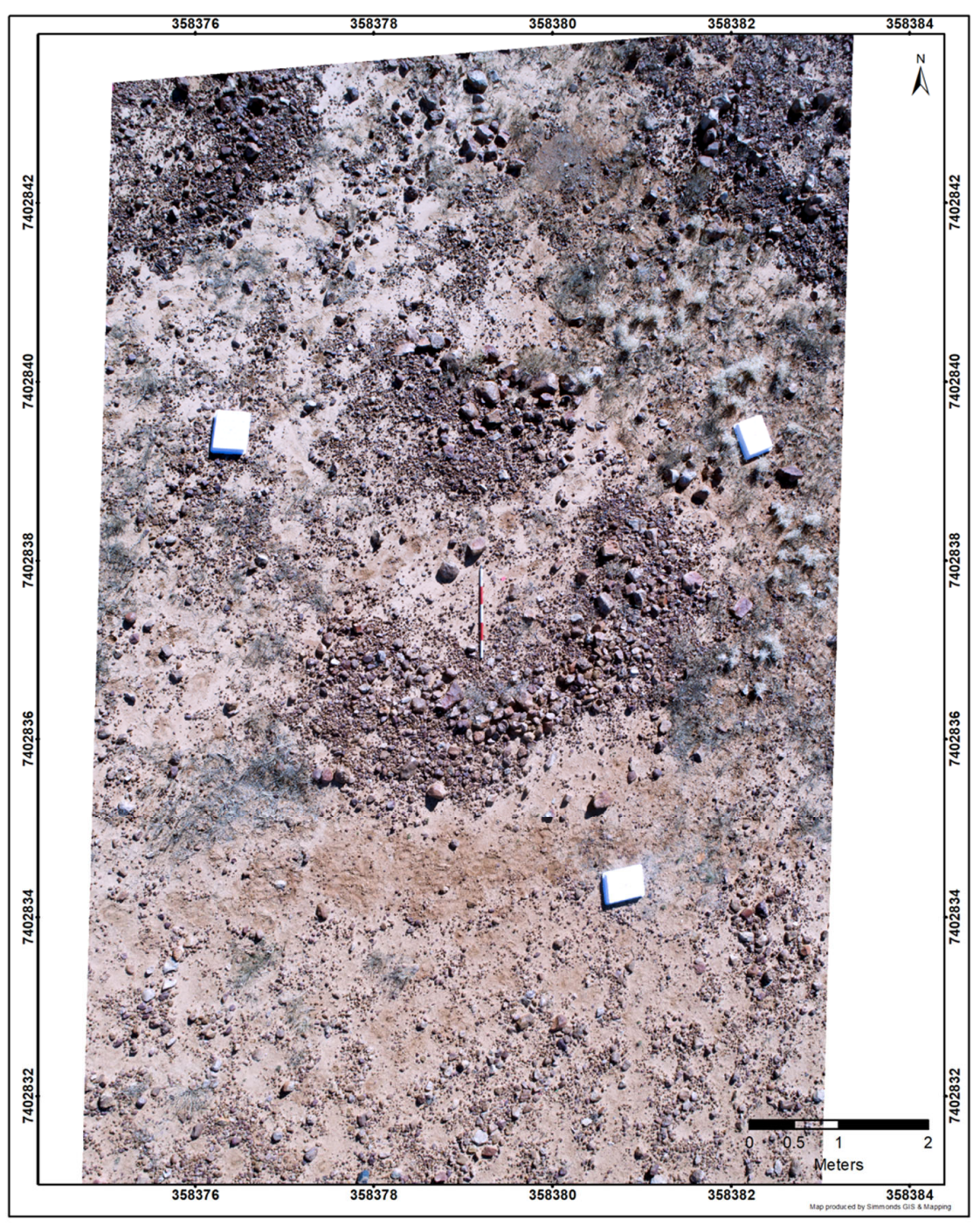

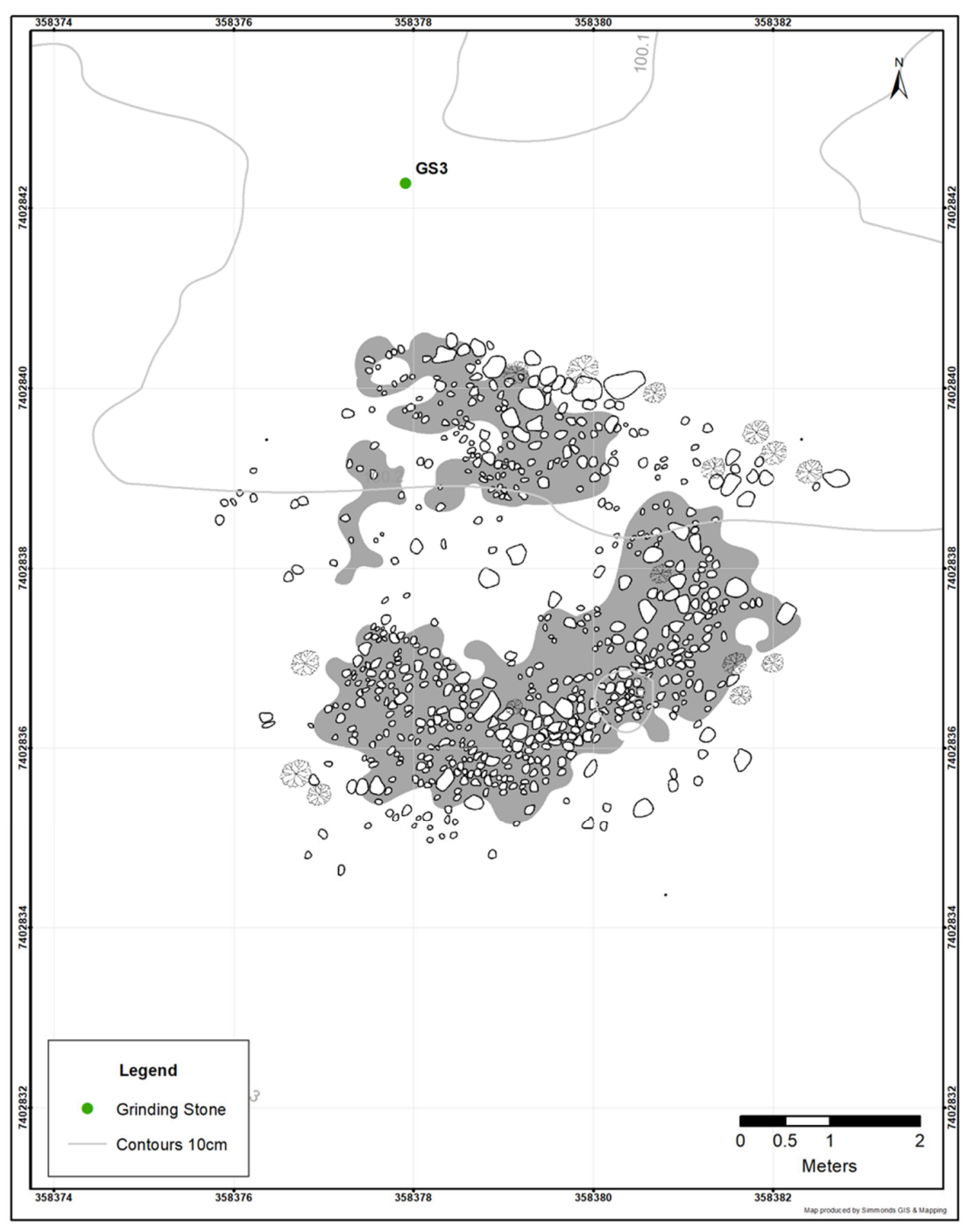


Appendix P. Hut 12, HSC1.
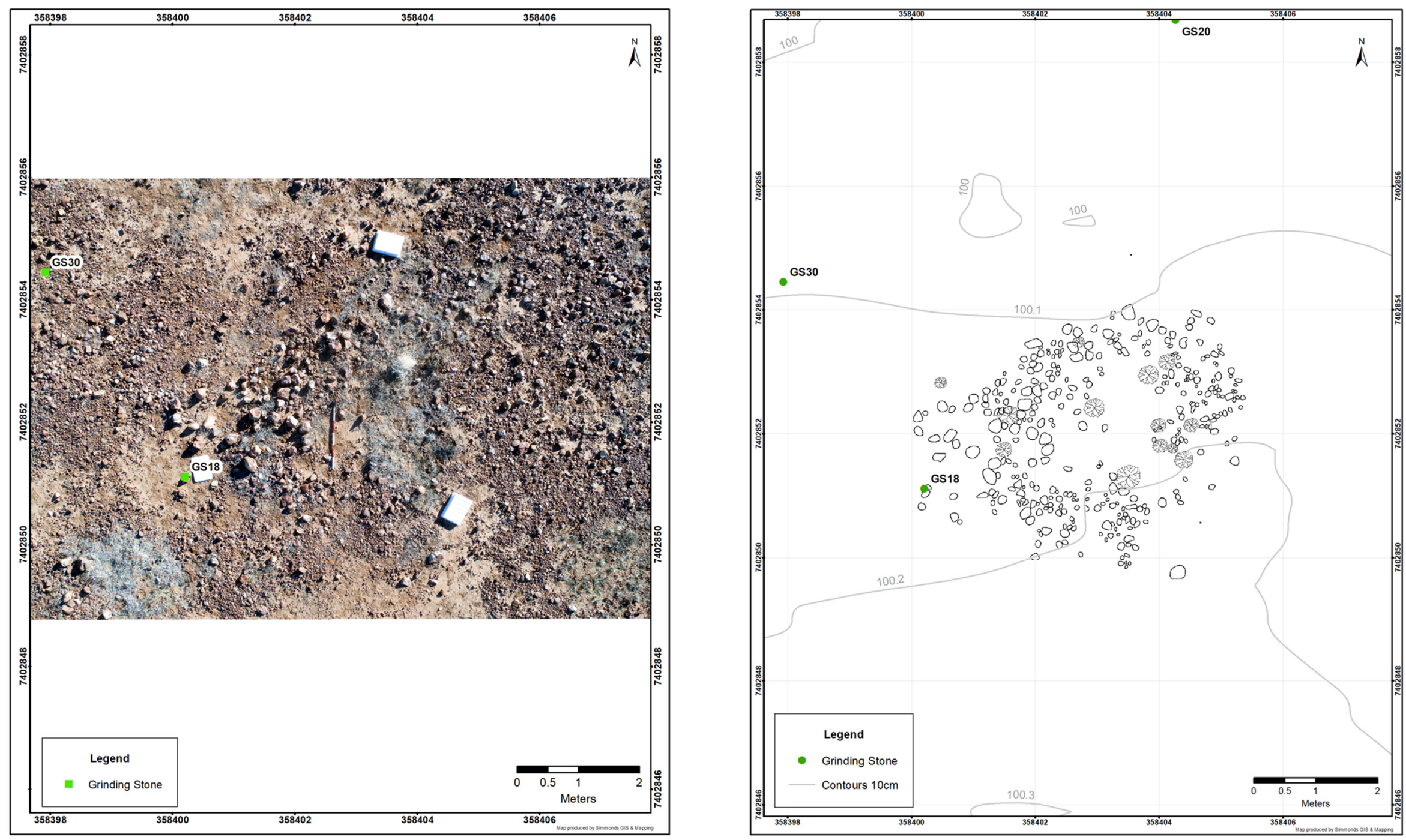

https://doi.org/10.25120/qar.24.2021.3799
Queensland Archaeological Research | Vol. 24 | 2021 | 37 
Appendix Q. Hut 13, HSC1.
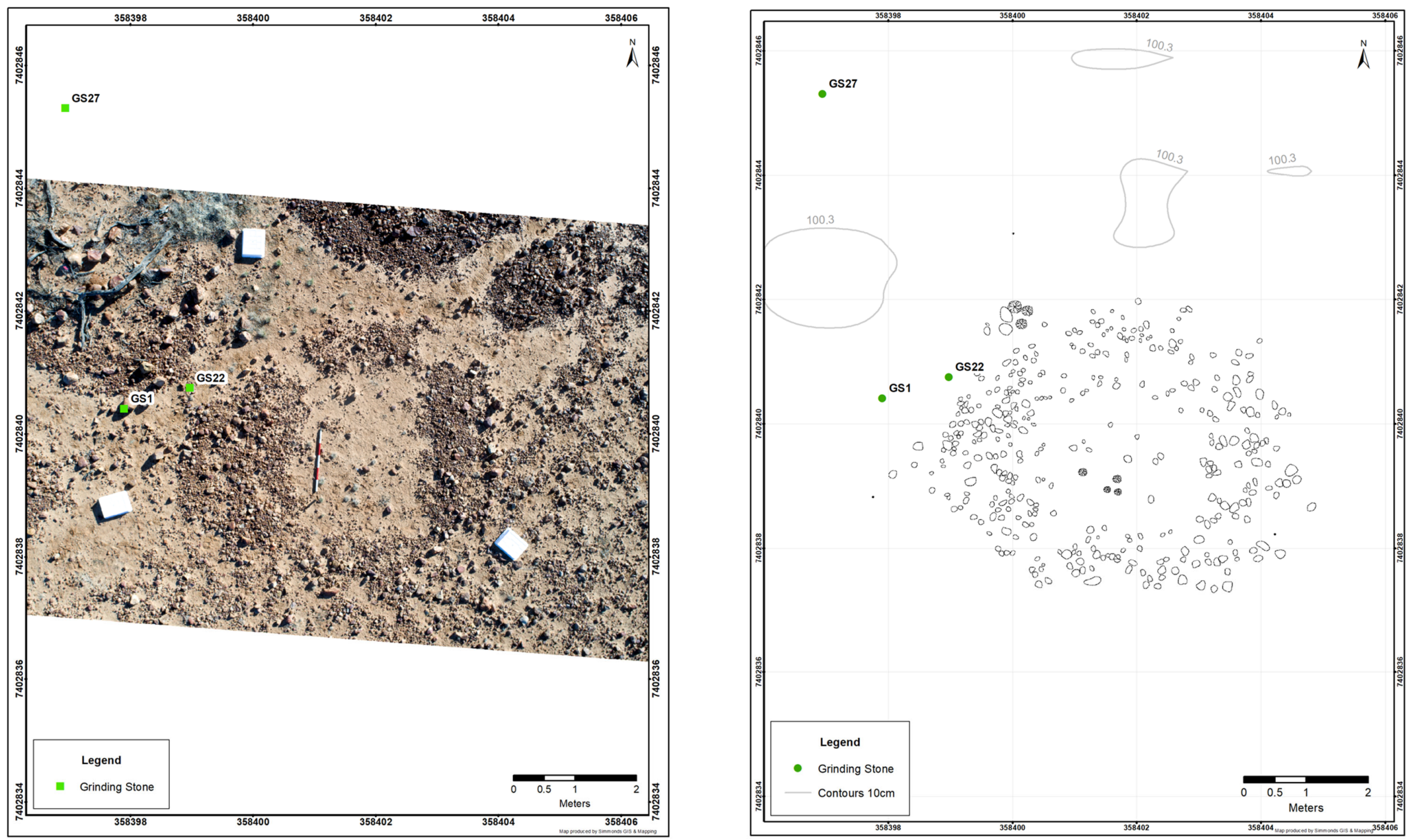
Appendix R. Huts 14 and 15, HSC1.

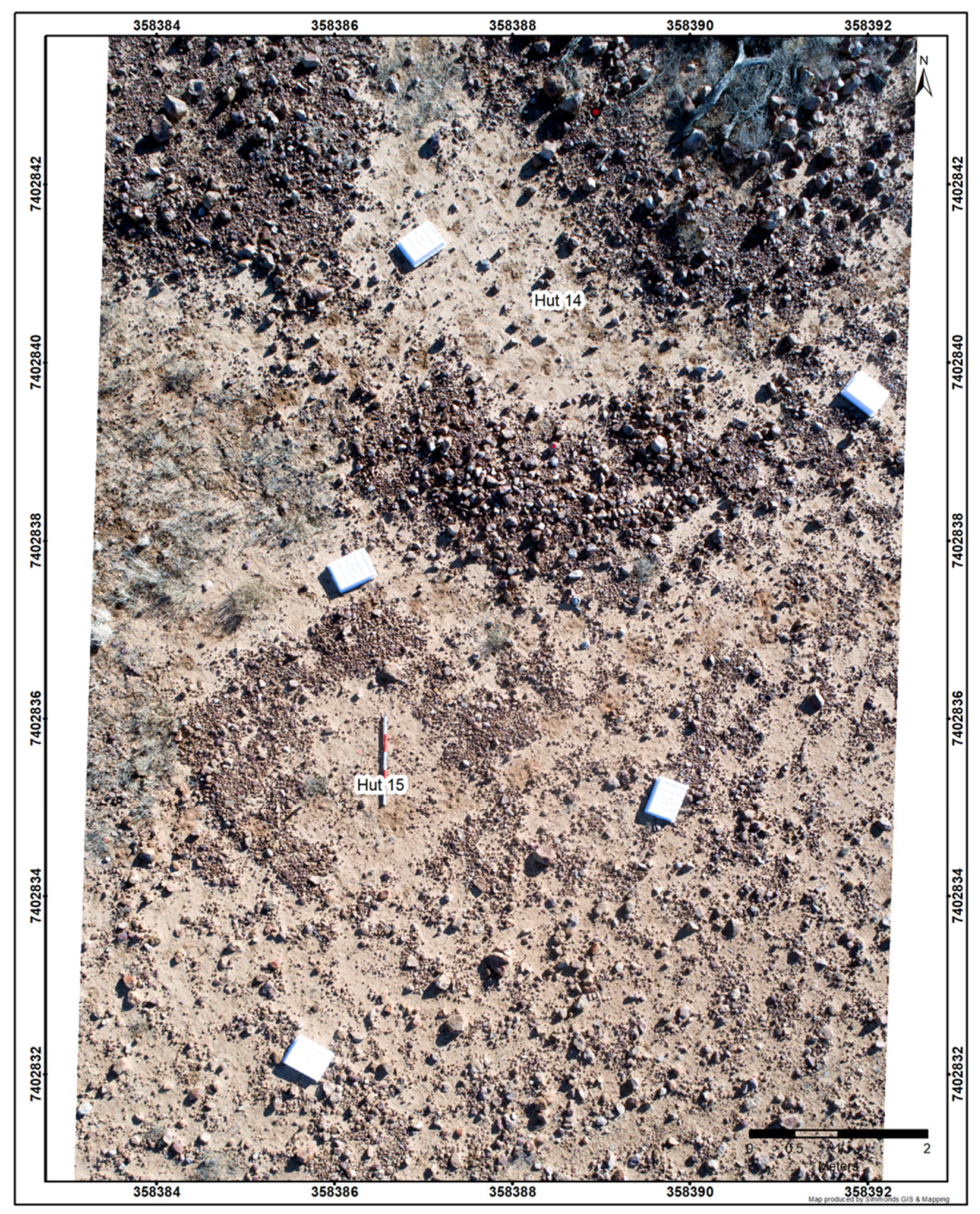

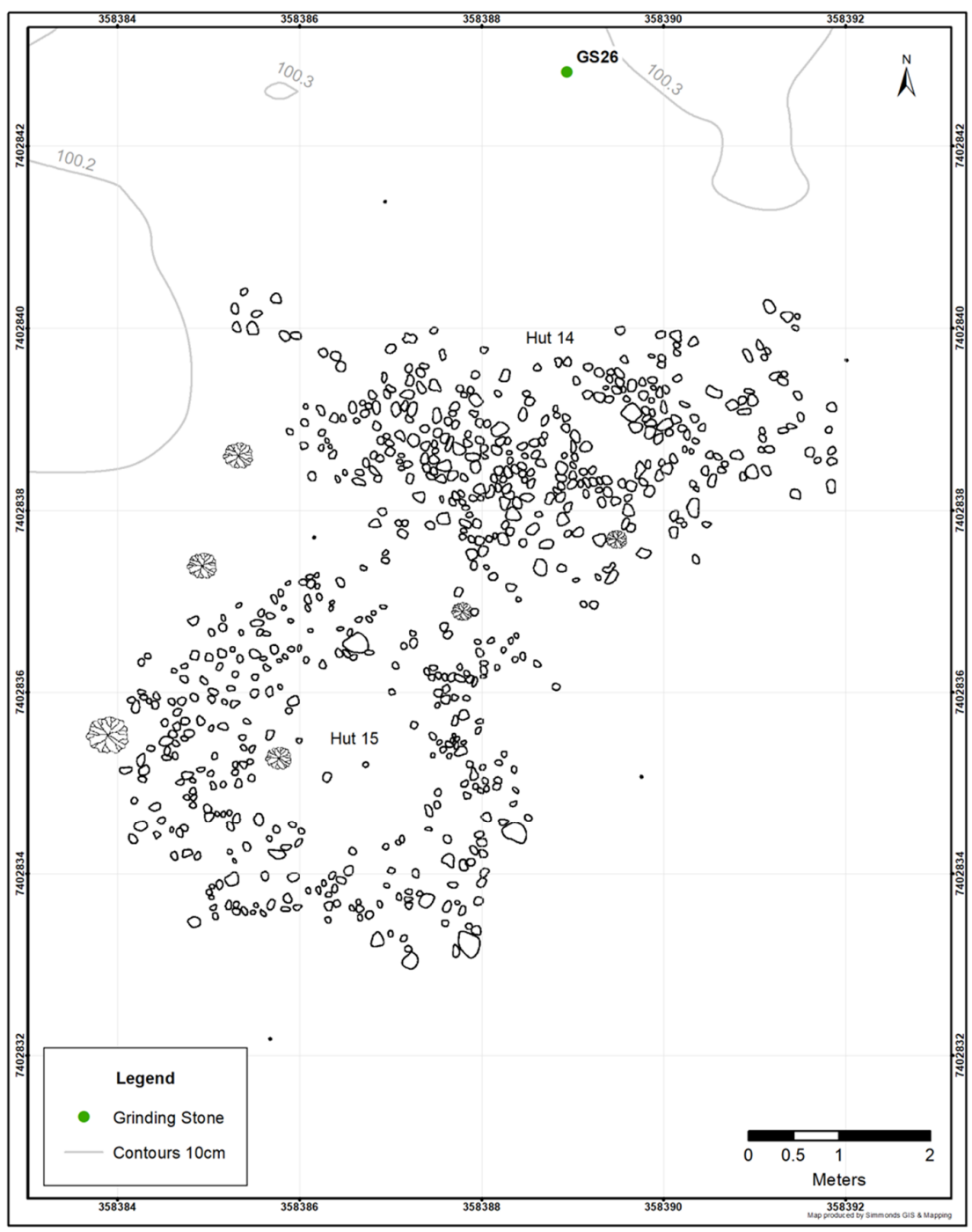


Appendix S. Hut 16, HSC1.

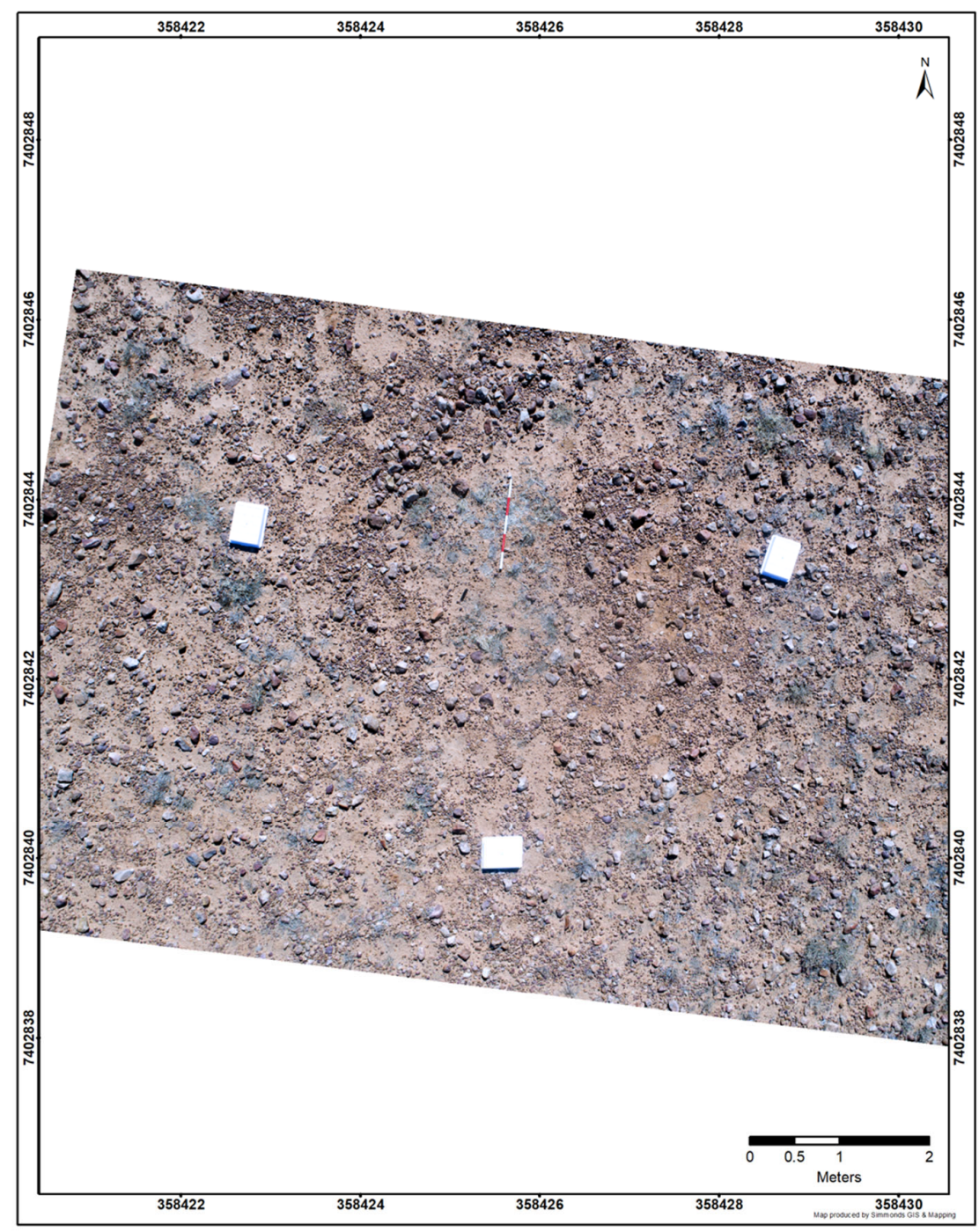

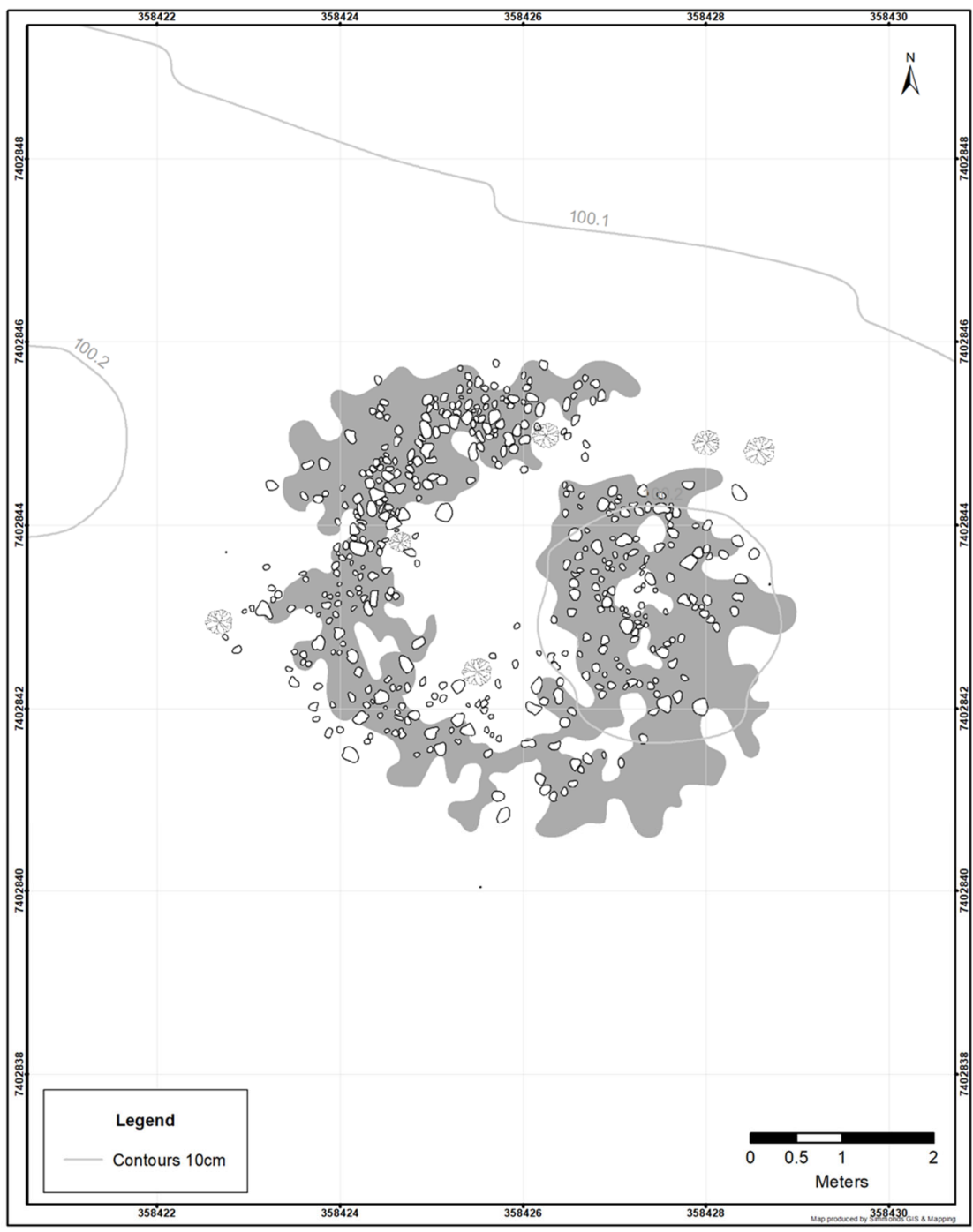


Appendix T. Stone arrangements 1 and 2, HSC2.

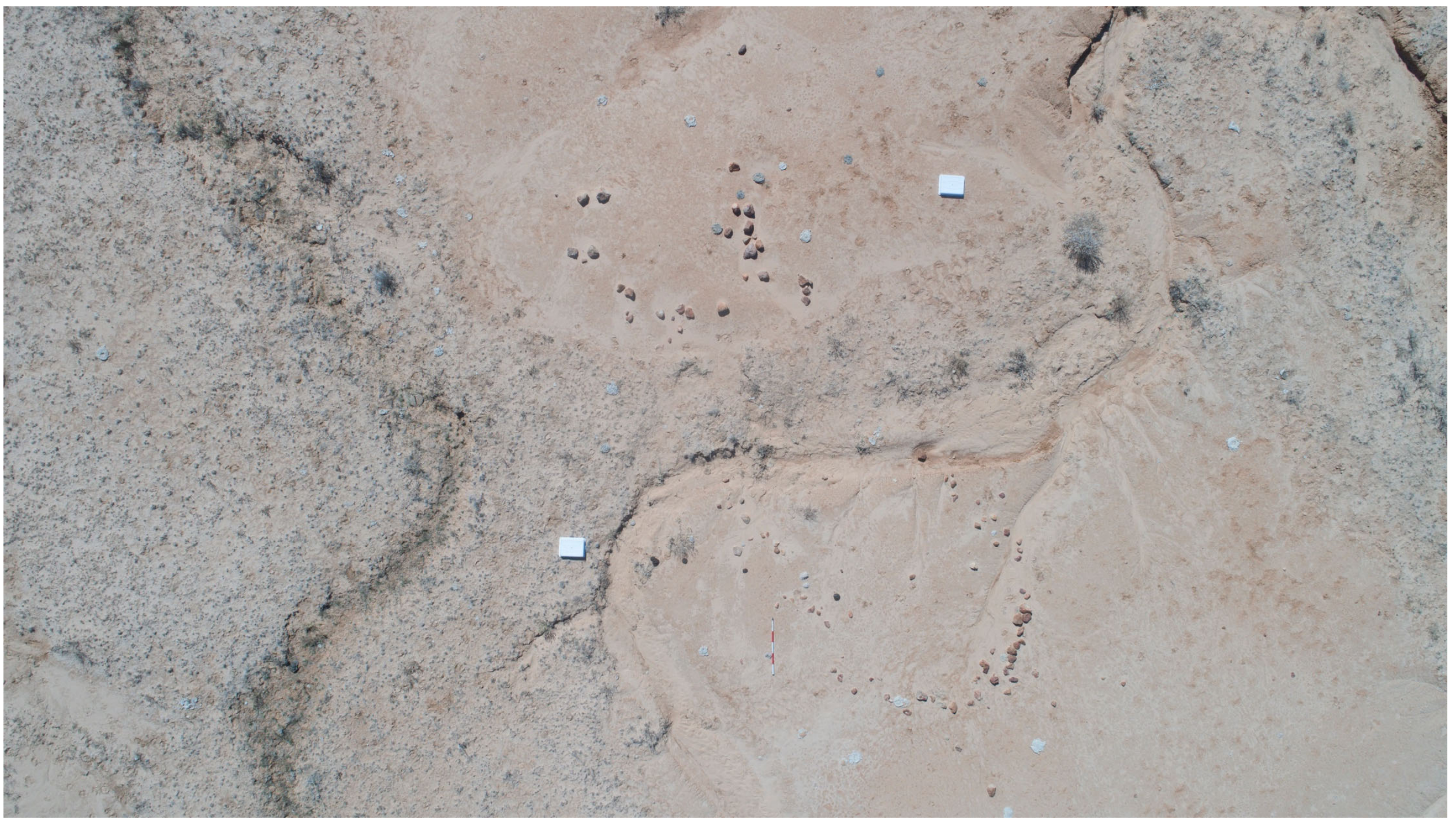


Appendix U. Stone arrangement 3, HSC2.

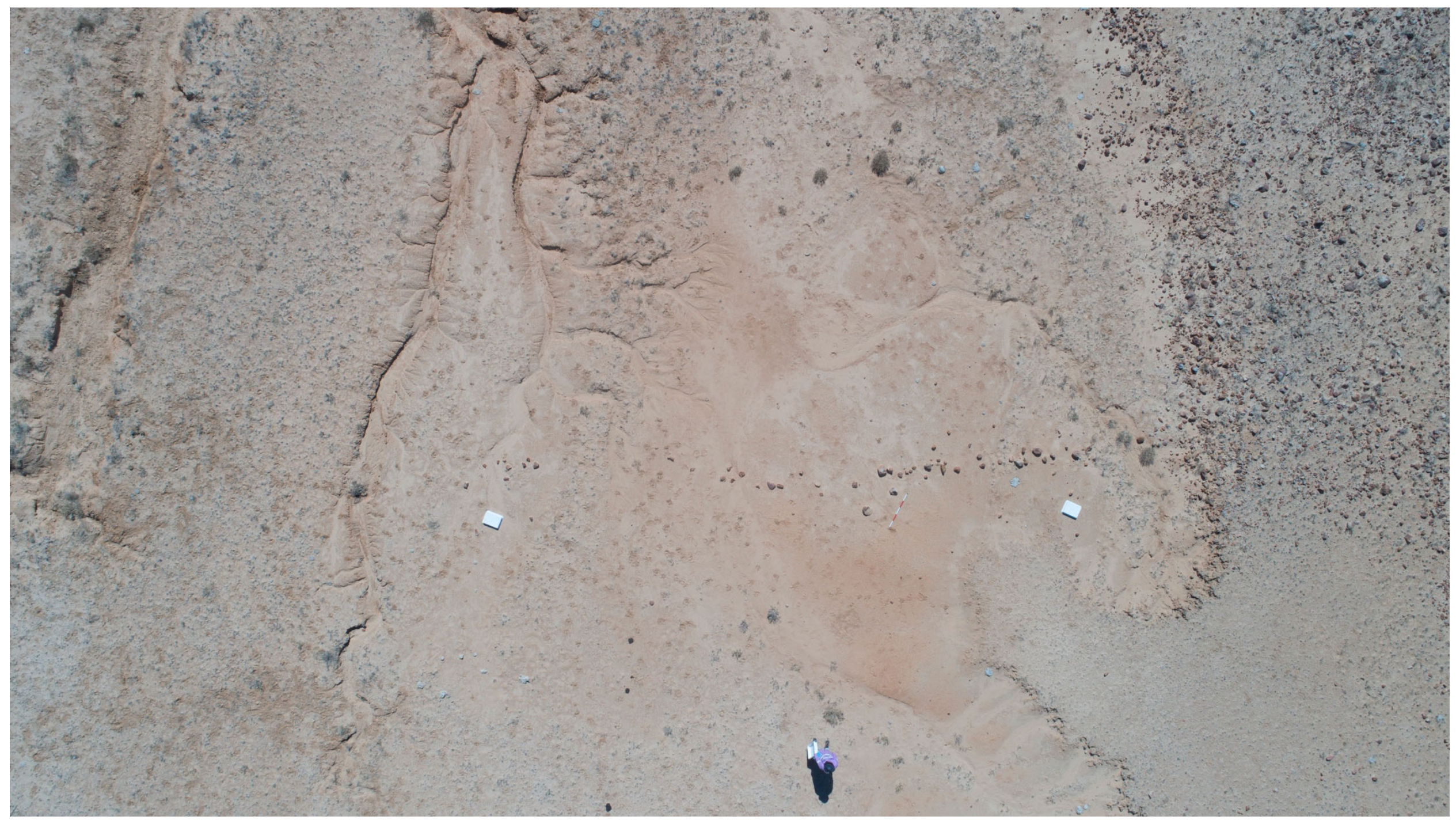


Appendix V. Stone arrangements 4 and 5, HSC2.

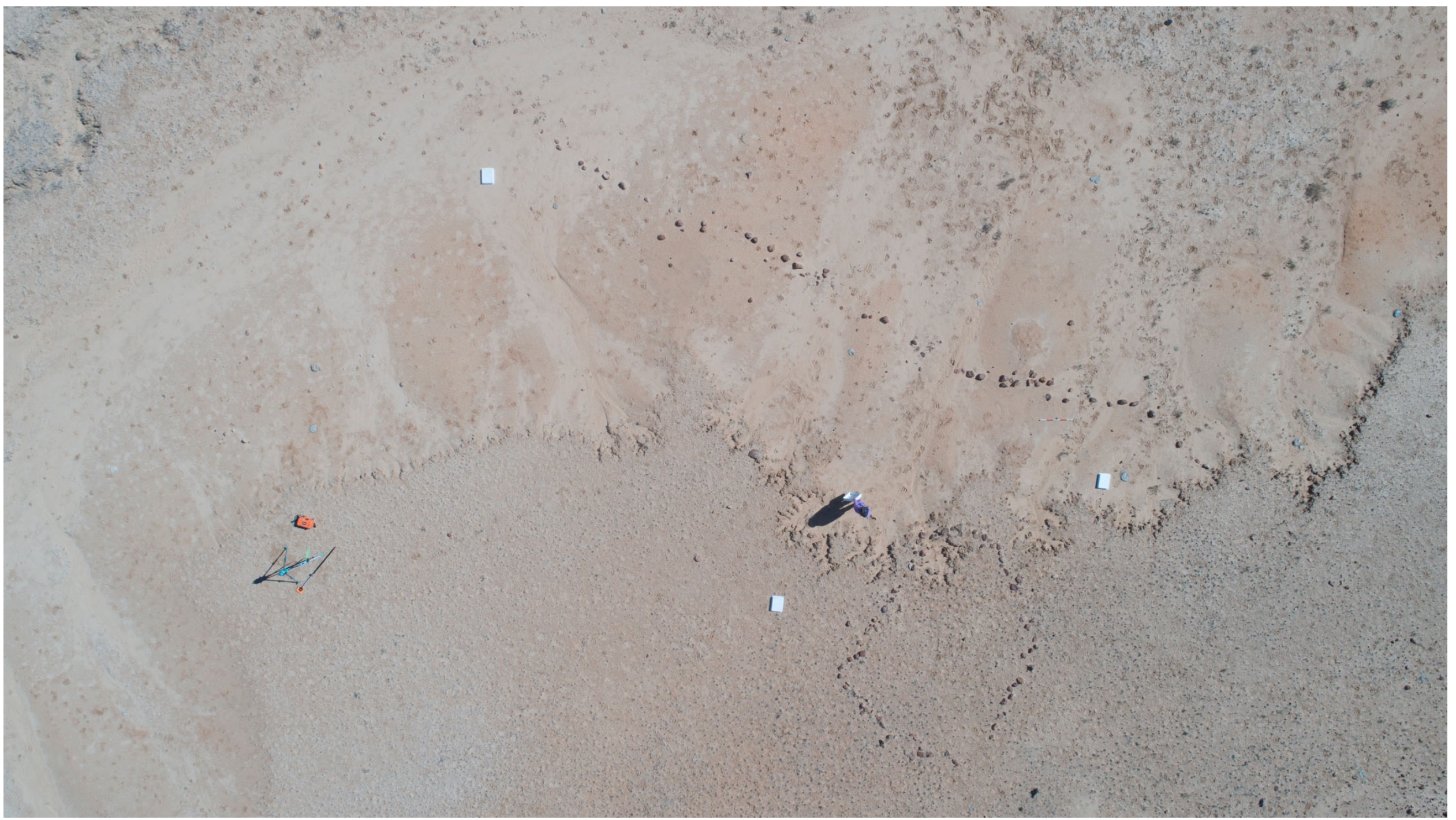


Appendix W. Stone arrangements 6 and 7, HSC2.

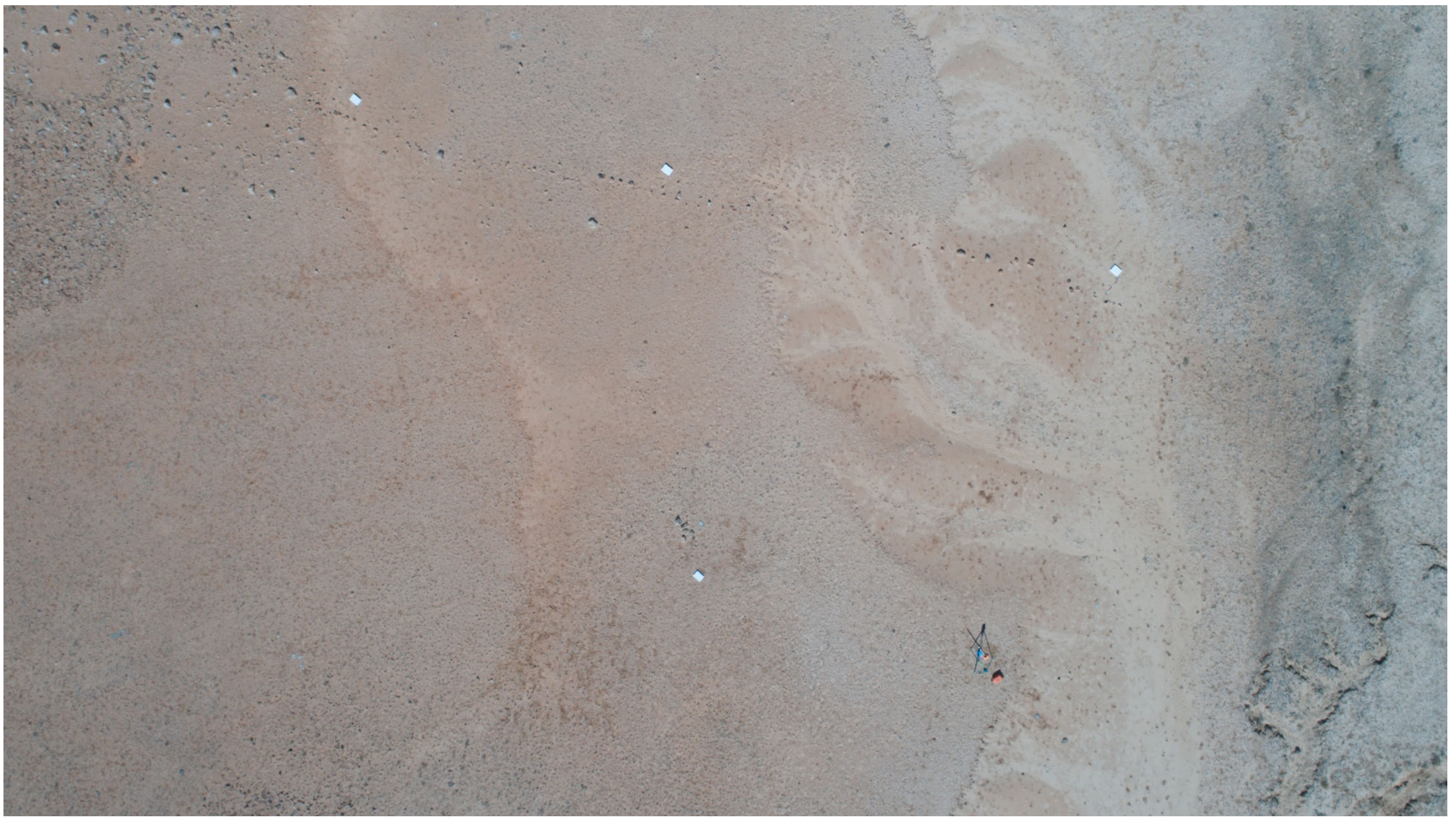


Appendix X. Stone arrangements 8 and 9, HSC2.

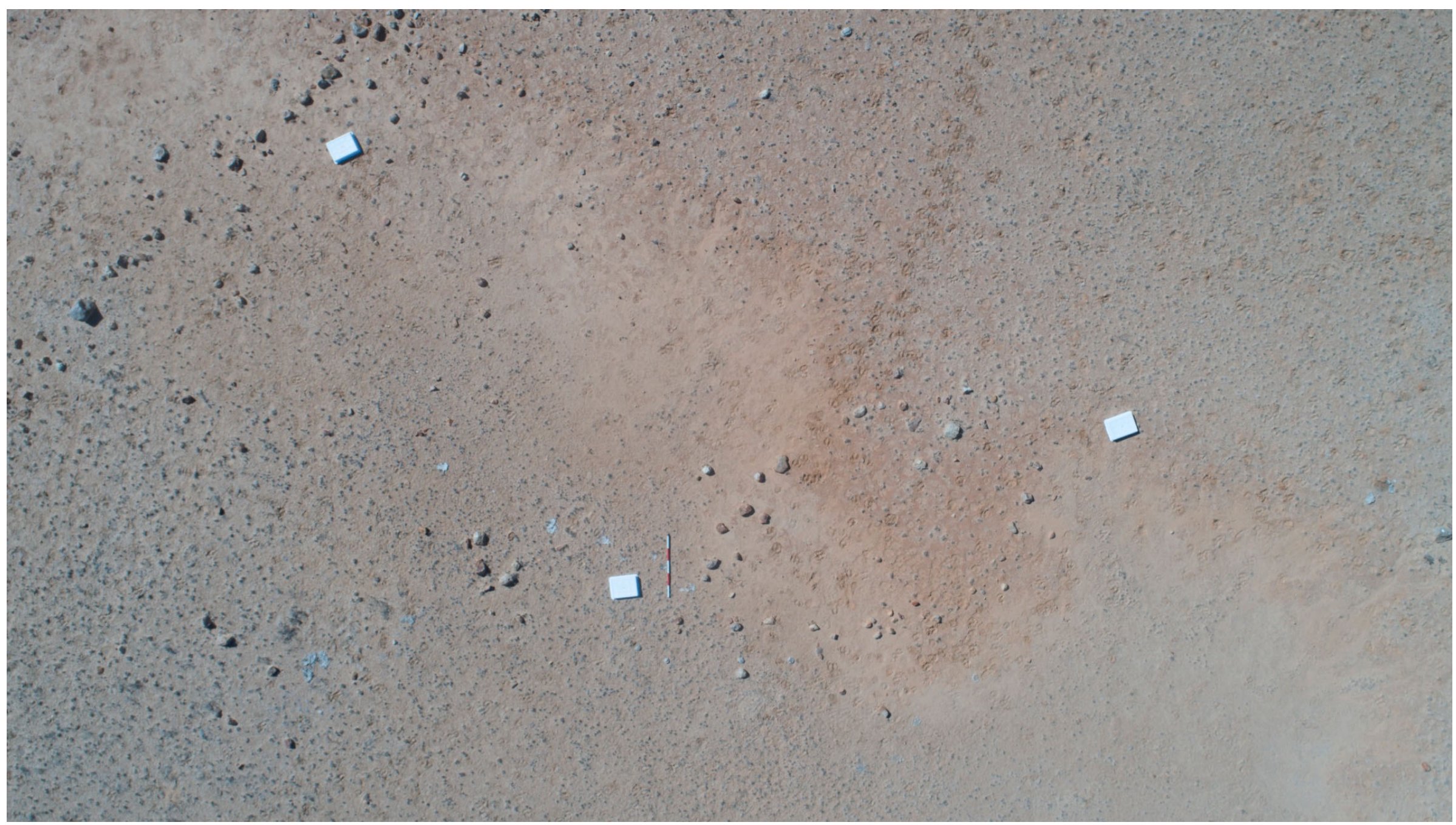


Appendix Y. Stone arrangement 10, HSC2.

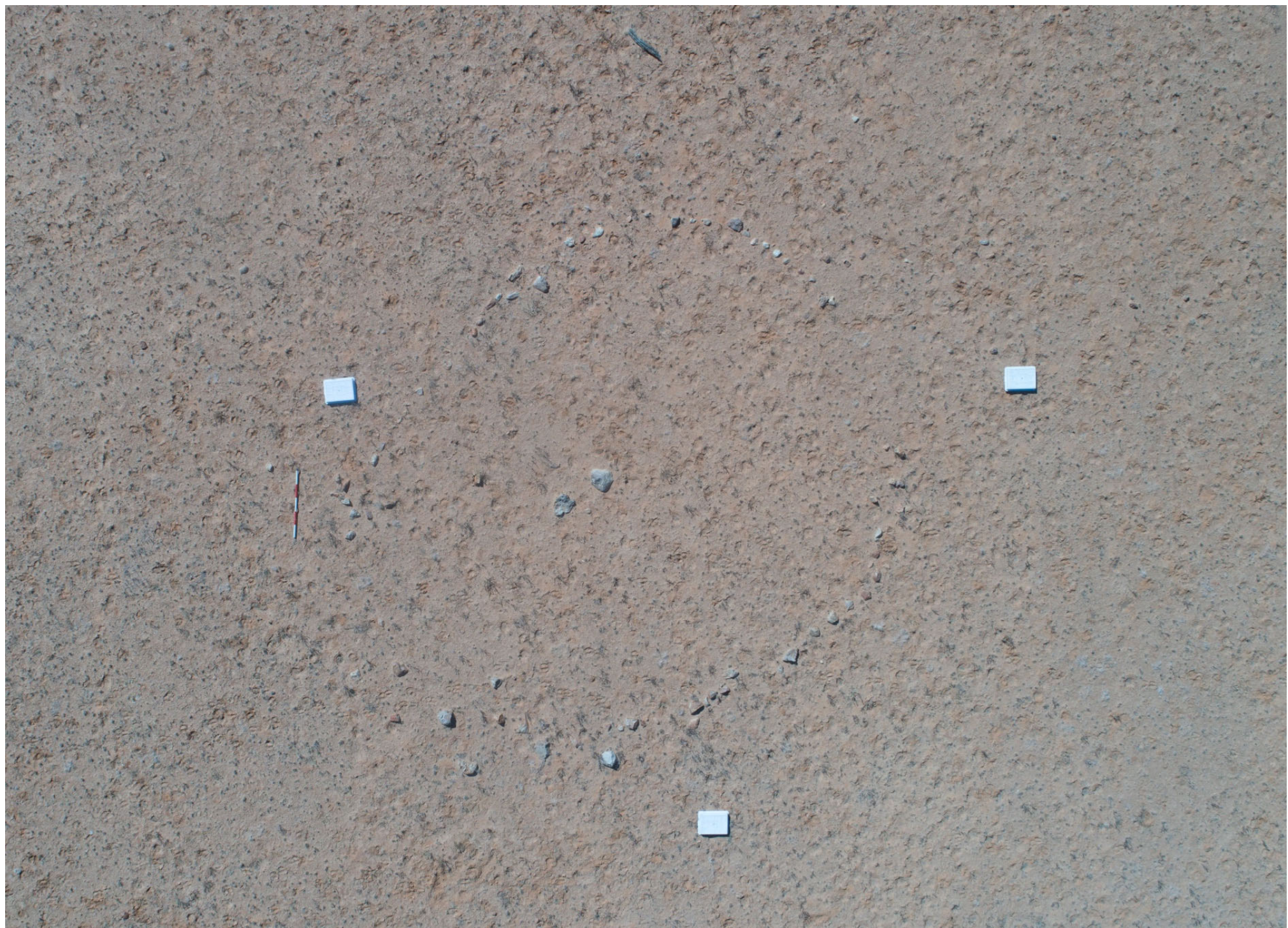


Appendix Z. Stone arrangement 11, HSC2.

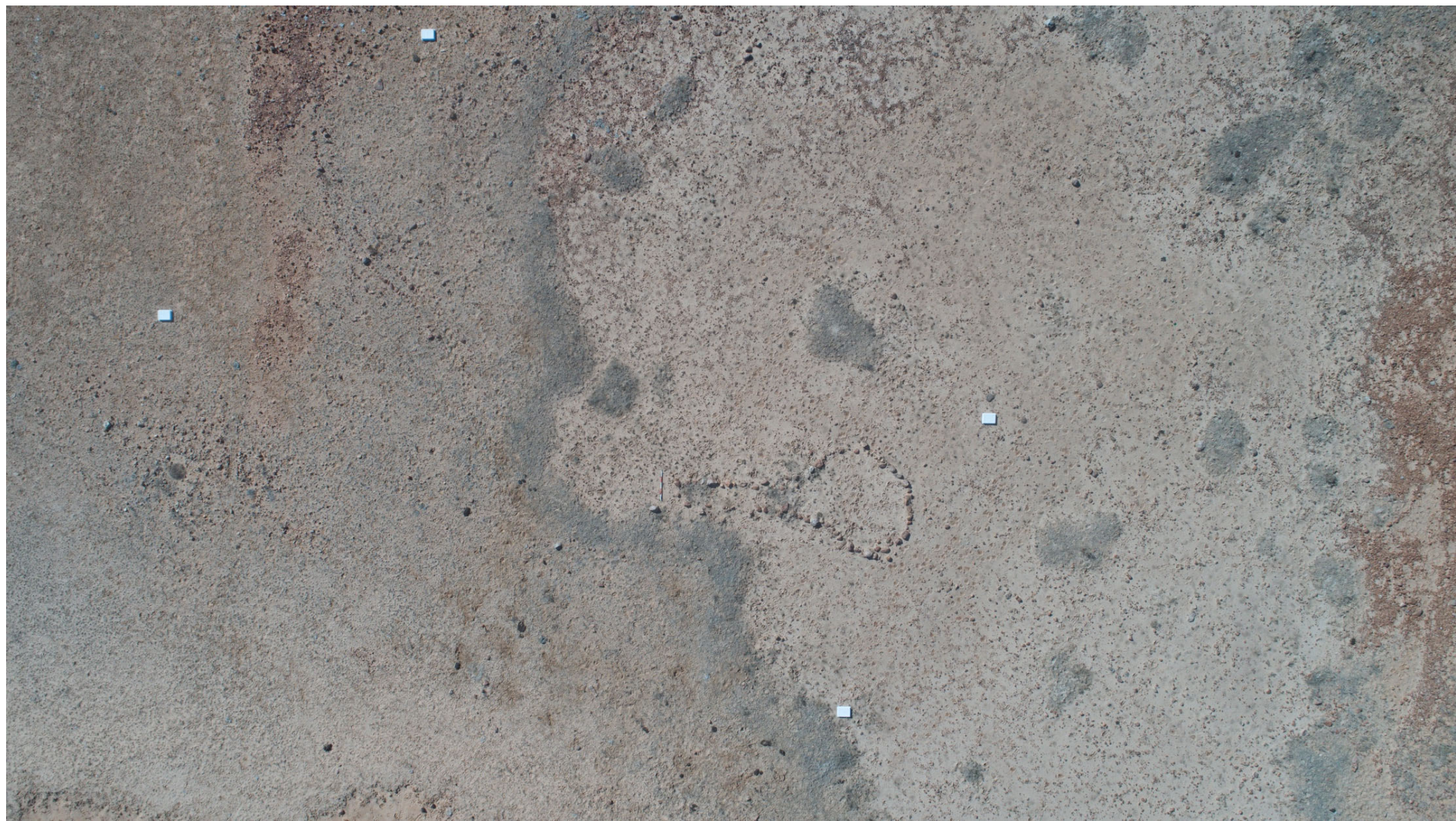

